Portland State University

PDXScholar

$1-1-2011$

\title{
"Art Feeling Grows" in Oregon : The Portland Art Association, 1892-1932
}

Patrick A. Forster

Portland State University

Follow this and additional works at: https://pdxscholar.library.pdx.edu/open_access_etds Let us know how access to this document benefits you.

\section{Recommended Citation}

Forster, Patrick A., "'Art Feeling Grows" in Oregon : The Portland Art Association, 1892-1932" (2011). Dissertations and Theses. Paper 220.

https://doi.org/10.15760/etd.220

This Thesis is brought to you for free and open access. It has been accepted for inclusion in Dissertations and Theses by an authorized administrator of PDXScholar. Please contact us if we can make this document more accessible: pdxscholar@pdx.edu. 
“Art Feeling Grows" in Oregon: The Portland Art Association, 1892-1932

by

Patrick A. Forster

A thesis submitted in partial fulfillment of the requirements for the degree of

\author{
Master of Arts \\ in \\ History
}

Thesis Committee:

David A. Horowitz, Chair

Richard H. Beyler

David A. Johnson

Sue Taylor

Portland State University

(C)2011 


\begin{abstract}
Founded in 1892, the Portland Art Association (PAA) served as Oregon's and the Pacific Northwest's leading visual arts institution for almost a century. While the Association formally dissolved in 1984, its legacy is felt strongly today in the work of its successor organizations, the Portland Art Museum and Pacific Northwest College of Art. Emerging during a period of considerable innovation in and fervent advocacy for the arts across America, the Association provided the organizational network and resources around which an energetic and diverse group of city leaders, civic reformers and philanthropists, as well as artists and art educators, coalesced. This thesis describes the collaboration among arts and civic advocates under the banner of aesthetic education during the Association's first four decades. Though art education continued to be critically important to the organization after 1932, the year the Association opened its new Museum, art was no longer conceived of as an instrument for improving general community life and programs focused on more specialized, fine arts-related activities.

During the PAA's early development, educational concerns trumped the accumulation of art objects, collection building, and the formation of a specialist arts institution that are typically associated with post-World War II art museums and art schools. I propose that the early Association is best understood as a community arts organization dedicated to the aesthetic education of the Portland community as a whole. I discuss the meaning of and goals set for the promotion
\end{abstract}


of art education within the Association, which issued from various, yet mutually supportive, positions. I describe Association programs as having been generally informed by prevailing ideas in art education, especially after the founding of its Art School in late 1909; art and art instruction were considered to involve an inherent moral dimension, civic improvement potential, and aesthetic value. Looking more closely at these assumptions, we can observe a shift in emphasis regarding the key purpose of art education programs at the PAA during the period discussed. Whereas the founding trustees generally harbored more idealized notions of art and placed aesthetic education primarily in the service of civic development and civilizatory achievement, professional educational concerns soon gained currency at the Association. To put it simply, this shift moved the focus of art's presumed moral resonance from the (external) identification of great masterworks and styles to the (internal) capacity for and recognition of authentic aesthetic experience.

Previous scholarship has considered early Association history primarily in light of its promotion, or neglect, of modernist art or of particular artists. I focus instead on the privileged position of art education and its organizational scaffolding in order to cast a different light on the growing Association and its supporting milieu. I suggest that the Association's championing of aesthetic education was part of an extraordinary emergence of competing ideas and organizations regarding the proper identity, purpose, and value of art and aesthetic education in America. Within that context, the PAA's energetic advocacy and diverse programs suggest a belief in art's 
capacity to improve individual lives and community bonds, a belief that is, however differently conceived, still closely held today. 


\section{Acknowledgments}

My curiosity about the history of the Portland Art Association was nourished by Sally Lawrence, President Emerita of Pacific Northwest College of Art. She insisted that an important story about the Association's early history, its influence on the region's arts community, and its eventual transformation into the Portland Art Museum and Pacific Northwest College of Art needed to be told. Furthermore, I am indebted to the excellent service and unfailing patience of Debra Royer, Librarian of the Portland Art Museum. She kept the Portland Art Association Archives available to researchers during the two-year period when the Library of the Portland Art Museum was closed and its collections were in storage due to building renovation. While I have come to share Ms. Lawrence's and Ms. Royer's enthusiasm for the earliest decades of the Portland Art Association and the organization's pivotal role in advancing the city's and the region's early arts community, any errors of fact and interpretation contained in this thesis are entirely mine. 


\section{Table of Contents}

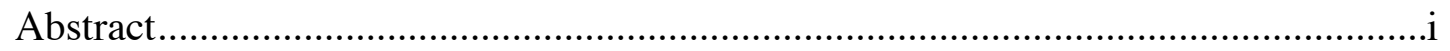

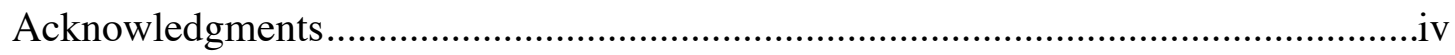

Chapter 1

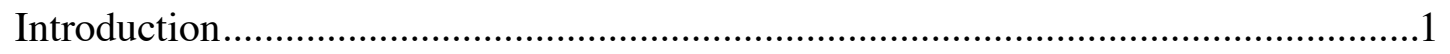

Chapter 2

Civic Visions: Founding the Portland Art Association in Progressive-Era America

Chapter 3

The Discriminating Eye: Elevating Taste in Art and in Craft..................................39

Chapter 4

The Portland Art Association and the Art School......................................................57

\section{Chapter 5}

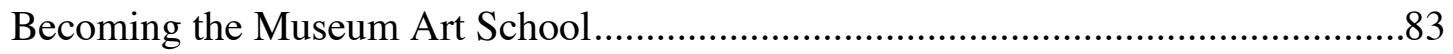

\section{Chapter 6}

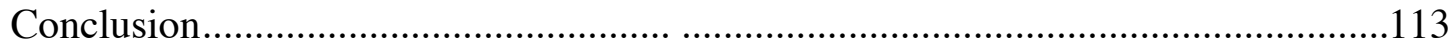

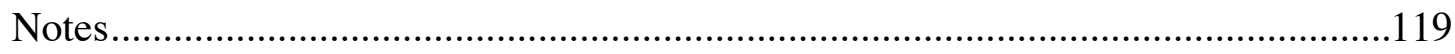

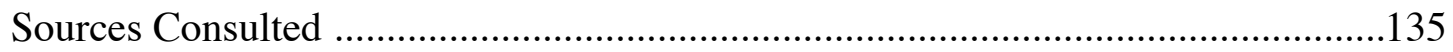




\section{Chapter 1: Introduction}

The founding of the Portland Art Association in 1892 marked Portland's and Oregon's most significant advocacy effort for the visual arts during that era. The Association deserves credit for creating and sustaining the region's two most prominent, influential and vital visual arts institutions of the twentieth century, the Portland Art Museum and the Pacific Northwest College of Art. At the time of its founding, however, visual arts activities and interests had at best a modest place in a rapidly growing but provincial city. Voluntary groups of artists and architects, annual agricultural and industrial expositions, and occasional painting workshops by visiting artists and limited patronage of their work by frugal local collectors characterized the scene. There was even an art gallery operating in Portland - but none of these activities enjoyed the support of city leaders or a solid level of institutionalization, let alone the attention of the general public. The founding of the PAA, however, signaled the start of a more ambitious and committed form of promotion of the visual arts. ${ }^{1}$

The Association and its activities quickly became a centerpiece of Portland's civic life that was second, if not equal, to the public library. In 1895 the PAA began holding art exhibits at that library; in 1905, the Association secured a museum building and, in the context of the Lewis and Clark Centennial Exposition, mounted an exhibit of modern artworks unprecedented in scope in the Pacific Northwest; in 1909 the organization started its Art School and a formal studio arts education program, arguably the most significant undertaking 
during the organization's earliest decades; by 1915, the Association managed extensive art docent and instruction services in Portland Public Schools; and by 1926, the Art School offered a five-year art teachers degree in collaboration with Reed College. Rachael Griffin, a long-time curator and instructor for the PAA, has suggested that, until well into the 1920s, the Association's "staff, students, members, and regular visitors were the art community [of Portland]." ${ }^{2}$ While art education and art appreciation enjoyed a privileged status, the size and quality of the organization's collection remained quite modest until the 1930s. With the building of a large modern museum facility in 1932 and the concurrent financial challenges by the Great Depression, the era of exuberant expectations and advocacy for the role of the arts and art education in the life and identity of the community came to a close. Though not a radical break with the Association's past, the 1930s brought a concentration on collection-based, fine art museum activities. The late-1940s opened the door to the expanding arena of undergraduate study and four-year degree completion. ${ }^{3}$

PAA sponsored programs to acquaint Portlanders with art objects from Western antiquity, European masterworks, non-Western artifacts, and, quite regularly after the opening of its school, modernist and even avant-garde artworks. Certainly, such endeavors built on notions of refinement and hierarchical cultural values. However, PAA leaders by no means viewed art as a domain open only to members of the social elite, wealthy collectors and connoisseurs, or the professional studio artist. Instead, art was associated with 
civic improvement and championed for its moral and spiritual potential rather than with conspicuous consumption. Association programs and resources were directed toward the Portland community as a whole, not just toward art specialists. By 1910, a PAA trustee could therefore boast with reason that "Portland is freely spoken of as in the lead among all the cities on the Coast in its equipment for Art Education." ${ }^{4}$

In recent years, centennial anniversaries of Portland art institutions and collections with direct or indirect roots in the Association have encouraged reflection, research, and publication on the history and relevance of local and regional arts, artists, and art organizations. In addition, questions about cultural agency and traditions, and artistic practice and standards, as well as newly invigorated claims as to the importance of the arts and creativity in individual and community lives, have inspired investigations into traditions and values of art and art education, locally and nationally. Recent scholarship on the Association and the early Portland arts community includes the work of art historians Prudence Roberts and Faith Emerson. Roberts has described the role of Association founders and the Association's first professional curator, Anna Belle Crocker, in shaping the organization's early exhibition and modest collection efforts. Emerson has explored the surprising presence of avant-garde artworks in the Association's exhibits in the 1910s and 1920s. Both Julia Hoffman, generous patron and first life-time trustee of the Association, and the Portland Arts and Crafts Society have been carefully described by historians Lawrence Kreisman 
and Glenn Mason in their history of the Arts and Crafts movement in the Pacific Northwest. Historian Richard Christen has critically examined the education and self-improvement imperative of Hoffman and of the Portland Arts and Crafts movement, which she promoted tirelessly throughout her life. Similarly, Ginny Allen's and Jody Klevit's Oregon Painters: The First Hundred Years 1859-1959 (1999), a comprehensive index and dictionary of Oregon artists and its institutional affiliations, adds details to the picture of the state of the arts and the PAA's crucial role in Progressive Era Portland. ${ }^{5}$

I began my research in order to provide an account of the "equipment" for art education that the Association introduced and supported during the era under consideration. I was surprised to find PAA publications replete with references to its educational and broadly community-minded endeavors, since these topics had thus far received little attention or critical review in writings and scholarship on the development of the visual arts and arts institutions in Portland. In fact, Emerson's study of exhibitions of avant-garde artworks at the Association's Museum closes with a call for an inquiry into the organization's educational mission, in part to illuminate the paradox of the promotion of avant-garde art by the PAA in a presumedly conservative community. ${ }^{6}$ Accordingly, I was excited to focus on this previously overlooked topic and thereby add a new element to the research that has been done on the PAA over the past decade.

I initially assumed my research would describe a relatively narrow range of educational programs, art studio pedagogies, and aesthetic values that we 
readily associate with those artworks which represent the period in the exhibitions and collections of art museums today. However, I soon realized that I needed to treat my account of educational activities as an Association imperative, not as an ancillary aspect of the organization's operations and growth in its earliest decades. The PAA not only dedicated resources primarily to education, but also insisted time and again that its educational goals served a broad public. We may not accept wholesale the populist rhetoric of early Association advocates, but the sheer number of such claims suggests that we should at least seek to reconstruct and critically review them.

I sought first to discover and describe the eclecticism and vitality of aesthetic and art educational thought in Progressive Era Portland and to place that description in the context of national developments. Hence, each chapter of this thesis recovers aspects of art education important in the historical context of my subject, but largely forgotten today, from populist motives in Progressive Era museum creation and operation to aesthetic and art education innovations by theorists such as Arthur Wesley Dow and Benedetto Croce. I am mindful of how much terminology and concepts in art and art educational have shifted over the course of the century. Not only have we witnessed a succession of different art objects and practices, but the very terms of what constitutes art have changed. While many of today's practices would have been meaningless to Association advocates a century ago, much of that era's concerns are missed if our 
interpretations are based on today's definitions and standards or simply on hindsight.

For example, the arena of professional art training a century ago has as many differences as similarities with today's post-secondary education practices, an issue pertinent to the founding of the Association's Art School. "In the early twentieth century, 'studio art' encompassed architectural design, painting, drawing, and urban planning," explains art historian Julia A. Sienkewicz. "Similarly, 'art history' included architectural history, the history of the built environment, and archaeology."7 Finally, art education's primacy in the PAA's early development is easily overlooked when the organization's first decades are seen merely as a pre-ordained path toward the institutional types of art museum and of art academy or college dominant in the American arts arena from midtwentieth century on. By suspending such teleology or "presentism," to use historian George Stocking's term, this thesis provides a more complex picture of the participants' ideas and motivations than would a study that measures the organizational development primarily against the - timely or delayed - arrival of modernist art practices and ideas. ${ }^{8}$

Extant scholarship on the early development of the Portland arts community emphasizes individual beliefs and action and, by and large, disregards organizational action. It does so for good reason. With no paid staff until the founding of its Art School in 1909 and limited endowment until the late 1920s, the PAA can be presented as little more than a volunteer association made 
up of a few cultural activists from the city's elite. From that point of view, the turn-of-the-century Association was mainly a mirror of individual advocacy for art, usually limited to a predilection for specific forms, such as the conservative style of the Barbizon School, the more up-to-date Impressionism, or the artisanal products from the Arts and Crafts Movement, and with little appetite for dispute. Anna Belle Crocker, the PAA's first employee and director, suggested as much in her memoir It Goes Deeper Than We Think: Reflections about the Role of Art in Education (1946). " "In contrast to the great world of art," Crocker mused in her typically metaphor-rich prose, "it was because the ground was unstirred rather than discomposed by conflicting elements, that breaks appeared in the opaqueness like frail stems pushing through thick earth."10

However, these historical accounts have not fully accounted for the role of the PAA in promoting art and art education for the general Portland community. Without attention to the Association, Portland arts advocates appear largely in isolation from one another and, hence, fit almost seamlessly into particular roles such as cultural conservative, civic leader, or art professional with avant-garde leanings. Yet a diverse set of individuals connected with one another through PAA membership and activities and made the organization into an effective platform for joint action. This was not simply a matter of personal preference; it also had significant organizational implications. For example, the Art School, founded in 1909, accommodated a diverse range of educational interests and purposes. Furthermore, the collaboration that occurred between 
advocates of seemingly irreconcilable cultural and aesthetic interests and values remains somewhat puzzling, even if one admits that the relative paucity of art resources in turn-of-the-century Portland fostered common action rather than specialist pursuits in the arts. After all, the Association did not simply connect individual art advocates and groups but also projected a surprisingly exuberant vision of the role of the arts in individual fulfillment and community life.

Consequently, I explore the role of the Association and its educational programs in their historical context rather than focusing more narrowly on those elements that can easily be associated with its successor institutions, the art museum and art college, and their successful institutional consolidation in postWorld War II America. Finally, the Association's broad endorsement of art education and art appreciation, as well as its related claims concerning art's moral capacity, have thus far been ignored - largely, I believe, because the very language, and certainly the idea, of art's presumed moral fiber strike many people as outmoded. Therefore, I inquire into the sources and rationales that supported such expansive views of art's and art education's goals and capacities rather than dismissing them as expressions of amateur ideas, unprofessional provincialism, or mere anachronism.

The founding of the Association and its early development followed a national upwelling of arts advocacy and of arts organization creation across the United States following the end of the Civil War. Indeed, historians commonly refer to the period as America's Museum Age. ${ }^{11}$ The new arts organizations and 
museums represented a wide range of initiatives and motivations, from local boosterism to community art clubs to collection assembling by the wealthiest Americans. Consequently, historian Nathaniel Burt has emphasized the institutional hybridity and eclecticism in the origins and development of American art galleries and museums. ${ }^{12}$ Within this diversity of beginnings, Burt has also identified populist sentiments and rhetoric among art and museum advocates, particularly in provincial, late-nineteenth-century cities such as Buffalo, Toledo, and St. Louis.

Arts advocates, civic leaders, and philanthropists in each of these cities took their cues from sanctioned practices at the nation's most prominent institutions, including Boston's Museum of Fine Art, New York's Metropolitan Museum of Art, and, to a lesser degree, the Art Institute of Chicago. Emulation was regularly limited, however, as the available wealth in metropolitan areas far exceeded that in provincial population centers. Provincial communities often insufficiently addressed, or even ignored, questions of sustained patronage in their efforts to raise civic spirits and the city's reputation. The arts and the art museum provided some of the most prominent icons in endeavors to create an American Athens and, according to historian Ingrid A. Steffensen-Bruce, represented an integral part of the City Beautiful movement. ${ }^{13}$

The PAA, too, considered and promoted art and aesthetic education as a matter of public interest. Importantly, these advocacy efforts were rooted in a democratic, if in some respects patronizing, commitment. The rhetoric of this 
advocacy was almost always steeped in popular appeal, which Burt has situated within the nineteenth-century tension between nativist and cosmopolitan cultural production, or as he states elsewhere, the conflict between "leather-stocking" and “silk-stocking" desires and ambitions. ${ }^{14}$ Ernest Francisco Fenollosa, early connoisseur of Japanese and Chinese art and curator at the Boston Museum of Fine Arts in the 1890s, summed up this goal of popular improvement and refinement in an 1896 article, "Art Museums and Their Relation to the People":

Art should therefore be the highest and most popular concern of the State. Art education in our public schools, in our civic life, is a duty we owe especially to the poor, the children of the laboring classes. It is for them that we found our art museums. ${ }^{15}$

Historian Nancy Einreinhofer has organized her comprehensive history of the American art museum around the tension between, and the differing institutional accommodations for, elite ambitions of art treasure collection and ownership on the one hand and populist goals of presenting and circulating artworks and art knowledge to a broad public on the other. In The American Art Museum. Elitism and Democracy (1997), Einreinhofer points out that the Metropolitan Museum of Art and the Boston Museum of Fine Art were founded on missions of moral betterment and education for all. ${ }^{16}$ Furthermore, Einreinhofer suggests that Progressive Era art and museum advocates, most prominently John Cotton Dana, championed popular educational programs at American art museums. Einreinhofer also reminds us that many innovative general audience programs at art museums were pioneered at American institutions in the early twentieth century..$^{17}$ 
The Association's articles of incorporation of 1892 listed as objectives the creation of a museum and of art collections for the study of art. However, the PAA did not single-mindedly pursue an agenda of collection building and art academy founding. Rather, the organization's early operations and mandate considered an audience well beyond conventional art museum and academic constituencies. Association programs as well as trustees and advocates strongly supported community activities, which were part of City Beautiful efforts and Progressive Era reform initiatives. These efforts connected arts advocates with one another, cultivated community audiences, and promoted the visual arts as instruments of civic and social development. PAA activities reflected reformminded and heterogeneous notions of art, civic uplift, and community life. Indeed, the Association's ability to accommodate different interests and communities within its organizational network as well as the varied arts and civic involvements of its trustees contributed to remarkable development and achievement in the visual arts, crafts, and community arts education in Portland during the first decades of the twentieth century.

This thesis, then, is the first attempt to represent the Association's early decades comprehensively. Various events in the Association's early decades have been previously documented; however, such accounts have focused on particular activities or individual leaders of the organization and presented these mostly in isolation. While they have recognized individual achievements, they have claimed or at least implied a sort of "against-the-odds" success for arts 
advocacy. In contrast, I suggest that the Association found a supportive and interested milieu for advancing a vigorous arts education program in Portland. Indeed, the PAA responded to a desire in provincial, turn-of-the-century Portland that was well within the national trend of founding arts and culture organizations. This descriptive and interpretive strategy toward telling the Association's early history illuminates an exciting chapter of American art education history that is typically eclipsed by the story of modern art and its famously successful museum institutions. The latter have provided us not only with the master narrative of modern artistic development, but have also furnished the iconography for modernist projects far beyond the visual arts. Yet the history of art education, as historian Donald Soucy points out, "still trails behind mainstream educational history." ${ }^{18}$ Study of the PAA's engagement with the most current ideas and leading individuals in the field sheds light on this fascinating and complex period of development in American art education. Association members corresponded with art education and art organization leaders and visited art education institutions nationally and internationally. In the PAA's first two decades alone, Charles Eliot Norton, Edward Robinson, John Dana Cotton, Frank DuMond, Arthur Wesley Dow, Ernest A. Batchelder, and Charles Robert Ashbee were consulted or brought to Portland to speak on current issues in art education and advise on organizational direction. Attention to these types of activities adds surprising complexity to previous scholarship on the development of the Association, which has viewed organizational activities primarily through an art 
historical lens and consequently has emphasized the organization's neglect of collection building and supposedly conservative aesthetic tastes.

Art education for a general audience was pursued throughout the early history of the PAA, even prior to the arrival of educational professionals. Not surprisingly, the organization's first paid staff positions were created for art educators in order to launch the Association's School in late 1909. Their leadership, especially Crocker's extraordinary directorship, would further strengthen and expand the Association's commitment to providing education programs for a broad Portland public. They would also connect the PAA and its programs with professional arts organizations, which wove an unprecedented national web of relationships and communication among the growing number of arts institutions and their professional leaders in the new century. Crocker's work and ideas are relevant not only because she led the Association for an extended period, but also because her positions are more accessible than those of other PAA participants due to the fact that she regularly surveyed and commented on organizational developments in the Association's publications.

My thesis draws significantly on Crocker's 1946 book, It Goes Deeper than We Think: Reflections about the Role of Art in Education. This remarkable self-published text is part organizational history of the PAA, part personal memoir, and part aesthetic manifesto. To date, Crocker's text has been mined for lofty-sounding quotes but has received little critical attention. I refer extensively to the text in part to illuminate the history of the Association and of Crocker's 
role. Her ruminations are particularly instructive because they were offered, to a significant degree, in defense of the educational prerogative in Association operations, which Crocker saw threatened locally and nationally. Thus, the text helps us reconstruct a discussion that took place on a national level in early twentieth-century America about the audience, purpose, and values of art education and museum work, issues Crocker passionately engaged with. ${ }^{19}$ Each of the following chapters covers roughly a decade in the Association's early development. Chapter 2 describes the founding of the organization, its original trustees and early members, and its connections with other Portland civic institutions. Chapter 3 describes subsequent Association efforts in securing a permanent building and connecting with contemporary work and ideas in the fine arts and the Arts and Crafts. Chapter 4 addresses the founding of the Association's Art School in 1909, certainly the pivotal and most consequential decision in the PAA's early history. Chapter 5 elaborates on the consolidation of Art School programs under the leadership of Crocker.

My thesis recognizes the Association's early decades as more than a transitional era of movement toward the eventual institutionalization of modernist art and post-secondary art education by mid-century. I describe a period of fervent belief in the transformational capacity of art experiences and attendant advocacy for art education for the public at large. In this respect, the thesis also draws on national developments in art institution building and art education, which illuminate the enthusiasm for general programs in art education 
at the PAA and in the larger Portland community. My investigation registers surprising vitality and diversity in American art advocacy and art education as I examine the ways in which the PAA served as a critical catalyst for a flowering of the arts in early twentieth-century Portland. 


\section{Chapter 2: Civic Visions.}

\section{Founding the Portland Art Association in Progressive Era America}

The spirit of the Museum Age swept through America in the closing decades of the nineteenth century. Unprecedented material prosperity, international commerce, and cosmopolitanism provided the basis for art collection and institution building. During the period, the nation's wealthiest industrialists acquired America's most significant art collections. Nathaniel Burt has referred to these industrialists as the "Great Titans" and suggests that their patronage and collections had a singular impact not just on the organization receiving their largesse, but on the development of the American art museum as an institutional type. Among them we recognize John Pierpont Morgan, benefactor of the Metropolitan Museum of Art, New York City; Andrew Carnegie, founder of the Carnegie Museum of Art, Pittsburg; Henry Clay Frick, founder of The Frick Collection, New York City; Andrew William Mellon, main donor to the National Gallery of Art, Washington D.C.; and John D. Rockefeller, whose son and daughter in-law contributed generously to the Metropolitan Museum of Art and the Museum of Modern Art, New York City. Other nationally prominent, affluent collectors and museum founders of the period include Albert Barnes, William Wilson Corcoran, Isabella Stewart Gardner, Leonard C. Hanna and William T. Walters. ${ }^{1}$

The typical single- or dominant-donor view of museum development a century ago has significant consequences for our understanding of the period: 
First, the focus on investments made by the very wealthy obscures the general enthusiasm for the arts and aesthetic education that prevailed at the time. Especially in provincial cities like Portland, St. Louis and Toledo, we observe what $\mathrm{H}$. Wayne Morgan identifies as a broadly based art public, with art and art organizations serving as instruments and symbols of civic and democratic pedigree. ${ }^{2}$ Secondly, connecting the growth of the American art museum primarily with donor bequests immediately implies a certain degree of political conservatism, especially when figures like Morgan or Mellon are involved. This in turn makes it difficult to recognize any motives other than conservative ones behind the period's institution-building efforts in general. Noblesse oblige, so art historian Robert Hughes, led to "the creation of libraries, schools, university colleges, concert halls, parks, museums, and other amenities, which would inspire gratitude in the laboring masses and defuse their resentments, while creating around their donors the aura of Maecenas."3 Finally, an emphasis on the interestedness of political and economic elites obfuscates the surprisingly strong and popular belief in art's power to improve individual and community lives held by many a century ago.

Wealth and political power certainly were prerequisites for any arts and museum-related endeavor. The Portland Art Association's founding trustees represented Portland's oldest and wealthiest families and were politically and economically well connected. All of them collected artworks and objets d'art more or less seriously, even if with much smaller investments than the collectors 
referred to above. Most of them had previously pursued joint business or philanthropic endeavors. As Portland's leaders, they were well informed about cultural and civic developments in Eastern cities as well as in provincial population centers throughout the country.

This chapter describes the first decade of the PAA, during which the organization secured a collection of reproductions of Western canonical artworks and exhibition space in Portland's Public Library, both managed by volunteer curator, Henrietta Henderson Failing, niece of founding trustee Henry Failing. Within little more than a decade the Association had established a center for the city's cultural life with advocacy for popular art education and appreciation at the center of the organization's mission.

Above all, this chapter seeks to illuminate the popular aspects of the Association's appeal and motivations, aspects that are easily overlooked when art museum founding is considered a hegemonic project serving narrow class interests. I do not suggest that Association activities were disinterested or marked by cultural and political egalitarianism. However, in creating the Association, the group laid the foundation for an arts institution that was meant to boost civic pride and to enhance the reputation of the rapidly growing, provincial city. At no point was the Association an arena for the public flaunting of art objects and for the conspicuous display of wealth by the Portland elite. Despite varied tastes and levels of interest in art, the PAA's founding trustees considered art objects and their study important and elevating. They did so, however, not for mere historical 
or formal learnedness in artistic matters. Art study for art study's sake was not sufficient. Rather, the Association's activities sought to awaken the aesthetic sensibilities of Portland citizens and raise the standards of aesthetic refinement in the urban community. Hence, they were, as Anna Belle Crocker described, "active as well about education and about art itself as they saw it."

The founding trustees shared a vision of art as an instrument for genteel refinement and civic development. An early Association bulletin expressed this purpose clearly: "A public museum of fine arts offers the whole people an unfailing source of happiness, enlightenment and edification." ${ }^{5}$ Such a notion was not a mark of provincialism but was well within the trend of art advocacy and aesthetic study elsewhere in the nation. In her study of art museums and American culture at the turn of the century, art historian Ingrid Steffensen-Bruce describes the civic impulse typical for the time as follows:

[T] he art museum could uplift the urban denizen both morally and spiritually through the educational influence of the art it contained, as well as through the physical appearance of a well designed museum building. As art institution and as architecture, the art museum was both a practical device and a hopeful symbol to the turn-of-the-century interest in urban improvement. ${ }^{6}$

Leading Eastern institutions such as Boston's Museum of Fine Art and New York's Metropolitan Museum of Art sanctioned this type of organization and the practice of object study. Portland's efforts emulated the metropolitan standards, even if the local efforts were necessarily smaller in scope given the more modest size of the community and of the accumulated wealth. In type and 
scope, the PAA initiative resembled those under way in other provincial cities at the time including Cincinnati, Cleveland, Saint Louis and Toledo.

Seven prominent Portland citizens signed the Association's articles of incorporation on December 12, 1892. The group included Winslow. B. Ayer, lumber businessman; Henry W. Corbett, banker, merchant, and U.S. senator from 1867-1873; Thomas L. Eliot, minister of the First Unitarian Church; Henry Failing, real estate developer; William Mead Ladd, banker; Holt C. Wilson, physician; and C. E.S. Wood, attorney, painter, and poet. ${ }^{7}$ The most influential and wealthiest among them were Corbett, Failing and Ladd, each the patriarch of a venerable Portland family. The group shared family ties and many investment projects, from land and real estate holdings to private waterworks and commercial enterprises. ${ }^{8}$ In his chronicle of Portland's elite at the close of the nineteenth century, Paul Merriam identified "the Failing-Ladd-Corbett axis" as the most influential family group. ${ }^{9}$

The catalogue for the Association's fiftieth anniversary exhibition provided the following description of its founders and praised their efforts in creating and foresight in sustaining the organization:

As a body this group was conservative, objective, intelligent and supremely devoted. As individuals each gave some particular gift of personality that was invaluable in the task for which the Board was responsible. Mr. Ayer's executive ability, his power to get things moving, and his keen interest in quality; Mr. Ladd's personal interest in art that led him to make his fine collection of etchings and Japanese prints; Dr Eliot's broad human approach and his unfailing support of liberal education; Dr Wilson's love of painting; Mr. C.E.S. Wood's individual gifts and his extensive friendships with New York men of art - these and the feminine good sense, taste and human interest of Miss Henrietta E. Failing. ${ }^{10}$ 
Crocker confirmed that among the PAA's earliest supporters a sentiment of self-assuredness and conservatism in matters of taste and culture prevailed. She admitted that such interest frequently had to be guided - as was no doubt the case with trustee Corbett, whom she at one point described as "quite lacking in esthetic feeling or understanding." "11 Yet, Crocker held that PAA members and supporters made independent decisions and were impervious to external and superficial factors when making aesthetic commitments and judgments. Crocker described the trustees as entirely uninfluenced by any notion of art as "a vaguely conceived 'something every city should have'; a luxury or a servant to personal vanity; a place of amusement or an illustrated newspaper reporting what goes on in art; or a decorous circus 'for the people."12

The articles of incorporation of 1892 set forth the Association's mission as follows:

The object, business and pursuit of this corporation shall be to make a collection of works of art and to erect and maintain a suitable building in which the same may be studied and exhibited; to develop and to encourage the study of art and receive gifts and bequests of works of art, money, real and personal property for the uses of the Association. ${ }^{13}$

Such phrasing was similar to the founding mission statement of the Metropolitan Art Museum, which referred to "encouraging and developing the study of the fine arts [and] advancing the general knowledge of kindred spirits, and, to that end, of furnishing popular instruction and recreation."14

The Association's initial action was to secure the first objects of its art collection. Interestingly, these first and, for more than a decade, only acquisitions 
were all reproductions. They included a collection of photographic prints of European masterworks, purchased in 1893, and an extensive group of plaster casts of Greek and Roman sculptures and friezes acquired two years later. Through their connections and service, the trustees secured exhibition space at the new Portland Library building.

The desire for civic reform, institution-building, and economic development brought together a broad coalition, including representatives and officials of the City Board of Charities, the Portland Library Association, the Portland Park Commission, the Boys \& Girls Aid Society of Oregon, the Y.M.C.A, and the 1905 Lewis and Clark Centennial and American Pacific Exposition and Oriental Fair (Lewis and Clark Centennial Exposition). Trustee involvement in the Exposition was not limited to financial goals but also reflected attitudes typical of the City Beautiful movement. Founding trustee and Unitarian minister Thomas Lamb Eliot led the eventually unsuccessful effort to use the Exposition preparations for the development of a vision of Portland of future generations. It was at Eliot's invitation that John Olmsted, nephew and adopted son of Frederick Law Olmsted, came to Portland to develop an Exposition plan, which was to serve as a blueprint for guiding Portland's urban development in future decades. ${ }^{15}$ In his definitive study of the City Beautiful Movement, William H. Wilson describes the period's ideals and fervor as “a cultural agenda, a middle-class environmentalism, and aesthetics expressed as beauty, order, system, and harmony to influence the heart, mind, and purse of the 
citizen. ${ }^{\prime 16}$ The context of a broader civic enterprise is important to our understanding of the PAA's founding for several reasons: Association trustees pursued a community-wide audience, not a narrowly prescribed group of art specialists. Similarly, aesthetic education at the organization was privileged over a particular aesthetic program. Finally, the PAA trustees attributed a moral dimension to the visual arts and conceived of aesthetic education as an instrument of social uplift.

The choice of plaster copies of antique sculptures highlighted the civic ambitions of the Association as well as what was then recognized as an expression of the unity of artistic and civic life. The plaster copies were made from molds of the original sculptures in museum collections in England, France, Germany and Italy. The Association selected a total of 93 casts for its collection, including copies of the Apollo Belvedere, the Laocoön, Hermes of Praxiteles, the Venus of Medici, and the Venus of Melos. Corbett mused that the casts represented "an expression of civilization and life of the people from the past and from far away lands. ${ }^{\prime 17}$ It came at a considerable cost to the founding trustees and supporters. With Corbett giving $\$ 10,000$ and raising another $\$ 40,000$ from wealthy Portland families, the casts were referred to as the Corbett Collection. No other financial donation of this size toward the acquisition of art objects would be made to the Association for three decades to come. ${ }^{18}$

To today's art museum visitor, this collection of casts seems an unusual choice of first objects. To be sure, an authenticated original would be a highly 
prized object, but not a plaster copy. Given the century-long triumph of the American art museum and the privileged position originals now have over reproductions, it is surprising that an art organization, especially one claiming to provide a museum function, would have acquired these copies at such significant expense. In fact, the Association would not acquire a single original artwork until close to the end of its second decade of operation. However, the PAA made the purchase of the casts in the decade when this art collection practice peaked in the United States. Leading museum institutions, such as the Boston Museum of Fine Art, the Metropolitan Museum of Art, the Corcoran Gallery of Art, and the Art Institute of Chicago, all had significant plaster cast collections (although their holdings were not limited to such casts, as was the case at the PAA). Boston, in fact, boasted the world's third largest plaster cast collection, with larger collections only to be found in Berlin and Strasbourg. Finally, cast collections were also prominently featured in the new arts institutions from the midnineteenth century on. For example, London's South Kensington Museum, the center for various art education reforms in the late nineteenth century, purchased its collection at the Crystal Palace Exhibition of $1851 .{ }^{19}$

The Association carried out its investigation and acquisition in consultation with leading experts at these institutions. In preparing for the purchase, founding trustee Ayer corresponded with and eventually visited Eastern and European experts on and manufacturers of casts. Ayer consulted with Charles Eliot Norton, the first professor of art history at Harvard University; 
Ernest F. Fenollosa, scholar and curator at the Boston Museum of Fine Art; and Edward Robinson of the Boston Museum of Fine Art between 1893 and 1895. Robinson was an international authority on the subject and served as advisor to significant cast acquisitions by the Metropolitan Museum and the Slater Memorial Museum in Norwich, Connecticut. He authored catalogues on the cast collection of Boston's Museum of Fine Art in 1891 and 1896. In a letter from late 1894 to Ayer, Robinson commended the Association's selection of reproductions as a "a splendid beginning for your collection."20

In 1897, the PAA published a catalogue describing its own collection of casts that quoted extensively from Robinson's 1896 catalogue for the cast collection of Boston's Museum of Fine Art. Richard Norton, son of Charles Eliot Norton and professor of art and archaeology at Bryn Mawr, provided a scholarly introduction as well as entries on the Association's "unique" plaster casts. Norton's introduction exemplified the idealized, morally grounded conception of art, which resonated with much of the PAA's trustees and artistic community at large. Norton's essay elaborated a presumed distinction between art and aesthetic perception on the one hand and "a mere mental sensualism" on the other and argued that a genuine work of art always represented "an emotion that intensifies life." ${ }^{21}$ Thus Norton claimed a privileged status for true aesthetic experiences and attributed significant this-worldly value to them. Even if true artistic genius was given to only a few, art appreciation and aesthetic sensibility could be taught to the general public and thereby improve standards of aesthetic appreciation in the 
community at large. In fact, general aesthetic education was of great importance not just because it taught individuals to identify artistic forms and quality correctly; but also because it prepared citizens for the appreciation and recognition of what presumably represented the character of civilizations and nations. According to this notion, the study of art provided a privileged understanding of human affairs and civilizations. In Norton's telling, collective artistic achievements were deeply connected with the social and political order of a people. Hence, aesthetic education and discrimination were not simply a state of mind, a private experience, but a matter of social order and harmony. The possession and display of the replicas of antique sculpture can thus be described as a process of "heritage in the making," which is the title Prudence Roberts chose for her pamphlet accompanying the exhibit of the remaining plaster casts at the Portland Art Museum in 1987-1988. Emphasizing conservative social and cultural motivations, art historian Alan Wallach identifies the casts and the associated type of object study popular in the final quarter of the nineteenth century as "monuments to traditional learning and traditional concepts of civilization." 22 Even though enthusiasm for casts of antique sculptures would be relatively short lived, Wallach considers the period, which he calls "cast culture," critical to the institutional definition of art and cultural hierarchies. ${ }^{23}$

Considered from an art educational point of view, the use of reproductions and of copies of antique sculptures in the study of art was standard practice in academies and schools alike. Carl Goldstein's Teaching Art (1996), a 
detailed exploration of art academies from the Renaissance to the early twentieth century, reports that the study and copying of such objects were commonplace in European art academies. ${ }^{24}$ In fact, Goldstein observes the increased availability and quality of reproductions, including plaster casts, over the centuries. He also points out the many subtle shifts in mimetic theory, which promoted copies of the works of the masters and antique sculptures. Goldstein notes that professional art education by the 1920 s, rather than wholesale abandoning of copying, used casts "not to be imitated but rather creatively interpreted." 25

Educational historian Mary Ann Stankiewicz argues that study from sculptural and printed reproductions was a powerful means of extending art education and appreciation to schools and the general public in late nineteenthcentury America. The popularity of schoolroom decoration and picture study was made possible by industrial production and the decreased cost of artwork reproductions. Stankiewicz focuses on the popularity among arts educators of the so-called chromos which were multi-stone, colored lithographs most successfully marketed by Boston lithographer Louis Prang. She points out that the chromo reproductions gave arts educators access to masterworks, which they would otherwise not have available for instruction. At the PAA, the plaster casts and prints would be considered a key educational resource for visiting schoolchildren for decades to come. ${ }^{26}$

Local artist groups also used the cast collection for drawing sessions. Among these voluntary art organizations were the Portland Art Club, the Oregon 
Art Association, and the Portland Sketch Club. Close relationships between and overlapping membership in these groups were common. Corbett served as president of the Portland Art Club and secured a room for its use in the First National Bank Building. The Club merged with the Portland Sketch Club in 1898. Active members of the Sketch Club included Crocker, Clara Jane Stephens, and Harry Wentz, all of whom would later play instrumental roles in the PAA development of a museum and an arts instruction program. Drawing from and among the casts quickly became a routine activity for artists associated with various community groups. Crocker recalled very positively her own visits to and sketching time in the collection. " The reliefs around the walls and the figures standing in clear light and ample space showed so much enduring greatness, so much simplicity and largeness, that to a surprising degree, in spite of changed attitudes toward the classics and the healthy present day emphasis on originals, these sculptural copies continued to be enjoyed by visitors of all ages and classes." 27

A second group of reproductions secured by the Association consisted of a collection of carbon photographs of paintings and drawings from major collections in Europe. Funds from the Ladds, a prominent Portland banking family and long-term supporters of the Association, made this $\$ 15,000$ purchase possible in 1893. The Metropolitan Museum and the Boston Museum of Fine Art had declined earlier offers to purchase this collection and the sales information reached the PAA via its contacts at the Eastern institutions. ${ }^{28}$ It is interesting that 
the photographic reproductions have received no critical attention, in contrast to the suggestions of hegemonic class interests that have been made with regard to the purchase of plaster casts. I propose that this results from the casts' ability to grandly reference a sense of cultural heritage as well as their scale and threedimensionality. Furthermore, study from photographic reproduction continues to be so commonplace within the flow of information today, that the medium is, soto-speak, invisible and the Association purchase is noticed, if ever, only as a poor financial decision.

To display the collection and to store books and other reference materials, the founding trustees had secured the use of rooms at the Portland Library building. PAA founders had served as trustees to the Library Association and the Art Association as both organizations reflected similar values regarding individual improvement and civic pride. With the arrival of the plaster casts in 1895, the Association opened its museum in the unoccupied upper halls of the new Library building on Portland's Southwest $7^{\text {th }}$ and Stark streets. The Library, no longer a subscription club, was a logical host for the Association's objects and activities since it provided public access in a central location. The Portland Library Association had already held art exhibits on its premises prior to giving the PAA a regular presence. Indeed, the Library even owned artworks. Among them was an accomplished academy painting by Edward Lincoln Espey, Repose (Brittany Burial Ground), which had been purchased for $\$ 1,000$ after being exhibited in 1885 at a Paris Salon. Corbett had promoted the purchase of the 
painting, the largest sum paid by a civic organization to an Oregon artist. Like purchases of original artworks made much later by the PAA, this one was done by group subscription and preceded by fourteen years the Association's first purchase of an original work by a contemporary artist. ${ }^{29}$

The trustees' service and donations provided the link between Association and Library. Indeed, connections between arts and library organizations were common elsewhere in the country. The nationally prominent Picture Study movement connected the library movement with aesthetic education at the turn of the century. Libraries in major U.S. cities, such as Cleveland, Denver, and Milwaukee as well as the Pratt Institute in Brooklyn, featured images in their circulation collections. These pictures, primarily designed for children and youth, were often reproductions of Western canonical works but also included the work of recognized contemporary American illustrators. Libraries also circulated pictures through public schools, a service which the PAA would support significantly soon after launching its Art School. ${ }^{30}$ These Portland Library activities were well within a national trend. A century ago, public libraries owned art collections and regularly hosted exhibitions of loaned artworks. Hence, the nation's largest public libraries, Boston and New York, have considerable collections today, especially prints and photographs. But libraries did not simply present artworks, a service equal to that provided by the newly emerging art centers and museums. Rather, they assumed a particularly prominent role in the art education of the general public. Frank 
Weitenkampf, Chief of the Prints Division at the New York Public Library in the early twentieth century, suggested that libraries promote their own collections or that of local museums in order to extend the educational influence of these collections or museums. This was deemed especially valuable in connecting youth to art, a practice for which Weitenkampf counted on the close collaboration of public libraries, museums, and public schools. After all, the library and art education shared the goal " to bring the citizens to a realization of the applicability of art principles to the day's life." 31

The career of John Cotton Dana provides a particularly powerful example of the library and art education connection as well as of the popular call for democratic art and for general art education. Dana was elected president of the American Library Association in 1895 and became known as an advocate of a populist approach to art museum management. Accordingly, he championed library use and circulation rather than enshrinement of images and objects. In The Gloom of the Museum (1917) Dana criticized the Metropolitan Museum of Art and its peer institutions because they did not buy and did not elect even to display the work of contemporary artists and artisans in any field. Attacking their perceived elitism, Dana condemned these museums as "useless public institutions" that promoted "certain integuments of culture which, although they do not conceal aesthetic nakedness, inhibit the free exercise of both intellect and sensibility." 32 
Given the limited institutional networks at the time, it is perhaps not surprising that the PAA consulted with Dana, then librarian at The City Library Association, Springfield, Massachusetts, on organizational development. In correspondence with the Association's curator of collections, Henrietta Failing, in 1898, Dana described the many responsibilities of Springfield's Library Association:

This association has, in addition to a library of 100.000 volumes in its library building, an art museum containing an excellent collection of objects representing the industrial art of many nations, collected by Mr. George Walter Vincent Smith during the past 40 years. In the same building it has a small but very good collection of reproductions of Greek and Renaissance sculpture, chosen and installed by Mr. Henry W. Kent, curator of the Slater Memorial museum at Norwich Conn., in consultation with Mr. Edward Robinson at the Boston Museum of Fine Arts. ${ }^{33}$

At the time, the activities of the nascent Portland organizations paled in comparison with the Massachusetts organization. Until the start of its Art School and the creation of paid positions, Henrietta Failing, niece of founding PAA trustee Henry Failing, managed Association operations in her role as appointed curator. Failing occupied this volunteer position until the opening of the Art School and would teach art history, classics, and antiquity studies well into the 1930s. She managed the Association's recordkeeping, correspondence, and daily affairs. Most importantly, she secured loans from private collectors in Portland for exhibits at the Library and advised on development matters. She also expanded the PAA's collection of reproductions and books on European art, building a reference library for the study of the arts and antiquity. Failing contributed the following entry to a report by art writers and educators as part of a national symposium on art education and public schools in 1908: 
Co-operation with public schools, popular talks upon the exhibitions and collections, and efforts to awaken an intelligent public interest have been the purpose of the Museum from the first. A Teachers' Club meets alternate Saturday evenings during the winter. Four clubs are using the class room, and it can be secured for use by any group. ${ }^{34}$

Roberts has called the Association founding “an optimistic act, as neither a museum nor a collection existed." ${ }^{35}$ However, this type of endeavor represented a frequent alternative to the familiar donor-dominated collection or institution in late nineteenth-century America. Regionally, for example, similar beginnings can be observed in San Francisco and Seattle. The San Francisco Art Association incorporated in 1872 . A collection and museum would only become reality in 1895 after M. H. de Young, publisher of the San Francisco Chronicle, successfully lobbied the San Francisco commissioners to take over what had been the Fine Arts building at the California Midwinter International Exposition of 1894. The first exhibit consisted of the limited items that had been acquired at the Exposition. The museum later became home to de Young's eclectic personal collection, which included birds, eggs, handcuffs, knives and forks, and was named after de Young in 1921. Similarly, Seattle saw a series of art association foundings in the 1890s. Yet collection and museum creation had to wait until the arrival of a significant donor. A donation of late nineteenth and early twentieth century paintings by the Horace $\mathrm{C}$. Henry family began the collection of the Art Institute of Seattle in 1928, succeeded today by the Henry Art Gallery on the campus of the University of Washington. A donation in 1931 of Asian art by 
Richard Fuller and his mother, Margaret MacTavish Fuller, seeded the collection of what became the Seattle Art Museum in $1933 .^{36}$

The entry on American art museums in the Oxford Art Dictionary adopts a bemused tone when discussiing the Toledo Museum of Art, Ohio, which did not have a collection at the time of its founding. "On occasion, where civic pride demanded a municipal institution but the question of local private patronage was neglected, the ridiculous situation arose of a museum with empty galleries." ${ }^{\prime 37}$ The museum did, however, offer exhibits of artworks on loan. It also provided children's art classes for free and was successful in matching private challenge grants with public funds for museum expansion and operation in 1907 and 1916, without having a significant collection. ${ }^{38}$ This was strikingly similar to PAA efforts and represented an art advocacy movement supported by a surprising stream of popular, community-focused art enthusiasm, a tradition that has been obscured by the extraordinary success of the large donor museums in the second half of the twentieth century.

If canonical works of European modernism from the turn of the century represent the single measure, the Association's earliest efforts appear futile. Art historian Joshua C. Taylor, for example, has called the period from 1860 to 1900 a "crisis for art" in America due to the diversity of visual forms, old and new, and the changing attitudes toward the responsibilities of the artist and the purpose of art. ${ }^{39}$ In the realm of art education, however, Stankiewicz has shown that the prevailing attitude was one of close connection between aesthetic and moral 
education, implying a surprisingly broad role for visual art education in the general education of Americans. ${ }^{40}$ Aesthetic education was assumed to contribute positively to the character formation of individuals and to the civic constitution of communities. Art education ought not be limited to the training of artists but surfaced as an energetic stream for Progressive Era reform and civic institution building. This tradition informed the actions of the Association's founders. To occupy such a prominent and far-reaching role, art and art education had to provide more than training in the recognition and, for the talented, making of visual forms. Rather, art had to be conceived of as engendering moral and spiritual education. While such connotations had lost much of their traction with professional artists and aesthetic thinkers, they did remain strong within the field of art education. While ostensibly looking back to antiquity, art's presumed connection with morality and spirituality had varied nineteenth-century sources, with Romanticism and German Idealism providing a particularly forceful current. Art historian Robert Hughes has identified especially the work of Matthew Arnold, Walter Pater, Georg Wilhelm Friedrich Hegel, and John Ruskin as especially popular with American culture makers of the time. ${ }^{41}$ In America, the aesthetic and social ideas of British art critic and social theorist Ruskin supplied a particularly influential framework. Ruskin's ideas remained solidly institutionalized well into the early twentieth century at key institutions such as Harvard and Yale. Charles Eliot Norton, a Ruskin promoter, organized 
exhibitions of Ruskin's sketches in Boston and New York in the late nineteenth century. ${ }^{42}$

As one of the foremost cultural critics in mid-nineteenth century England, Ruskin's personal artistic predilections nevertheless had already begun diminishing his reputation and influence late in his lifetime. These included his privileging of Gothic art, his disdain for classical and Renaissance forms, and especially his infamous libel suit involving the American painter James Abbott McNeill Whistler, which revealed him as conservative and even incoherent. Such aesthetic conservatism was evident in what has come to be known as the Ten O'Clock affair, which originated in Ruskin's condemnation of Whistler's 1878 painting Nocturne in Black and Gold: The Falling Rocket. Ruskin charged Whistler with hollow aestheticism and with having "ask[ed] two hundred guineas for throwing a pot of paint in the public's face." ${ }^{43}$

Roger B. Stein has suggested in John Ruskin and Aesthetic Thought in America, 1840-1900 (1967) that at the dawn of the new century, American artists and art critics paid scant attention to Ruskin's doctrines of truth to nature, the morality of art, and the medieval ideal. Nevertheless, Stein purports that Ruskin remained "the most powerful spokesman of the moral and aesthetic side of Anglo-American social reform." ${ }^{44}$ Ruskin's initially enthusiastic American reception generally emphasized the democratic and popular thrust of his ideas. ${ }^{45}$ Rhetorically, Ruskin's preference for the craftsman over the connoisseur, for the people over elites, and for natural authenticity over mannered imitation, certainly 
meshed well with native traditions and ambitions. Although Ruskin's biting social critiques of Victorian materialism and of industrial labor conditions never received much attention in America, "a sort of generalized Ruskinism" - as William H. Wilson has described it - informed and infused the ideas and ideals of aesthetic improvement in the City Beautiful Movement in this country. ${ }^{46}$

Stein points out that Ruskin was particularly well received by both Progressive Era reformers and art educators. "Many Americans," Stein writes, "looked to Ruskin as the most powerful spokesman of the moral and aesthetic side of Anglo-American social reform and as 'an inspiration. ${ }^{, 47}$ Even philosopher and educator John Dewey's major work on aesthetics, Art as Experience (1934), based on his delivery of the first cycle of William James Lectures at Harvard University in 1930-31, echoed key elements of Ruskinian thought on the relationship between human activity, art, and society. In particular, Dewey posited a crucial link between individual aesthetic experience and collective life. ${ }^{48}$

The strong belief in the power of art and aesthetic education would not be limited to the Association's foundational era. The imperative of civic development and community engagement remained strong at the PAA throughout the period described in this thesis. "This is constructive work and makes for the best quality of citizenship," reported an Association publication in 1916. ${ }^{49}$ Art and aesthetic education held out the promise of engaging, not indoctrinating, individuals and improving the community, a significant legacy of 
the PAA's creation during a period of civic ferment and Progressive reform at the turn of the twentieth century. 


\section{Chapter 3: The Discriminating Eye: Elevating Taste in Art and in Craft}

Charles E.S. Wood and Julia Christensen Hoffman stand out among the Portland Art Association's early trustees and supporters. They not only contributed financially to the organization but brought Eastern artists and their work to Portland through their personal connections and friendships. Among the early stewards of the organization, only Wood and Hoffman pursued an active artistic practice. Wood was an accomplished painter and poet, Hoffman a photographer, painter, metalsmith, and weaver. Because of Wood's personal invitations, recognized contemporary artists came to the Association before the Art School. Though Hoffman is typically recognized only for her patronage of Arts and Crafts activities including the founding of the Arts and Crafts School in 1934, it was in large part due to her enthusiasm and financial gifts that the Association initiated a formal instructional program and founded the Art School in $1909 .^{1}$

Wood stood out among the PAA's founding trustees because of his own accomplished painting practice, his extraordinary connections to some of the best-known American painters at the turn of the century, and his efforts at cultivating fine art connoisseurship at the PAA and among Portland's first families. Wood first came to the Pacific Northwest during his military service. He served as an aide to General O.O. Howard in the 1870s, thereby becoming a witness to and recorder of the surrender speech by Chief Joseph, the leader of the Nez Perce. While studying law at Columbia University from 1881 through 1883 , 
Wood renewed his connections with prominent East Coast painters and sculptors. Important among these artists were J. Alden Weir, Albert Pinkham Ryder, Childe Hassam, and Daniel Cottier. Wood then returned to Portland and embarked on a successful career as a lawyer, as part of which he defended labor activists and birth control activist Margaret Sanger in Portland court proceedings. ${ }^{2}$ Wood was also a prolific writer and poet. In 1888 , Wood proved instrumental in securing Olin Warner to design the Skidmore Fountain, which remains one of Portland's popular public spaces to this day. As a founding trustee, he was the lone dissenter to the Association's purchase of the plaster casts, objecting "it was better to have one Rembrandt than it was to have a lot of copies." ${ }^{3}$ Wood promoted the work of his painter friends and popularized their contemporary American painting through the Association. Reflecting on the perception of the fine arts in Portland, he stated despairingly in 1898: “(O)f course chromos and cheap literalisms appeal to most of the Western folk." ${ }^{, 4}$ Nevertheless, Wood never tired of promoting work by American Impressionist painters. As a result, PAA trustee Ayer as well as members of the Ladd family purchased several paintings by Ryder and Weir. The trustees not only exhibited such works, but eventually bequeathed a good number of them to the Association. Art historian Prudence Roberts therefore credits Wood with having shaped the collection of the Portland Art Museum. ${ }^{5}$

Besides Wood, other trustees continued to contribute to the development of the Association, particularly in preparation for and in the context of the Lewis 
and Clark Centennial Exposition in 1905. As in other provincial American cities, urban leaders occupied key positions on the Exposition board and used the fair for economic and civic development. Association trustees secured a place for the arts and arts advocacy during the Exposition through the Fine Arts Pavilion. The first large-scale show of modern art in Portland at the time, the exhibit brought numerous American and European masterworks to Portland. Initially, this exhibit was conceived of as a reinstallation of the art that had been on display at the 1904 Louisiana Purchase Exposition in St. Louis, minus the artworks that had already been sold. ${ }^{6}$ It is not entirely clear what brought about the shift toward creating an original and ambitious art exhibit for the Portland Exposition. However, it is reasonable to assume that Association members supported the larger effort. After all, Corbett served as the Exposition chair until his death prior to the actual start of the fair. Ladd, the founding trustee who had given an extensive collection of photographs of European art to the Association, also served on the Exposition board. Failing, the Association curator, coordinated and advised on the selection and installation of artworks.

In Marble Palaces, Temples of Art (1998), Ingrid Steffensen-Bruce describes how late-nineteenth century expositions commonly launched a local art museum. In fact, Steffensen-Bruce observes that art museums were regularly founded in tandem with larger fairs and expositions in American cities between 1876, the Philadelphia Centennial, and 1915, San Francisco's Panama-Pacific Exposition. She suggests that these art museums functioned as "fair spectacle" 
and were mostly built in the classical idiom. ${ }^{7}$ For example, the Tennessee Centennial and International Exposition of 1897 gave Nashville a replica of the Parthenon. The building, which still serves as an art museum, is a full-scale recreation of its original, as is the forty-two foot statue of Athena, also located in Nashville's Centennial Park. However, Steffensen-Bruce also suggests that the Louisiana Purchase Exposition of 1904 in St. Louis represented "the culmination of nineteenth-century art-museum-and-exposition collaborations." ${ }^{8}$ St. Louis, in fact, already had a museum at a downtown location, which relocated to a new Beaux-Arts style building designed by architect Cass Gilbert as part of the 1904 Exposition. To this day the St. Louis art museum bears the inscription Dedicated to Art and Free to All.

A centennial or other large-scale exposition in the nineteenth and early twentieth centuries afforded U.S. cities the opportunity to raise funds, develop land and infrastructure, and erect buildings dedicated to commerce and civic activity. With regard to the visual arts, an exposition introduced the public to sizable art exhibits, which generally included contemporary work, primarily of European origin but also by American artists. The best-known fair was the World's Columbian Exposition of 1893, referred to as "White City" for its white plastered facades of Greek revival architecture. It remains the most controversial of such events, in part because of its scale, but especially because it embodied so many of America's social and cultural contradictions: Progress and restoration, cultivation and popular entertainment, populism and elitism, democracy and class 
antagonism, national identity and racism. This interpretation has been advanced by a number of historians. Especially compelling is Alan Trachtenberg's Incorporation of America (1982). Trachtenberg presents the fair's development as a metaphor for America's transition from its nineteenth-century mosaic of regional authority and differentiation to a nationally homogenized and stratified system. In his telling, Chicago's White City, in its planning, facilities, coordination, and segmentation of people, enacted and symbolized the new national political order. ${ }^{9}$

With regard to cultural production and consumption, Trachtenberg suggests that "[e]lite culture installed itself as official doctrine of the Court, claiming dominion over the 'low' confined to the outskirts of the Midway."10 James Parton Haney, a turn-of-the-century art educator and advocate, observed in similar fashion:

In its aesthetic influence upon the people of the country, the exhibition at Chicago was, if possible, more far reaching than that of Philadelphia. Its main buildings formed an imposing architectural unit, and its galleries, filled with pictures, statuary, and myriad products of handicraft, gave the vast throngs which gathered within its gates new standards of beauty and new canons of taste. ${ }^{11}$

John Charles Olmsted came to Portland in May 1903 to design a plan for the Exposition grounds and a city park system. Olmsted proposed to encircle Portland with a ring of parks, but failed to win approval for his vision. Instead, the board of the Lewis and Clark Centennial Exhibition chose to develop the marshy lands along the Willamette River north of downtown. ${ }^{12}$ 
Whatever the limits of fair planning, the Portland Art Association's exhibition and collection efforts made a significant step forward during the Exposition. Prior to the fair, the PAA had secured a downtown lot, and a substantial initial endowment when Corbett bequeathed a property at Southwest Fifth and Taylor Streets and made a challenge grant of $\$ 50,000$. Within months of Corbett's passing, Ladd died, and his widow, Caroline Ladd, gave $\$ 30,000$ to the Association for the purpose of erecting a museum building. ${ }^{13}$ Construction began in July 1904 in time for the Lewis and Clark Exposition. The building, which would serve the PAA as museum, lecture hall, and art school through 1932, made it possible to present an expanded art exhibit as part of the Exposition.

While the Exposition provided a sizable space for its Fine Arts Department exhibition, the Association located its museum building among Portland's other civic and commercial institutions. The downtown Portland location was in part a result of Corbett's land donation, a combination of topography and local land speculation, and the failure to adopt the Olmsted plan in preparation for the Exhibition. Consequently, the museum found a place right in the heart of the city, not in an area remote from the center, as was the case for the Boston Museum of Fine Arts, the Metropolitan Museum of Art in New York, and the museum in St. Louis. Choosing a downtown rather than a pastoral setting reflected a belief in the important civic and educational capacity of the arts and joined Association activities with other Portland civic improvement efforts. 
As Steffensen-Bruce has suggested, democratic claims and popular appeal constituted a frequent feature of museum-building and advocacy during this period:

[T]he art museum could uplift the urban denizen both morally and spiritually through the educational influence of the art it contained, as well as through the physical appearance of a well designed building. As art institution and as architecture, the art museum was both a practical device and a hopeful symbol to the turn-of-the-century interest in urban improvement. $^{14}$

Furthermore, Steffensen-Bruce points out that a classical architectural style was the common signifier of museum civic aspirations and operations. The PAA, however, chose an architectural style for its building which eschewed both classical revival and ornamental pomp. Instead, Portland's new museum exhibited a simple, utilitarian look that reflected a belief in the educational mission of art. The Association's decision preceded by a decade the creation of a similar, permanent building for the Newark Museum in New Jersey, which then was under the leadership of John Dana Cotton, the important populist champion of art museums and libraries. ${ }^{15}$

The new PAA building was used for a portion of the Exposition's arts exhibit. The so-called "Section B of the Fine Arts Department Exhibition" presented four hundred artworks - works that became the new Museum's inaugural exhibit. All works were by Oregon artists. Among these, Clara Jane Stephens, Harry Wentz, and C.E.S. Wood had, or would have, leadership roles during the Association early decades. Stephens and Wentz both became distinguished and long-serving instructors at the PAA's art school and played 
important parts in the PAA's educational mission. Other exhibited artists from Oregon included Josephine T. Hayne and Alice Aubrey Weister, who had been members of the Portland Sketch Club and the Oregon Art Association, as well as Helen Savier DuMond, the wife of painter and exhibit curator Frank Vincent DuMond. Savier's inclusion was not simply a matter of spousal privilege. She had studied at the New York Art Students League and had also received private painting instruction in Paris, where she had exhibited at the Salons of 1897 and 1898. Another Oregon painter whose work was included in the exhibit was Eliza Rosanna Lamb Barchus. It was she who won the gold medal at the Portland Exposition. Given the elevation of European master works at the Exposition, there was a certain irony in Barchus winning the award since she painted primarily Western scenes sold at modest price but in great volume to a national audience. $^{16}$

Frank Vincent DuMond's role in the Exposition was of particular importance for a number of reasons - chief among them that he single-handedly shaped the content of the main PAA exhibit. DuMond was a nationally recognized painter and an even more respected arts educator. He had a distinguished teaching career at the New York Art Students League, where he served as a leading studio arts instructor for many of the years between 1892 and his death in 1951. The New York Art Students League and DuMond's classroom were prime destinations for American studio artists, including Portland artists such as Crocker and Wentz. ${ }^{17}$ 
The Exposition's planning committee had initially been determined to have an arts pavilion on the Exposition grounds, as was standard practice at other fairs, and, as described above, to display art from the earlier St. Louis Exposition. However, the committee abandoned this formula and gave DuMond complete curatorial freedom. Instead of grouping artworks by country of origin, DuMond sought to realize significant educational possibilities through a comprehensive exhibit and established curatorial criteria informed by periods, schools, movements, transitions, and influences. ${ }^{18}$

DuMond's exhibit covered two hundred years of Western art, with masterwork paintings of the French Barbizon and Impressionist movement particularly well represented, including work by John Constable, Gustave Courbet, Edouard Manet, Claude Monet, Camille Pissarro, and Auguste Renoir. Noted American painters were also part of the exhibit, including contemporary artists such as Mary Cassatt, William M. Chase, Arthur B. Davies, Morris Prendergast, and Alfred Stieglitz. ${ }^{19}$ To realize his curatorial ambitions, DuMond successfully solicited the support of several noted galleries. Among them were Frederic Cheever Torrey of San Francisco and William Macbeth of New York, both recognized champions of American modern art. Other lenders included Durand-Ruel Gallery, Cottier \& Company, Alfred Stieglitz, William Merritt Chase, and the Spreckels family, donors of the art collection and facility for the California Palace of the Legion of Honor in San Francisco. ${ }^{20}$ 
DuMond influenced the PAA and the Portland art community in ways that went above and beyond the Exposition itself. He had taught regularly in Portland from 1895 through 1900, a period during which he and his wife frequently spent time in the area. He also led classes at the personal studio of Julia Hoffman, the first lifetime member of the PAA, a generous Association donor, and a leader in founding the Arts and Crafts Society and School in Portland. ${ }^{21}$ DuMond, moreover, had taught studio classes at the Association's rooms in the Library. Crocker described his teaching as a welcome break from self-study for the artists gathering at the PAA for weekly exercises. ${ }^{22}$ This arrangement led to a short summer program with evening and weekend sessions. The classes were held at the Association; participating community artists covered DuMond's instructional fees. ${ }^{23}$ Following the New York model, Crocker, Wentz, and others reorganized the Portland Sketch Club as the Oregon Art Students League (OASL) in 1906.

Despite DuMond's opposition, the Exposition also marked the arrival of the Arts and Crafts movement in Portland. Artisans and their craft were widely represented among the fair's various exhibits, even though DuMond banished craft objects from his fine art exhibit. ${ }^{24}$ Most importantly, PAA trustee Hoffman began her vigorous campaign for the Arts and Crafts. Shortly after the Exposition, the Association's new museum hosted Portland's first Arts and Crafts exhibition. The prominence given to aesthetic education and to refining tastes in art and in craft produced decades of collaboration and coordination 
between what are commonly perceived as two different, even oppositional, arenas of artistic activity. In Portland's early twentieth century, however, advocates and practitioners were united in their desire and actions for art education for a broad public, with the Association providing the organizational platform. Collaborations across the fine art and craft divide included the involvement especially of Hoffman, but also of Wood; both were instrumental in the founding of Portland's Arts and Craft Society. Such collaboration continued in joint educational programs as well as the work of Crocker and Wentz. Lawrence Kreisman and Glenn Mason have described the extended engagement of the Association and several of its leading trustees with the Arts and Crafts movement and activities in their comprehensive history, The Arts and Crafts Movement in the Pacific Northwest (2007). They document multiple instances of individual and organizational boundary crossing between the fine art and the crafts. In regard to the coexistence and even fusion of the two, Kreisman and Mason describe an "enlightened attitude" at the PAA during the early decades of the twentieth century.

Association member Hoffman, following the death of her husband in 1895 , had relocated her family to Boston for several years. There, Hoffman continued her painting studies at the Boston Art Students' Association and participated in other artistic and cultural organizations. Most importantly, she joined the newly organized Boston Society of Arts and Crafts. Hoffman again made Portland her permanent home in 1906, although continued travel allowed 
her to maintain her connections, especially with the Boston Society of Arts and Crafts. Hoffman was instrumental in starting the Portland Arts and Crafts Society, which was founded in October 1907. In addition to Hoffman, PAA trustees Wood, Lamb, and Charles Carey were charter members of and actively supported Portland's Arts and Crafts Society. A nationally prominent figure in advocating for a range of artistic media and practices was Harvard art historian and first president the Boston Society of Arts and Crafts, Charles Eliot Norton, with whom Association trustees had consulted about the selection of its plaster casts. In short, many Portland art champions vigorously promoted both "camps" of artistic endeavor for the sake of the benefits that aesthetic practices on both sides of the divide seemed to hold for individuals and the community alike.

A significant opportunity for expressing and supporting Arts and Crafts ideas arose when, at Hoffman's suggestion, the PAA exhibited an ambitious selection of craft objects in the spring of 1907. Hoffman had visited a Boston Society of Arts and Crafts exhibition earlier that year and had, in consultation with PAA curator Failing, selected objects from that show for a loan to the Association. The PAA exhibit included jewelry, metal, leather, fiber works, book arts, and ceramics (woodworking constituted a curious absence, perhaps because of the space constraints in the Association's gallery). Antique objects from local collectors supplemented the exhibit. Kreisman and Mason contend that the exhibit represented a veritable "Who's Who" of the American Arts and Crafts movement. They further suggest that the objects loaned by local collectors 
reflected familiarity with and ownership of items from the most recognized artisan producers of the day, such as ceramics from Rookwood, Volkmar, and Newcomb. The Spectator, Portland's weekly newspaper, hailed it as "the most interesting and instructive exhibit ever given at the [PAA] museum." ${ }^{, 25}$

The Arts and Crafts movement offered an attractive mix of ideas. It asserted the dignity of labor, promising both individual fulfillment and social uplift without a radical political program. The Arts and Crafts principle of remaining "true to materials" when crafting objects suggested that making beautiful things was a sort of natural state or process. And, as art historian Wendy Kaplan has pointed out, the "Arts and Crafts ideal was not so much a style as an approach, an attitude toward the making of objects. ${ }^{26}$ Thus, the movement functioned as an effective unifying force for those who viewed the arts as an instrument of personal and social development. Locating such a purpose in art also meant that its advocates championed aesthetic education for everyone. As William Morris, the Arts and Crafts movement's best-known British theorist and artisan entrepreneur, rhetorically put it: "What business have we with art at all unless all can share it?"27

The Arts and Crafts movement did not simply elevate handicraft over industrial production. Its representatives issued a political and moral challenge to the deterioration and alienation of the laborer in the new industrial economy of mass production. Those who promoted Arts and Crafts ideals objected to the impoverished material condition of labor and the inequality of social conditions 
in industrial society (although they rarely went so far as to espouse the socialist ideas held by Morris). Work's objective should not be simply the satisfaction of material need; rather, they felt, it should have a spiritual dimension as well. Hence, the literature of the Arts and Crafts movement provides myriad variations on the phrase "the art that is life." ${ }^{28}$ While Arts and Crafts advocates in the United States also objected to the dehumanizing effects of specialization and the routinization of labor in industrial production, they rarely did so with an explicit political commitment. Rather, Arts and Crafts ideas and slogans played most effectively on American ideals of individualism and producerism. Here, individual improvement would affect social conditions and strengthen civic life and institutions, not the reverse.

While in many respects the Arts and Crafts movement issued an anachronistic, even anti-modern, response to industrialism and societal conditions, its popular appeal at the time was significant. With roots in nineteenth-century England and continental Europe, the movement found a particularly receptive audience in the United States at the beginning of the twentieth century. Eileen Boris reports that between 1896 and 1915 an active network of thousands of organized groups of craft makers, entrepreneurs, and appreciators spanned the entire United States, culminating in the formation of the National League of Handicraft in $1908 .{ }^{29}$ She points out that professional artists, architects, and art workers found a broad audience of amateurs and patrons, who joined the various societies in great numbers. The associations formed in Boston 
and Chicago represented the nationally most visible and influential of the arts and crafts societies. The Arts and Crafts movement led to the founding of utopian communities such as Julius Wayled's "Ruskin" in Tennessee and influenced developments in settlement houses including Ellen Gates Star's and Jane Addams' Hull House in Chicago. The movement also gave rise to furniture workshops such as Elbert Hubbard's and Gustav Stickley's and informed contemporary architecture, as in the work of Frank Lloyd Wright and Charles Sumner Greene and Henry Mather Greene. The movement's network for selling craft objects through societies and expositions ultimately failed to provide sufficient and stable income for the majority of individual producers and the notion of the autonomous craftsman remained a nostalgic ideal untenable in the industrial economy. Nevertheless, as Wendy Kaplan has observed, the Arts and Crafts movement did profoundly change attitudes toward the fabrication and use of objects, thereby altering ideas about product design and the organization and meaning of home and work. ${ }^{30}$

Robert Edwards has pointed out the irony inherent in the success and broad appeal of the Arts and Crafts movement in America. Edwards has shown that the presumed anti-industrialism motivating and informing the Arts and Crafts movement for the most part ignored the fact that industrialism itself had created the conditions favorable to the development of leisure time as well as the privileging of handicraft. In fact, Edwards suggests that "the transformation of handicraft from an essential skill for earning a living to a nonessential 
enrichment of leisure time was arguably the most pervasive and long-lasting Arts and Crafts legacy." ${ }^{31}$ Edwards also points out that the handmade object could not compete with the consumer goods and prices of industrial production and distribution.

Portland arts educators did not share such criticism of Arts and Crafts ideals. In fact, the opening of the Association's museum and the founding of Portland's Arts and Crafts Society paved the way for the city's first art academy. Hoffman was especially eager to see an educational program started and insisted in a letter to Corbett and Failing that "Portland should certainly be an art-center where student $[\mathrm{s}]$ could come from surrounding sections of the country and have advantage of study that they now seek in San Francisco and the East."32 Hoffman's advocacy and support of Association programs would continue through the decades as she collaborated closely with Crocker. ${ }^{33}$

The PAA continued to present the fine arts to Portland audiences. Regular exhibits on loan came from the collection of William Mead Ladd and Mary Andrews Ladd. Their most prized possession was an extensive print collection that traced five centuries of graphic arts in Europe and America. It eventually contained nearly six thousand prints including work by great masters such as Rembrandt van Rijn and Albrecht Dürer as well as by contemporary artists Wassily Kandinsky and Käthe Kollwitz. Art historian Lisa Dickinson Michaux suggests that in early twentieth-century America the Ladds' print collection was rivaled only by that of New York art dealer Samuel P. Avery. ${ }^{34}$ Most importantly, 
though, C.E.S. Wood connected the organization and the Portland public with recognized, contemporary art. In his most ambitious endeavor, also the PAA's largest exhibit following the Exposition, Wood curated a show of over two hundred paintings at the Association's museum, in which he included a significant number of works by the artist friends he had championed through the years, especially Ryder, Weir, and Hassam. More than ten thousand visitors, fewer than had come to the Exposition fairgrounds, but many times the number of people who visited the PAA each year, viewed that exhibit from June through October of $1909 .^{35}$

Wood's friendship with Hassam proved particularly successful. In 1908, on Hassam's second visit to Oregon, the two undertook a painting and hunting trip to Eastern Oregon. Upon their return to Portland and before shipping the paintings back East, Wood arranged for an exhibit at the Association of thirty of Hassam's Oregon paintings. Most importantly, Wood persuaded six other PAA members to purchase one of the canvases by joint subscription. Thus in 1909, Hassam's Afternoon Sky, Harney Desert (1908), a bright, Impressionist Oregon high desert landscape, became the Association's first original work of art. Wood's advocacy for contemporary American art clearly had an impact on the Association and community members connected to it. Thomas Lamb Eliot, the indefatigable PAA trustee and fundraiser and board member of many other charitable organizations, acknowledged that he was "learning to understand, and to a certain degree, reverence work like Mr. Hassam's, which, I confess, at first 
was hard for me to even understand much less find attractive." ${ }^{36}$ And just as Wood's exhibit closed, the Association opened the doors of its new school, thereby embarking on its most ambitious project in terms of education of the public and refinement and elevation of taste in the community. 


\section{Chapter 4: The Portland Art Association and the Art School}

In founding an Art School in 1909, the Portland Art Association (PAA)

embarked upon an endeavor that strongly reaffirmed the organization's

commitment to art education. Art School programs supported the cultivation of taste and art appreciation in the public at large and provided basic art instruction for the artist, architect, and craft worker. The commitment to an Art School also crystallized a double tension, which determined the identity as well as the opportunities and challenges of the Association for decades to come. Finding a balance between art instruction and collection building presented one challenge to Association operations and resources. The PAA encountered another difficulty in reconciling its ambition for professional preparation in the studio arts and its aspiration for an art appreciation service to the general public.

Beginning in October 1909, the organization moved beyond the incidental events and activities promoted and organized directly by trustee initiative, money, and connections. The new Art School offered a program in studio art study; a year-round lecture cycle on diverse topics in art history, archaeology, art education, fine art, and craft; as well as an on-going professional exhibition program. The School aspired to be an arts academy for the easel painter or sculptor with professional aspirations, but did not boast nationally renowned teachers or graduates in its first decades. Yet the Art School was not a meeting ground for dilettantes. School programs and instruction brought a wide range of art forms to Portland, including contemporary work, that increasingly 
reflected the many new ideas emerging in art and especially in art and museum education at the beginning of the twentieth century.

The Association's annual report of 1910, issued at the close of the School's inaugural year, boasted the success of the new educational endeavor:

The most important undertaking of the Association during the year was the opening of the Art School. The importance of this step, it is believed, will become greater, as year by year, the school develops, and in developing, increases both the demand for and the supply of those things which make for artistic culture. ${ }^{1}$

The Art School expanded the Association's service to the Portland public at large through its new programs. This meant more work than in the preceding decade with Portland schools, teachers, and students; more museum visits by school classes and students; and new endeavors that brought the arts into Portland Public School classrooms. Significantly, the opening of the Art School represented a fundamental transition in the organization's operations and decision making, which shifted from voluntary trustee service to professional employees. The PAA trustees previously had exercised organizational authority and procured services. Trusteeship now focused on fundraising, donation of artworks, and community. From this point, the operations and the development of the Association were carried out by a small but steadily growing group of professional employees. These new professionals normally had completed an education in studio arts, which in its eclecticism was typical of the time. They also shared a more-or-less formal preparation for teaching art. While few in 
number, the professionals nevertheless connected Association operations with the various professional networks and national organizations for art and museum education that had emerged at the beginning of the twentieth century. ${ }^{2}$

The creation of a formal education program for extending and deepening the aesthetic experience and understanding of Portlanders had been an ambition of the trustees since the Association's founding. In their quest to establish an art school, PAA trustees considered the benefits of an art academy for training a specialist audience and their desire to extend art appreciation and education to Portland's general public. A noted art academy was considered a sign of progress that would boost the city's reputation over regional rivals, both of which were of interest to trustees in civic leadership positions and a running theme in the press of a regional center. Yet practical matters needed consideration, such as the relative small size of Portland, its distance from the nation's art centers in the East, and the absence of a commercial art scene to support working artists and supply the qualified studio masters who could serve as academy teachers.

Henrietta Henderson Failing, the Association's volunteer curator prior to the Art School's founding, expressed her desire for and concerns about establishing a high-quality art academy in Portland. While on an extended tour to Europe's major art museums and academies in 1909, Failing reported in a letter to Thomas Lamb Eliot, then serving as the Association's Vice-President:

I hope even more as I go north to find in the practical workings of the big institutions here, hints that will be of service in our own work at home. I wish a summer school under some really good master could be managed. At least as far 
as I have considered it, that seems better than an all year session under mediocre training. ${ }^{3}$

Summer master classes had worked well for Portland and the Association in the past. Frank Vincent DuMond had led a summer program in Portland during 1904, and Julia Hoffman had organized a popular summer workshop in 1907 with renowned Cleveland, Ohio, silversmith Mildred Watkins. Furthermore, serious Portland art students often spent their summers, or longer, at the art academies and art colonies in the Eastern United States and in Europe. In fact, the education of the nineteenth-century American studio artist typically consisted of an eclectic mix of local, national, and European experiences as standardization, regulation, and certification of art education would emerge in America only after the turn of the century. The European academy model, already in decline due to challenges by modernist aesthetics and economic trends in the arts and artistic professions, did not fit the diverse educational needs and the different traditions of patronage in the United States. ${ }^{4}$

In launching its Art School, the PAA sought to balance a desire for a serious academic studio study with a commitment to art appreciation and education for the general public. Unsurprisingly, therefore, the Association hired an art educator, not a master artist, when Hoffman, longtime trustee and Portland Arts and Crafts Society founder, offered to fund a teaching position for an entire year. ${ }^{5}$ The Association turned to Columbia University's Teachers College of New York and selected the young art educator Kate Cameron Simmons, a 
graduate of the Pratt Institute, as its first instructor for the inaugural 1909-1910 school year. The Teachers College was the nation's leading institution for teacher training during much of the twentieth century. At the time, philosopher John Dewey and art educator Arthur Wesley Dow both held appointments at the institution. Their innovative ideas about art education and its role in general education and human development influenced a generation of teachers and Simmons very likely studied with one or both of them at Columbia University. Simmons's general art education background matched the diverse educational interests and needs of the Association perfectly. Her hiring fulfilled the organization's mandate for general art education and aligned closely with the interests and activities of Portland's Arts and Crafts community at the time. This alignment was not simply a brief, transitional arrangement but would remain a constitutive element of PAA art education. Indeed, Hoffman continued to make financial and material gifts to the organization and served on the Association's Art School committee until her death in 1934, the year when the Portland Arts and Crafts Society opened a permanent school. Until that time, the Art School served as Portland's educational center regardless of artistic medium. ${ }^{6}$ Importantly, it was not simply the popularity of the Portland Arts and Crafts Society that established a central role for handwork and design in instructional and curatorial programs at the PAA during the 1910s and 1920s. Rather, general art education was assumed important even in industrial training. As art education historian Arthur Efland reports, industrial and trade training at 
the time was widely expected not only to provide vocational preparation but also to nurture an appreciation of and skills in uniting utility and beauty. In fact, Association fundraising letters to Portland business leaders in support of the Art School referred to art education's benefits for community refinement and for local industry. Similar to Efland's observation, Foster Wygant, historian of school art education, suggests that the belief in unity of all artistic endeavors was particularly popular among art educators in the Progressive Era who challenged the distinction and the implied hierarchy between "fine" and "manual.",

The PAA offered the position of curator, principal, and secretary to Anna Belle Crocker. This was now a paid position and made Crocker more than the Association's curator of exhibitions and collections. In addition to her responsibilities for PAA exhibitions, Crocker served as the organization's executive director and secretary. She also lectured regularly, taught classes and, as she put it, took care of "executive details and other maid-of-all work duties.", Prior to becoming the Association's curator, Crocker had worked as a clerk at the Portland bank of William Mead Ladd, a founding member and trustee of the PAA. Crocker's memoir, It Goes Deeper than We Think (1946), explained that she learned of her appointment while on leave from her bank job in Portland to study at the New York Art Students League, her second stay there after a first visit in $1904 .{ }^{9}$ While in New York, she studied with DuMond at the Art Students League and with Robert Henri at the Chase School, which today is the wellknown Parsons New School for Design. ${ }^{10}$ Such studies in residence 
complemented her continued studio practice at home in Portland and her participation in local artist associations such as the Portland Sketch Club and the Oregon Art Association, renamed the Oregon Art Students League a few years after its founding. Crocker, apparently without prior knowledge of this opportunity and hence surprised by the offer, immediately confirmed her appointment by telegram. She also accepted the condition of visiting art institutions in the Eastern United States and Europe before returning to Portland in September 1909, just in time for the start of the Art School programs. ${ }^{11}$

In its inaugural year, the School offered five classes: General Drawing, Design, Color, Life, and Sketch. Additionally, shorter sections of the General Drawing and Design courses ran on an evening schedule in order to accommodate the schedules of working people. The cost for full-time attendance was $\$ 60$ in tuition and a $\$ 1$ laboratory fee. This represented a significant cost and difficult time commitment for working people. Consequently, the majority of students only chose to enroll in individual classes at reduced expense. Crocker also delivered a weekly lecture entitled "Understanding Painting and Sculpture," which was a blend of art history, theory, and criticism. Attendance at the lectures was expected of students enrolled in the Art School, but the presentations also served the general public. Association members, school teachers, high school students, Y.M.C.A and Y.W.C.A students were admitted without charge; others could attend for 25 cents. ${ }^{12}$ For the first time, a formal, year-round, and fee-based program of studio art study was available to Portland adults outside of private 
instruction arrangements or membership in arts-related volunteer associations.

With an enrollment of 98 adult students during its first year, the School exceeded expectations and captured the attention of Portlanders interested in the arts. The majority of students were women, and virtually all listed Portland or the surrounding area as their residence, although there were three students from Idaho, Iowa, and New Mexico respectively. ${ }^{13}$ Crocker described the students' artistic interests as diverse and differing widely between personal enrichment and vocational motivation:

A group of amateur workers in simple forms of crafts - book-binding, weaving, metal work, pottery - had asked for class work in design. There were young people to whom the big art schools at a distance were not immediately accessible, wishing for training in drawing, painting and composition; and older ones with the same desires, some of whom had worked together previously in museum corners. ${ }^{14}$

Vocational and professional interests figured prominently among architects, individuals with drafting or illustration positions, craftworkers, art teachers, and those with interests in future study at art schools in the East or in Europe. At the same time, the classes also served adults who did not pursue careers or intend to draw their livelihood from their artistic practices. While their motivation may be best described as leisure and enrichment, these students quite frequently had serious commitments to and experience in their practice. This was especially true of women working in ornamental and domestic arts and those who stood in loose affiliation with Portland's vibrant Arts and Crafts movement. Hence, Crocker summed up the Art School mission as providing students with 
"such training that their knowledge of the arts and their practice in them would enrich their lives afterward, no matter what their chosen vocation." 15

The Association's mission for popular art education also received a boost. Prior to the Art School's opening, the PAA had simply been a destination for a limited number of visitors. Contributing to a survey of educational activities at American art museums in 1908, Failing had described the Association's primary aspiration as awakening an informed interest in artistic culture and heritage among the Portland public. However, talks and exhibitions had been rather limited and only a few local, voluntary associations, including the Teachers' Club and the Portland Sketch Club, used the Museum on an occasional basis. ${ }^{16}$ With a curator and teachers in permanent employment and aided by volunteer docents, the Association offered greatly expanded museum hours and more frequent lectures and exhibitions. Furthermore, Association activities now represented art appreciation and education programs for the general public and provided an informational and interpretive context generally not made available during the PAA's first decade. The Art School also began offering children's classes, as did many other American art organizations and museums at the time. For example, the Toledo Museum of Art had even made its children's classes free of charge as far back as $1903 .{ }^{17}$ The Greek and Roman plaster cast collection became an ever more popular destination for children as school teachers brought classes more frequently to the Museum. Primarily, students came to see the antique cast collection, and occasionally, the museum's temporary exhibitions. 
Upon arrival, visitors received instructive talks about the meaning of the work aided by lantern slides of the artifacts and their presumed places of origin. Only after the identification and contextualization of the pieces did students encounter the "real" objects in the exhibition rooms. Crocker observed that this preparation made the visiting youth much more interested in their objects of study. This much-modernized presentation of objects and information reflected then current aesthetic education at leading art centers and museums in the East including the Metropolitan Museum of Art in New York and the Museum of Fine Arts in Boston. For example, Benjamin Ives Gilman, secretary of the Museum of Fine Arts had established a program of museum lectures and publications in 1906 to facilitate learning, over mere adulation, and to counter "museum fatigue," a term used by concerned museum and art educators at the time. Art historian Philip D. Spiess reports that Gilman first promoted the term "docent" to describe the new practice of guided museum visits in $1915 .^{18}$

Student responses to those visits regularly made it into the Association's publications and into the local press. For example, essays by students from Portland's Washington High School described how their class visit to the cast collection complemented literary studies of ancient Greece. One student noted a heightened interest "when you get right next to the thing itself;" impressed by the beauty of the cast, another desired to travel to the Louvre in Paris, to see the real statues some day. ${ }^{19}$ At the conclusion of the Art School's inaugural year in 1909, almost 20,000 individuals had visited the museum within a period of twelve 
months, a result the PAA sustained almost every year during the 1910s. Association reports noted with particular pride the thousands of school children served. In 1919, following steady annual increases, more than six thousand children visited the museum and several thousand more attended presentations by Association docents in their respective schools.$^{20}$ The casts proved popular beyond the classroom, exciting entire school communities and their families. Historian of American art education Arthur D. Efland traces the origins of the schoolroom decoration movement to Boston's Public School Art League, which formed in 1892 and served as a template for efforts in cities across the United States. ${ }^{21}$ Henry Turner Bailey, a leading art teacher and administrator in Massachusetts schools, who eventually served as the head of the Cleveland Art Institute until his retirement in 1930, was one of the Boston Art League's main activists and promoters. Bailey insisted that the schoolroom be "decorated and furnished in such a way that its equipment and appearance are calculated to promote the growth of skill and taste." ${ }^{22}$ Art historian Mary Ann Stankiewicz confirms that American school beautification efforts at the time were grounded in assumptions "that exposure to works of fine art could help students develop spiritual and practical virtues."23

Portland Public Schools enjoyed the presence of an energetic School Beautifying Committee, which advocated for the improvement of a variety of facilities to benefit the city's school children. The Committee also oversaw the promotion, fundraising, and selection of plaster casts and friezes of Greek, 
Roman, and Renaissance art at numerous schools. Members regularly met at the Association's museum and consulted with PAA staff. For example, Failing served as the PAA advisor to the Committee in the selection of plaster casts of Renaissance sculptures for the Kennedy School in Northeast Portland. Similarly, Failing served as an advisor for the choice of a large still-life painting for Lincoln High School in downtown Portland. ${ }^{24}$ When the Parthenon friezes in the former public library building were removed, the Association ensured the proper deinstallation and conservation of the plaster slabs and their distribution to Portland Public School buildings. ${ }^{25}$ The PAA could look with satisfaction at its role in advancing school beautification throughout the Portland community and in fulfilling a central goal of the City Beautiful movement.

The Association also expanded the collection of its photographic reproductions and their circulation among the general public and Portland schools. The use of photographic reproductions, especially of canonical works of Western art, was closely aligned with the motivations and goals of School Beautification activism. Advances in reproduction and printing technology, from choromolithographs to photomechanical processes, had progressively reduced production costs and thus expanded the availability and circulation of reproductions during the final decades of the nineteenth century. Across the United States, educators used reproductions to cultivate aesthetic and moral sensibilities among children and youth, a practice known as Picture Study. In Portland, the Association made Picture Study a primary responsibility of its new 
Art School. The PAA's “Bulletin No. 1," published in November 1909, illustrated this organizational commitment. Of the bulletin's eight pages, seven served as a manual for a so-called Pictures for Schools program in Portland schools. Only one page, the last of the brochure, was used to describe the studio courses for adults at the new Art School. Hence, the bulletin served both as a basic instructional reader to the proper pedagogy of Picture Study and as an advertisement of the Association's services for teachers and schools. In fact, the PAA noted contentedly that its bulletin enjoyed a wide circulation and even was requested by a reader as far away as New York. ${ }^{26}$

In Portland, the service proved widely popular and the Association put together sets of reproductions that PAA members and staff delivered to and presented in city schools with the cooperation of Portland Public Schools and the County Library. During the school year 1914-1915, the PAA reported that members of the School Beautifying Committee prepared 841 of the Association's reproductions and placed them in the circulating collection of the County Library. ${ }^{27}$ To satisfy the growing demand for this service, the organization created a permanent position for a school docent in consultation with the board of Portland Public Schools, which funded the position. Ione Dunlap, an Association member and volunteer, was hired for the position. With Crocker, Failing, and Simmons (or her successor instructors) already offering talks and guided tours at the museum, Dunlap added to the organization's capacity to serve the public and coordinate with public schools. Dunlap's service immediately increased the 
number of classes and students received and instructed in the Association's galleries. Dunlap now coordinated a school district-wide effort, arranged the traveling exhibits through the Library circulation system, and trained volunteer docents from the Association, the School Beautifying Committee, and the Association of Collegiate Alumni. In October 1915, the Library exhibited a circulating collection of pictures, allowing the general public and many teachers to acquaint themselves with this multi-organizational service. Dunlap arranged classroom visits with school teachers, for which she chose reproductions of artworks and prepared talks that corresponded to the particular subject studied by the class, be it an art, history, literature, or geography course. Dunlap also joined the new Advisory Art Committee of the Portland School Board, continuing the Association's earlier collaboration with the School Beautifying Committee in inspecting schools and advising on facility decoration. Stankiewicz purports that the use of reproductions of canonical art and artifacts and, for the youngest school ages, contemporary American illustrations of pastoral or domestic scenes, became standard curriculum aids in American schools from roughly 1885 to 1920. She refers to the period as a "Picture Age" in general education and schooling, a service that remained popular in Portland well into the 1930s and corresponded with the nation-wide popularity of Picture Study in school curriculum and instruction. ${ }^{28}$

The mandate for serving schools, teachers, and children was evident in other Association activities as well. The Museum hosted general meetings and 
activities for teachers. Crocker also held special receptions for school teachers and principals during which she would lecture on art pedagogy.$^{29}$ During the holiday season exhibits were put together to appeal to Portland's school and underage populations. For example, during the Christmas season of 1916, the Museum displayed an exhibit of reproductions and original works on loan which represented Christian scenes such as the Annunciation, Nativity, the Adoration of the Shepherds and Magi, the Flight into Egypt, and the Holy Family. The Association also continued its program of lectures and presentations to the community. Prior to the start of the Art School, Failing had provided a small number of gallery talks. These had covered almost exclusively historical topics, especially Egyptian, Greek, Roman, Early Christian, Byzantine, Gothic, Medieval, and Renaissance art. The discussion and appreciation of artistic, artisan, and archaeological artifacts as well as of architecture had been the focus of the Wednesday Morning Art Class, which the Association had sponsored every year since 1898. In the decade preceding the opening of the Art School, the class had covered the following topics in annual sequence: Greek and Renaissance Sculpture; Ancient Painting in Egypt, Asia and Europe; Leonardo da Vinci, Michael Angelo, Raphael; Correggio, the Venetians, American Painting; Dutch and Flemish Painting; German and Spanish Masters, Etching; French Painting; English Painting; Japanese Prints; Gothic Architecture; Egyptian, Assyrian and Early Greek Art. ${ }^{30}$ Such efforts were rooted in the idea and practice of a classical education and the cultivation of taste in nineteenth-century 
America. These lectures complemented the Association's prized plaster cast collection and fit the civic ambitions of the founding trustees and members, which Prudence Roberts has described as "Heritage in the Making."

These topics also resonated with other Progressive Era agendas and allowed the Association to connect with and host other civic-minded community groups. The diversity of groups created an eclectic annual program on art with explicit civic themes. During the school year 1912-1913, for example, the Archaeological Society offered lectures such as Excavations in Crete; Rome, the City Beautiful; and Pictographic Scripts of the Ancients. In addition, the Collegiate Alumni Association presented sessions on the civic value of playgrounds and instructors from Reed College offered an entire community course on Education and the Citizen. Presentations on civic topics and civilization history also provided opportunities for special receptions for and meetings by groups such as the Greater Portland Plans Association, the Progress Club, the Business Girls' Club, the Ladd School Girls' Club, the YMCA, and even a series of talks for Portland streetcar workers and their families. The Association had become a more active and recognized cultural center for the community than at any point before. ${ }^{32}$

The number and scope of temporary exhibits increased significantly following the opening of the Art School. Previously, the Association had principally drawn on the collections and connections of its trustees and wealthy supporters to mount exhibits. Certainly, the private collections of families such as 
the Ayers, Ladds, Careys, Corbetts, and Hirsches, as well as those of the Failings and Wood, to name just some of the most prominent local collectors, regularly continued to provide the Museum's fare of temporary exhibits. In addition, however, the PAA exhibited more work created by Portlanders, which represented a significant increase in the number and type of artworks on display in the Association galleries. First, the Art School student exhibit became an annual event from the Art School's inaugural year onwards. Second, Art School instructors regularly presented their work in the Museum gallery. Third, the Association continued to host at least one exhibit of work by members of the Portland Arts and Crafts Society almost every year until the late 1920s. Finally, the efforts of students from local schools were displayed, including exhibits for pupils from Portland's public schools and St. Mary's Academy. ${ }^{33}$ These exhibitions showcased both the success of the Art School's instructional studio program for adult Portlanders as well as the Association's expansive educational outreach to the schools. ${ }^{34}$ Crocker was quick to counter suspicions of local boosterism and aesthetic parochialism regarding the exhibiting of work by local artists. Referring to the artwork of children and youth, she pointed out that such exhibits stimulated the art interests of children, parents, and teachers.

Furthermore, she pointed to the growing interest in contemporary work across the United States, including even the East's most revered art museums with extensive collections of canonical pieces. Finally, Crocker insisted that aesthetic standards had to be met in all of the Association's exhibits: "Not to transgress the 
true functions of an art museum, such exhibitions are only permissible when local work has reached a certain standard." ${ }^{, 35}$

This locally focused and inclusive curatorial programming did not exhaust the Association's new efforts. Rather, the newly founded Art School encouraged professionalism in the content and conduct of exhibitions and other activities. This was especially evident in the contemporary art and lectures, which now were regularly part of Association programs. Barely a year into her curatorship at the Association, Crocker secured an exhibit from New York's Macbeth Gallery, which had previously loaned seven works by Arthur B. Davies to the Lewis and Clark Exposition. As one of the earliest champions of contemporary American art, the Macbeth Gallery had a critical impact on the development of modernist art in the United States in the early twentieth century. The Gallery is particularly recognized in American art and cultural history because it hosted an exhibit by what the group known as "The Eight" in 1908. This landmark event in American art featured the work of eight contemporary American painters. Five of those, John Sloan, Robert Henri, William Glackens, George Luks, and Everett Shinn, are known today for their association with the so-called Ashcan School, which sought to capture the urban realities of early twentieth-century America. For the exhibit at the PAA in late 1910, William Macbeth selected figure drawings and twelve paintings from Davies, a member associated with The Eight and post-impressionist American artists represented by Macbeth Gallery. This was the first in a series of exhibits that came from the 
Gallery to the PAA as a result of Crocker's solicitation. These and other exhibits introduced the Portland public to innovative work in the visual arts, including the work of other artists from The Eight. ${ }^{36}$

Art historian Faith Emerson has traced the passionate promotion and the regular collecting of contemporary work by Association benefactor Sally Lewis to these early exhibits by the Macbeth Gallery. Lewis's life-long advocacy and sponsorship of contemporary art as well as her energetic collaboration with Crocker provide the key elements of Emerson's thesis “Modern Art Hits Stumptown" (1997). Lewis's connections with East Coast and European art centers supplied the Association with some of the most exemplary contemporary work. Among the avant-garde works Lewis brought to the Association and Portland is Constantin Brancusi's sculpture Muse (1918) which was controversial at the time and is now part of the Portland Art Museum's permanent collection. ${ }^{37}$ Exhibits of that kind mobilized other Association trustees and supporters as well. Certainly, an increasing number of them advocated for contemporary art, which previously had been limited to a few individuals such as Wood and his promotion of American Impressionist painters. In fact, a group of over sixty subscribers purchased a marine scene by Paul Dougherty out of the second Macbeth exhibit on loan to the Museum during the summer of 1911, only the second original artwork in the Museum collection at the time after Hassam's Afternoon Sky. Even though the Macbeth loan exhibit did not include avant-garde work, it was nevertheless a notable foray for the Association into contemporary work, which 
reflected national, if not international, trends in painting. Crocker billed it as the highlight of the Museum year because it presented work by prominent American painters, active either at the time or in the recent past, including La Farge, Sartain, Inness, and Whistler. ${ }^{38}$ Exhibits of contemporary and even avant-garde artworks created a forum for lectures and discussions beyond the predominantly historically minded presentations of previous years. For example, Frederic C. Torrey, who was a partner in the a San Francisco interior design firm and art gallery Vickery, Atkins, and Torrey, lectured occasionally at the Association. Torrey had already advised in the planning of the Fine Art Exhibit of the Lewis and Clark Centennial Exposition. Following the opening of the Art School, Torrey curated exhibits of contemporary art on loan at the Museum from his gallery or his clients, and concurrent with these exhibits, lectured on the works on display, their creators, and general developments in modern and avant-garde art. $^{39}$

The Art School teachers and staff also found the presence of contemporary artworks a platform for investigating new ideas and forms in the arts. Crocker in particular frequently addressed contemporary issues in art and art education in lectures on modern artists and art movements. Her lecture series during the Art School's inaugural year, "Understanding Painting and Sculpture," departed from the historical and civilization categories with which art and art history had previously been investigated and presented at the Association. In the place of vistas of ancient pasts and civilizations, Crocker's discussions reflected 
had titles such as "What is Art? The Meaning of Design, Harmony, Balance, Rhythm," "Abstract Qualities of Painting and Sculpture," or "The Technical Elements of Painting and Sculpture.” Even when discussing traditional categories of art and culture, Crocker's educational approach privileged a new cultural relativism over the older essentialist comparisons. Lectures such as "Ways of Seeing," which used cultural comparisons "to show us more clearly our own conventions" drew at least in part on new professional theories about the historical contingency of perception and interpretation of cultural artifacts. The management and direction of the Art School demanded that the educational service be up-to-date and allow for competing views on art and art education. Crocker's personal art studies of the preceding decades had made her a wellinformed student of the arts, including its contemporary and theoretical developments, her lack of formal academy training notwithstanding. Her personal attributes and her passionate commitment to excellence in art and art education made her the Association's transformative leader, for which she continued to be recognized for decades. ${ }^{40}$

Crocker tapped into the rapidly emerging and expanding network of professional individuals, associations, and publications in the arts and art education. If the post-bellum era had brought about the founding of many of America's most noted art museums, the early twentieth century saw a surge in the founding of professional arts organizations. Notable among these were the American Association of Museums (1906), the American Federation of the Arts 
(1909), the College Art Association (1911), and the Association of Art Museum Directors (1916). These networks provided up-to-date information and publications, and created access to travelling lecturers and exhibitions through shared sponsorships. This was particularly significant for art organizations in the American provinces, which had found it difficult to afford or at times even connect with individuals and artifacts from cosmopolitan arenas, save for the occasional personal connection of a local patron and philanthropist. The growing number of professional publications in art, art education, and museum management accelerated the circulation and exchange of information among art institutions across the United States. Nationally distributed publications served the new cadre of professionals who were taking leadership roles in the various art and art education institutions. The Association subscribed to reports of the Metropolitan Museum of New York, the Boston Museum of Fine Arts, the Chicago Art Institute, the City Museum of St. Louis, the Detroit Museum of Art, and others. Regular periodical subscriptions included The American Journal of Archaeology, Handicraft, International Studio, and Progress and Art, all wellknown and nationally recognized publications at that time..$^{41}$

Organizational networks also expanded access to artworks and created new exhibition opportunities. In addition to loans from Macbeth and Torrey, Crocker regularly tapped into travelling exhibits organized by the American Federation of the Arts. She also secured exhibits of student work from other institutions, including an early loan from the Cincinnati Art Academy in $1911 .{ }^{42}$ 
Furthermore, Crocker engaged leading art educators as visiting lecturers through these networks. DuMond, who had played such a prominent role in the Centennial Exhibition, returned from the Art Students League in New York for a public lecture and critique of work by Art School students during the late summer of 1911. Frank Logan, leading administrator at the University of Chicago, spoke on modern art later that year. Leading voices associated with the Arts and Crafts movement also lectured at the Museum, including Charles Robert Ashbee and Ernest A. Batchelder. The same year also brought a visit and address by progressive art education advocate Henry Turner Bailey. Bailey's professional portfolio was certainly a perfect fit for the Association. At the time of his visit to Portland, Bailey was the editor of the journal School Art Book, the leading publication promoting the study and appreciation of art in primary and secondary American education. At the end of the school year 1911-1912, the Association could boast of having delivered a total of ninety-nine lectures to its students and the general public. Certainly, these activities did not represent a wholesale endorsement of modernist, let alone avant-garde, work and ideas. Nevertheless, the new exhibits and presenters created a steady presence for contemporary concerns in the arts. ${ }^{43}$

By tapping into the emerging professional field nationally, the Association had significantly transcended its previous dependence on the volunteerism and relationships of its local supporters and trustees for program presenters and materials. Indeed, the launching of the Art School fundamentally 
changed the roles and requirements of the Association's trustees and expanded active membership. Rather than organizing and, in some cases, providing direct services as trustees had done in the absence of Association staff, trusteeship now focused more narrowly on governance and fundraising. In many respects, this change represented a professionalization of trustee service, resembling much more the standard type of volunteer and philanthropic advocacy of American cultural organizations in the twentieth century. By the end of 1909, for example, the Association had created five standing committees, which not only widened the circle of decision makers within the organization but also prescribed specific areas of responsibility. Committees were formed on the Art School, Finance, House and Collections, Exhibitions and Lectures, and Membership. ${ }^{44}$

Above all, fundraising became an ongoing expectation and responsibility, certainly for the senior trustees. Trustee financial donations sustained the educational services of the Association. Hoffman, who had funded in full the PAA's first teaching position, continued to make significant contributions, including the funds for the annual Arts and Crafts student scholarship. Eliot was indefatigable in widening the circle of donors among Portland business families. A particular goal was the completion of Corbett's $\$ 50,000$ challenge grant. Interest from this endowment was rightly seen as the Association's most promising source of stable income. Despite the economic challenges in Portland during the World War I, the matching funds were secured during the school year 1916-1917. ${ }^{45}$ Eliot, acting president of the PAA, captured the change of the 
Association and exalted the growth of art instruction and aesthetic education three years after the Art School's opening:

From a beginning when the Trustees for some time were simply a holding power, entrusted with certain present and intended gifts, through years when for a few hours a week a gallery of sculpture and cases of photographs were open without comment to a limited public, we have now attained to active life, in a beautiful permanent home with manifold activities and outreachings into the currents of society. True, the scale is not large, but the quality of work and influence in each department is excellent and the type is set so high that every increase of means and of effort will be a truer education and uplifting influence to students and the whole community. Every year also finds the Art Association nearer to the heart of the whole people, with a feeling of ownership by them, which gives us profound satisfactions. ${ }^{46}$

We need not agree fully with his claims about the elevated "quality" and "influence" of the Association's work, at least not in regard to professional fine art practice and commodities. In his preface to a catalogue on the Art of the Pacific Northwest (1974), which took the 1930s as its starting point, art historian Joshua Taylor provided a gracious description about the aesthetic and cultural aspirations and limitations of the region and, especially, of its two urban centers, Portland and Seattle: "There was no ignorance about art," suggested Taylor, who had attended the Art School in the mid-1930s, but "art was in no sense wholesale." ${ }^{\prime 4}$ The PAA's work should not be dismissed as outdated or amateurish simply because of the absence of nationally recognized artists and artworks.

Rather, the PAA focused on current and professional ideas and practices in art education and it also attended to newly emerging fine art and artists. The Association developed within the stream of Progressive Era education, institution building, and social reconstruction. The formation of a Museum and, shortly 
thereafter, an Art School confirms a pattern for joint operation of art school and art museum that art historian Joyce Woelfle Lehman observes across turn-of-thecentury America. Lehman identifies this new organizational form as a "hybrid institution" to emphasize its difference in purpose and structure from standard notions of art academies and art museums because it embodied an enthusiasm for popular art museum and art instruction programs. ${ }^{48}$ Indeed, art museum and education efforts were underway at the Worcester Art Museum in Massachusetts, the Syracuse Museum of Fine Art in New York, the Corcoran Gallery of Art in Baltimore, the Toledo Museum of Art in Ohio, the Art Association of Richmond in Indiana, and the St. Louis Museum and School of Fine Art in Missouri. If Portland and its provincial sister cities did not come close to matching the scope of and investment in collection building at the art institutions in national centers of Boston, New York, Chicago, and San Francisco, the art enthusiasm and its democratic appeal were all the more ardent. Thus, in 1915, Crocker justifiably emphasized that all of the Association's efforts ought to be recognized as "educational work.",49 


\section{Chapter 5: Becoming the Museum Art School}

Throughout the 1910s and most of the 1920s, the Art School was the center of activity at the Portland Art Association; it continued to focus on art education and art appreciation, rather than collection and endowment building. Museum exhibits and lectures increased in frequency and diversity, including contemporary works and ideas in visual art, with the primary goal of art education. The Art School expanded both its studio instruction program and its service to Portland public schools. At this time, Anna Belle Crocker sought to formalize degree certification in art education for Art School graduates in order to fulfill the promise of professional preparation. Courses already addressed vocational concerns for selected arts-related professions such as illustration, architecture, and various artisanal practices either through general design and fine arts classes or, more prominently, through material-specific crafts instruction. However, Crocker recognized art teacher training as the most promising opportunity to provide graduates with complete career preparation. After all, art education training complemented perfectly the Association's work with Portland public schools. Attuned to current developments in art and art education, the organization's activities of the period reaffirmed a strong commitment to service to the general public and an identity as a key civic institution within the Portland community. Significant efforts for collection and facility expansion emerged only in the late 1920s. Their quick and ambitious 
realization, coinciding with the onset of the Great Depression, considerably realigned the priorities of the Association.

Enrollment in the Art School's studio program exceeded one hundred students in virtually every year during the 1910s and 1920s. The highest enrollment count came in 1915-1916, when 132 students attended at least one course during the school year. The most significant enrollment gains, however, resulted from students taking multiple classes concurrently and pursuing the completion of the Art School's certificate of study. Throughout most of the period, the Association emphasized the vocational benefits of Art School attendance. The program's "students found work," as Crocker pointed out, "in various branches of minor art, such as lettering, drafting, cartooning, decorating, designing and executing textiles, block printing, embroideries, pottery, etc."1

The claim of training and career preparation evidenced, or at least aimed to demonstrate, several key elements in the organization's operations. First, job training promised better income for community members and hence affirmed the Association's service to the population at large. Second, vocational claims resonated with the artisans associated with the arts and crafts. Their presence remained a constant in the Association well into the 1930s as artisans enrolled in Art School classes and exhibited their work at the Museum. In fact, Julia Hoffman, who had funded the Art School's first teaching position, continued to provide the Association with significant financial support throughout both decades. Third, the service to industry was highlighted in the trustees' 
fundraising appeals to the Portland business community. In fact, the balance in vocational preparation on the one hand and fine art education on the other bestowed, at least in the Association's view, a special identity. Rather than a masterful academy, Crocker suggested that the program's "peculiar quality is seen to be its close union of the necessary technical training with spirited design and composition," which, far from representing mere provincialism, signified "a distinct and important character among the art schools of the country."2 Certainly, reference to vocational preparation suppressed elitist connotations of art and art education such as the conflation of the Art School with a finishing school or highbrow aestheticism limited to the rich would have fostered.

Crocker, however, recognized teaching as a profession for which the Art School promised to prepare its graduates most specifically and comprehensively. In fact, while the School added new classes to its program almost every year, including illustration, design, and various craft media, the opportunity for practice teaching represented the most significant addition, at least for students with an interest in teaching and pursuing the completion of the three-year certificate of study. Once they had advanced in their course studies, students interested in a teaching career could do classroom observation and teaching in the Art School's introductory adult courses and in the children's classes. Furthermore, the Association had an arrangement with Portland public schools which allowed Art School students to complete their practice teaching in a public classroom. Indeed, the most of the earliest graduates went on to teach in schools. Interestingly, they did not simply seek teaching opportunities in 
Portland or in rural Oregon, but instead took up positions as far away as Duluth, Minnesota and Chicago. ${ }^{3}$

Teacher employment in early twentieth-century America increased rapidly due to the growth in primary and secondary school attendance and especially in art and handicraft education. Yet Foster Wygant reports that teacher training, especially for art and for craft, was still in its infancy and formal education of teachers often limited except in the nation's better city systems. ${ }^{4}$ Hence, Crocker sought to have the Art School program approved as an art teacher training program that granted an official teaching endorsement. The opportunity seemed to be promising in the 1910s because the study of art and art history at Oregon colleges and universities was far from institutionalized. While Willamette University had offered the first art course at an Oregon college as early as 1860 , early twentieth century post-secondary educational institutions, including Oregon's Normal School (today Western Oregon State University) did not have studio art instruction programs on a scale comparable to the Association's Art School. ${ }^{5}$ Recognizing the need for liberal arts studies in the education of future teachers, Crocker pursued collaboration with Portland's newly founded Reed College. Jointly, the two small institutions sought to provide a comprehensive program for teacher training and receive state accreditation. However, in a letter to Reed President William T. Foster in June 1917, Crocker admitted her disappointment that the state superintendent had rejected the proposal, which would have allowed Art School students to meet the state's 
teaching requirements through course work at Reed College. Yet Crocker decided "to confine the pedagogical work to what we can do here and the practice work," and continued her advocacy for a teacher preparation program. ${ }^{6}$ A decade later, Crocker's effort to establish an accredited program would finally prove successful.

The growth of the Art School required the hiring of additional instructors. In preparation for new classes and higher enrollments in the Art School's second year in 1910-1911, Crocker hired Henry (Harry) Frederick Wentz, with whom she was well acquainted from joint membership in the Portland Sketch Club, where they had shared studio studies. At the time of his hiring, Wentz held the instructor position for manual training at Portland's East Side High School, later known as Washington High School, and his school experience made him a perfect candidate for an instructional position with the Art School. Wentz was a native of The Dalles, Oregon, and his own educational path reflected a variety of experiences typical of the time. These included studio study in association with like-minded peers such as the Portland Sketch Club and the Oregon Art Students League, and attendance at more formal art institutions such as the New York Art Students League, Columbia University's Teachers College, and the Lyme School in Connecticut, where Wentz studied with Frank Vincent DuMond and Arthur Wesley Dow.

Wentz's influence on a generation of Portland artists can hardly be overstated. His dedication to the learning and success of artists and artisans, 
inside and outside the classroom, was legendary. At the Art School, he was an instructor of both adult and youth classes. Importantly, Wentz taught traditional fine art classes as well as design and craft-related subjects and materials throughout his extraordinary tenure at the Art School, which ended in 1941. Like Crocker and Failing, he had an appreciation for and strong ties to the Arts and Crafts movement. For example, Wentz chaired, at the invitation of Julia Hoffman, the discussion and critique meetings of Portland artisans during the 1920s. After all, Wentz had been a manual arts instructor in Portland Public Schools and, furthermore, had worked professionally as a woodcarver and interior designer. In fact, he contributed the Turkish smoking room, with its painted ceiling and Tiffany glazes, to Portland's Pittock Mansion, built by Oregonian publisher Henry Pittock and his wife Georgina. ${ }^{8}$

Leta Marietta Kennedy and Clara Jane Stephens were two other Art School instructors who shaped the instructional program during the Art School's first decades. Their appointments began in the mid-1910s and spanned several decades. Pendleton-born Kennedy attended the Art School in 1917 and 1918 and also taught children's classes during that time. She completed her teaching certificate at Columbia University and assumed a faculty position with the Association in 1922, which began a lasting pattern of Art School graduates returning as teachers after further study at the main New York institutions of art education. Although Stephens stood out, today she is rarely recognized for her prolific, more than half-century long painting career. Transplanted from England 
to Portland just before coming of age, Stephens had first taken art classes from Eva Woolfolk, who had been active in the Oregon Art Association and the Portland Sketch Club. Similar to Crocker, Wentz, and other Portland artists, Stephens moved from local mentorship to study at the New York Art Students League, taking classes there with DuMond and Kenyon Cox. She also visited Europe and attended a summer course in Italy with William Merritt Chase. At the Art School, Stephens taught children and adult studio courses until her retirement in $1938 .{ }^{9}$

With growing course enrollment and increased staffing, the Art School anchored a new community of Portland's art-minded individuals. The Art School created a first, enduring organizational center for art professionals in Portland, which extended beyond those employed at the Association. Central to this community were the leadership and friendship of Crocker and Wentz. Deservedly, the Portland Art Commission recognized them in 1959, the State's centennial year, with a joint award for their distinguished service. ${ }^{10}$ Crocker's and Wentz's efforts reached the larger community because of their ongoing collaborations with various organizations, including Portland Public Schools, the County Library, as well as various artistic and civic associations and groups. Joining Crocker and Wentz as a highly successful professional was Albert E. Doyle, who served as an Association trustee from 1917 to 1928 and, during the last two of these years, as PAA president. Philip Niles describes Doyle's unexpected and remarkable career as Portland's foremost architect in Beauty of 
the City: A. E. Doyle, Portland's Architect (2008). Growing up in rather disadvantaged circumstances in Portland, Doyle apprenticed in the architectural firm of Whidden \& Lewis, one of Portland's premier businesses at the time. While Doyle's achievements were exceptionally successful, they nevertheless exemplified the arts-related professional opportunities available in earlytwentieth century America, especially in a burgeoning provincial city such as Portland. Doyle enjoyed a particularly close friendship with Wentz, on whom he sometimes called for artistic drafting and illustrations when his architectural firm needed help. ${ }^{11}$

The Art School students further widened the circle of community. While students enjoyed the camaraderie of the classroom studio and the annual exhibitions of their work at the Museum, sociability was not limited to the shared educational experience. For many years, for example, the holiday costume ball represented an annual community highlight, connecting Art School students, teachers, Association members, and individuals from the community at large. A student performance in 1915 provided not only entertainment but also a clever commentary on contemporary art. Described as an artistic vaudeville in four numbers and titled "Modern Tendencies, Moving and Stationary Pictures, Morning in an Art Shop," the performance drew attention to the most controversial artists' names and artistic styles as well as to the market place for fine art at the time. The four staged scenes reflected curiosity about the latest avant-garde artworks as well as their contested reception. According to a 
description at the time, "Portraits are displayed, provoking various emotions. A Matisse creates excitement and is purchased. A Van Gogh produces acute rage, and a Cubist painting is almost disastrous. The dealer, in despair, telephones for the artist, who enters and, by compelling influence, effects a sale."12 The point here is not to claim an endorsement or rejection of avant-garde art at the Association, but to suggest its serious consideration. Finally, Portland historian Michael Munk suggests the existence at the time of a small bohemia in Portland with the Art School at its center. Munk's essay on Helen Lawrence Walters, a young artist active in the 1910s, and her husband Carl Walters, reports her attendance and appreciation of events organized by Art School students. Such activities regularly enjoyed the support and participation of Association instructors and trustees as well as arts-minded community members such as Walters. ${ }^{13}$

The impact of the Art School on the Association as a whole was strongly felt in the exhibition program, which no longer relied predominantly on exhibit loans and facilitation by trustees. First, the artworks of Art School instructors and students as well as community artists and youth provided regular exhibition material for the Museum. Second, exhibits throughout the 1910s and 1920s displayed an eclectic range of images and objects including canonical and avantgarde artworks, children's art, decorative arts and handicraft, city planning documents, and antique and anthropological objects. Third, the Association galleries continued to show rugs and wall hangings, textiles, pottery, metal 
wares, Asian and African art, American Indian artifacts, and a broad assortment of utilitarian and anthropological objects. The most noted novelty in the exhibitions, however, was the occasional, yet regular, presentation of avant-garde artwork. An early example of Crocker's educational and curatorial interest in avant-garde art was the 1913 exhibition of Marcel Duchamp's The Nude Descending the Staircase, No. 2 (1912). Duchamp's painting had been the pièce d'éclat of the International Exhibition of Modern Art, better known as the Armory Show, which had been held at New York City's National Guard Armory in February and March of 1913 and introduced the work of Europe's foremost modern artists to American audiences. Even before the exhibit traveled to Boston and Chicago, it was seen by approximately 275,000 people during its month on display in New York alone. San Francisco art dealer Frederick C. Torrey purchased Duchamp's painting along with other works from the exhibition, reportedly unseen. In December 1913, the painting went on exhibit at the Association in the company of prints and photographs of European masterworks selected by Torrey, including El Greco, Courbet, Cézanne, Matisse, Picasso, and others. At the opening of the exhibit in the Association's Museum, Torrey lectured on "The Significance of Certain Tendencies in Modern Art." ${ }^{14}$

Crocker was well aware of the controversy and notoriety surrounding the avant-garde works in the Armory exhibit, especially those by Duchamp, Matisse, and Picasso. Sure enough, as the Torrey loans of the Armory Show artworks went on display at the Museum, an Oregonian headline referred to Duchamp's 
painting as “'Picture' Resembles Wrecked Shingle Mill."15 Crocker observed that Museum visitors "burst into audible and visible rage" when viewing the painting and reported the loss of a few Association members over the exhibit. ${ }^{16}$ For Crocker, such reactions confirmed the importance of art in human affairs and revealed that art touched "the whole range of feeling and thought."17

Furthermore, the strength of such reactions demonstrated, in Crocker's view, the danger of convention in art and of habitualization in art appreciation and even in perception.

Crocker insisted on the viewer's independence in aesthetic judgment. She despaired of the conventional critique that dismissed Duchamp's painting and other artistic innovations simply because they failed to meet accepted standards of taste and tradition. Convention and conformity were all the more in evidence in objections to Duchamp's work because of, so thought Crocker, the painting's mild palette and negligible subject matter. In order to highlight the seeming contradiction between the painting's unremarkable form and content on the one hand and its notorious violation of artistic tradition and cultural code on the other, Crocker decided on an intriguing curatorial strategy. For the Association exhibit, Crocker hung the Duchamp painting with "a dull blue cloth behind it [in order] to distinguish its ivory, tan, beige and olive from the neutral colored walls." ${ }^{18}$ Her intent was not simply to highlight the painting or, granting her a Duchampian attitude, to distinguish the painting from the gallery wall decoration. Instead, Crocker wanted to activate the painting as a painted canvas rather than a 
cultural spectacle. Furthermore, Crocker challenged the viewer to arrive at a personal decision as to the painting's merits and demerits, insisting on the autonomy of personal judgment. Correspondingly, Crocker invoked the Association's responsibility in educating and preparing Portland's citizens to make such judgments equipped with the necessary understanding, free from conventions, fashions, and obscurantist or iconoclastic attitudes.

Crocker's curatorial maneuver and commentary regarding the presentation of Nude Descending a Staircase, No. 2 highlighted her aesthetic and philosophical position and reflected the educational and cultural sentiments prevailing at the Association in the early decades of the twentieth century. Such thinking entailed a set of overlapping assumptions. First, an artwork embodied aesthetic value, and hence its success or failure was contained within it and could be seen in the object or image. Second, an artwork's qualities ought to be visible and appreciable even to the untrained eye, at least to some degree. Third, every person was endowed with a fundamental, aesthetic capacity; hence, education could not only cultivate one's aesthetic sensibility but, importantly, all citizens deserved a comprehensive aesthetic education. Fourth, the existence of a hierarchy in artistic accomplishment required judgment by a discerning citizen. Finally, artistic practice and appreciation ought not to become an elitist province, whether that of the wealthy or that of aesthetes. Above all, Crocker desired to balance hierarchies of artistic values and practices with democratic access and appreciation of aesthetic standards. In her writings, she exalted the "fireman of a 
switching locomotive," who diligently attends evening courses at the Art School to further his aesthetic understanding over the "lady in modern dress," who disdains all but conventionally sanctioned art, while unwittingly putting modernism on display in her attire. ${ }^{19}$

Scholarship on the Association's early history has emphasized the presence of avant-garde artworks over that of other pieces and has largely ignored the bulk of organizational activities. Admittedly, this early encounter with avant-garde art was certainly a surprising element in the organization's early development. Similarly, Crocker has been lauded for her presumed advocacy of modernist and non-traditional art forms. This emphasis, I suggest, attributes an exaggerated level of endorsement and promotion of avant-garde art within Association activities during the time. Indeed, Crocker cautioned about the dangers of convention in avant-garde art. "We did not, then," reflected Crocker in her memoir, "see how easily (the new being no more proof against 'disjunction' of manner and matter, superficiality and imitation, than the old) this novelty could slide into a less heavy and dry but also less disciplined sort of academicism." ${ }^{20}$ Her comments suggest that a qualified, instructional endorsement of innovative art forms was operative at the Association, rather than a wholesale acceptance of modern, let alone avant-garde, practices and styles.

While Crocker's advocacy for avant-garde art has been overly estimated, the centrality of Benedetto Croce's philosophical work in her thinking has not received any attention at all. In part, this omission is surely the result of the 
disappearance of Croce and his influence from critical discourses in art and philosophy during the second half of the twentieth century. Earlier in the century, however, Croce was one of the most recognized European philosophers in the United States, where his Aesthetic (1902) was widely circulated and influential until the 1950s. In fact, historian Gary Kemp suggests that Croce's Aesthetic was the most celebrated work of its time on the subject. "Croce's original Aesthetic was," according to historian George H. Douglas, "a contribution to a theory of human experience more than it was an elaboration of a detailed philosophy of art; his theory of intuition-expression was an attempt to show the inseparability of the experience of the artist from ordinary experience." ${ }^{21}$ The claim of a universality in the quality of aesthetic experience and the continuity between pedestrian and artistic perception resounded with Crocker, whose writings were replete with references to Croce and whose philosophical writings she credited as her road map. Additionally, Croce's elaboration of the creative or constructive role of the knower in cognition and the singularity, and even autonomy, of individual perception reverberated with her. Certainly, Croce's epistemological and philosophical arguments shared similar concerns and values with American pragmatism, especially with the work of John Dewey. Finally, Croce's slip into obscurity resulted from his too broad repertoire, a seemingly baroque idiom, and, as far as aesthetics were concerned, a lack of specificity in subjects and categories. By mid-century, Croce's aesthetics was a mere reminder of a past that had been overtaken. While certainly a minor figure compared with Croce, 
Crocker and her writings shared much of these attributes. It is therefore hardly surprising that Crocker's work, except for her resolute inquiry into and curatorial interest in avant-garde art, has been relegated to an unusable past. ${ }^{22}$

The field of art education underwent a modernist transformation equally foundational in scale but less widely recognized than the iconography of modernist innovation and revolution in art. The revision of ideas and processes in art education had a notable impact on Art School programs. The educational work of Dow, the leading American arts educator in early-twentieth-century America, highlighted the changes and the new ambitions in American arts education. His art pedagogical publications, Composition (1899) and The Theory and Practice of Teaching Art (1908), were standard texts in their field. The summer school in Ipswich, Connecticut, which Dow founded and ran from 1900 to 1907 , explored the artistic elements in handicraft and manual training and their proper development in art education. He also taught at New York's Pratt Institute, before being appointed as the director of the art department at Columbia University's Teachers' College in 1904. In his position at the Teachers College and as a nationally active speaker and workshop leader, Dow influenced a generation of American artists, especially, art educators, including those at the Association. In fact, Crocker and the Art School teachers not only applied his aesthetic and pedagogical ideas, but several of them had studied with Dow at Columbia University to further their own education. Not surprisingly, the Association recruited Dow to conduct summer classes on design, normal art, and 
handicraft during the summer of 1917. Anticipation of Dow's summer class ran high at the Association, as his visit marked the culmination of the various and still relatively new Art School programs. Dunlap, the school docent, had just completed her second year as the official liaison with Portland public schools, advanced students in the Art School had begun their first student teaching, and Crocker was in the midst of applying for state certification of a teacher training $\operatorname{program}^{23}$

In preparation for Dow's visit, Crocker gave a series of four talks in October and November of 1916 covering Dow's so-called theory of art structure. Dow proposed that art and art education focus first on the formal elements rather than on representational techniques and content. He referred to his approach as art structure to differentiate it from the traditional art educational model that had privileged imitation, whether by copying from nature or from historical forms and styles. Dow identified three formal elements - line, color, and "notan" (a Japanese term for contrasts in pictorial value) - as the foundation of design, in both fine and decorative arts. The resulting abstraction in pictorial representation in turn challenged traditional models (and privileges) of the fine arts academy and its emphasis on modeling and imitation. ${ }^{24}$

Certainly, Dow's leveling of art education hierarchies and his insistence on a universal method of aesthetic education represented a significant departure from institutionalized forms of art instruction. Indeed, Dow despaired of his earlier academic studies, especially "the years spent in the Académie Julian 
where we were taught by professors who we revered, to make maps of human bodies." 25 Dow's art structure made a critical change in art education, shifting the focus from mapping the human site to mapping human sight. In Dow's view, a new science of perception replaced the dated systematics of historical imitations and conventions. Dow's claims recall the names of his near contemporaries, including the today much more prominent European innovators of art education such as Roger Fry and the leading artists of the Bauhaus.

Dow's workshop, which covered design, normal art, and handicraft at the Art School during the summer of 1917, was a resounding success, drawing ninety-seven participants, principally from the West Coast but also individuals from as far away as New York, New Jersey, and Ohio. To coincide with Dow's workshop, Crocker also curated a sizable exhibition of Japanese prints complemented by Japanese artifacts, for which Crocker drew on the collections of trustee families. She also made arrangements for Dow to meet local collectors who valued Dow's expertise in Japanese art and design. Finally, Dow presented illustrations of art and art education work done in Eastern schools, especially the practice of "Picture Study," which enjoyed extraordinary popularity in the Portland community and elsewhere at the time. Dow criticized the use of reproductions in education for moralistic ends, however. Instead, he insisted that, first, only artistically successful compositions were to be used in reproduction and, second, students' attention be drawn primarily to the design elements, and not the subject matter and propriety, of a composition. ${ }^{26}$ 
Dow's ideas about art, art education, and art appreciation bridged multiple divides, which made them conducive to the particular educational commitments and the mandate for serving the general public at the Association. While he did not deny the differences among the respective métiers, Dow nevertheless posited a shared foundation for training in the fine arts and in the decorative arts. Dow's aesthetic and art educational propositions bridged the gap between "mere" technical training and "higher" fine art study and instead claimed a unity and, in many respects, universality of artistic production. Furthermore, like Crocker and Croce, Dow posited continuity between a nonprofessional appreciation of artworks and the professional production of such art, irrespective of differences and hierarchies of value and accomplishment. Hence, he not only sought to inoculate art and artistic practice against specialization and, worse, elitist realms of human experience, but also asserted a central place for art education in general education. $^{27}$

Shortly after Dow's visit, the Art School offered a course in occupational therapy training, especially for the rehabilitation of veterans returning from the European battlefield. Although its impetus was historical circumstance and not ideology, this course nevertheless represented the perfect deployment of art education in the service of vocational and civic ends. Indeed, when Crocker discussed the course, she emphasized that the training of students as well as the service to the disabled veterans would "make evident the real value of the artistic instincts.",28 Furthermore, Crocker shared her agreement about "the value of art in life aside from 
the finished product," when she invited prominent Portland physician Edmund J. Labbe to speak at an exhibit of children's classes. "This is something that touches us closely," asserted Crocker, "and we want to use that value particularly with children and cripples, as well as for all people who find that it fulfills a need within them." 29 Following the completion of the course, the annual Association report of 1919 similarly boasted the social benefits of this endeavor, suggesting that the year-long course was "believed to be but the beginning of a still wider use of handicraft as a therapeutic and social agent in reconstructions. ${ }^{, 30}$ This particular effort in occupational therapy was emblematic of the Association's imperative of art education for the general public and for reconstructive ends in art education. The Art School's emphasis on service rather than on specialist knowledge and training reflected general Progressive Era ambitions for social reconstruction, in particular the aesthetic ideas of Dewey and the work of Addams and Starr at Chicago's Hull House.

Indeed, the teaching of children remained at the center of Art School activities in the 1920s. Association publications proudly reported museum attendance of several thousand school children each year, adding that this number did not include several thousand more children served by the school docent and circulating Association materials. Each year also brought special activities focused on the education of children. In another collaboration with the Portland School Art League, the Museum hosted a presentation series on art- and art education-related topics, which had been produced for the American Federation of Arts by the nation's most prominent art education institutions, 
including the Museum of Fine Arts, Boston, the Chicago Public School Art Society, the Art Institute of Chicago, and the Metropolitan Museum of Art. ${ }^{31}$ The artwork of precocious child artist Pamela Bianco was exhibited and provided the occasion for a lecture by Portland clinician C. S. Kohs about the psychology of children's art. ${ }^{32}$

Special exhibits at the Museum were curated specifically for children and included children's book illustrations from European countries. Furthermore, the Museum also showed an increasing number of exhibits of work by children. In 1925, a travelling exhibition of the Western Association of Art Museums brought children's artwork from the school of Austrian art educator Franz Cizek. Historian Arthur Efland credits Cizek as "the first to claim that art made by children had intrinsic value" and points out that his concept of children's special art capacity perfectly matched American educators' enthusiasm for a new, childcentered pedagogy known as "creative self-expression." ${ }^{33}$ The exhibit of Cizek students' work set a record for exhibit attendance at the time, drawing almost four thousand spectators to the Art Museum in a single month. ${ }^{34}$ Just two years later, Portland educator May Gay lectured at the Museum on her recent visit to the Cizek School in Vienna and presented examples of her work and of other educators' work with children. In fact, the Art School's own first traveling exhibit of original work by its students consisted of artwork from its youth program. Thirty pieces of work from the Art School children's courses traveled in 1927 and 1928 to art museums in San Diego, Los Angeles, and then to Eastern 
cities. ${ }^{35}$ The following year, a circulating exhibition of schoolwork travelled to art museums in San Diego, Los Angeles, and the East Coast. ${ }^{36}$ In 1927, Crocker included drawings and paintings from children in art programs in Baltimore and in Berkeley, California in an exhibit of work from the Association's own children's classes. ${ }^{37}$

Corresponding to these youth-focused efforts, Crocker resumed her negotiations with Reed College regarding a joint teacher training degree in early 1925. She now approached Reed President Norman R. Coleman with a proposal for a five-year program modeled on recent initiatives elsewhere in the country. A joint program by the Barnes Foundation and Columbia University and a new art teacher program in Cincinnati, Ohio provided new and successful examples to follow. Crocker pointed to the Art School's past and prospective graduates who were not only interested in attaining certification but also found upon graduation that their best chances for employment were in the teaching profession ${ }^{38}$ Later that year, Crocker finalized the curriculum, which followed the structure of her initial proposal, with Reed faculty member Edward O. Sisson. Students seeking teacher certification first completed two years at the Art School, which covered drawing, painting, composition, design, handwork, and art history, with special attention to the broad principles underlying artistic construction and expression. These were followed by two years of study at Reed College, which comprised educational and social science course work and a final fifth year of practice 
teaching. The first student enrolled in the teacher-training program in the fall of $1926 .{ }^{39}$

Crocker continued to exhibit contemporary work by local artists, artisans, and the school's own students and avant-garde work. For example, substantial selections of work by Wassily Kandinsky, Paul Klee, Alexej Jawlensky and Lyonel Feininger, all members of the artist group Der Blaue Reiter, were exhibited at the Association in $1927 .{ }^{40}$ The most remarkable avant-garde art exhibits, however, grew from collaboration between Crocker and long-time Association trustee Sally H. Lewis. Lewis's astonishing art activism and cosmopolitan connections are the focus of Faith Emerson's "Modern Art Hits Stumptown” (1997), which argues, “through Lewis' efforts Portland took the lead in breaking museum barriers towards contemporary art." ${ }^{41}$ One of the most striking examples of Lewis's legacy today is her gift of Constantin Brancusi's sculpture Muse (1918) to the Association. ${ }^{42}$ When the sculpture first arrived in Portland in 1924 as part of an exhibit Lewis had organized, the Oregonian derided the sculpture and its creator in the headline that "This is not an Easter Egg-This is a Modernist Sculpture." ${ }^{\prime 43}$ In other provincial cities, such as Omaha and Kansas City, where Lewis had shown her exhibit prior to bringing it Portland, Muse was actually excluded from display. Lewis wrote Crocker from Kansas City that "[t]hey never have had modern art here, and are interested in it spite of themselves." ${ }^{44}$ 
Throughout the period, the Association's acquisition efforts remained negligible aside from a few purchases by subscription. Crocker, the Art School instructors, as well as Association trustees regularly pleaded for funds to support a consistent collection building strategy. In particular, the instructional staff emphasized the need for original artworks as necessary for the proper education of students in the Art School. "Students of art see in detail the differences in quality between reproductions and originals," suggested Crocker, "and so can make the best use of both." ${ }^{45}$ Crocker also suggested that having quality, original artworks at hand was by no means a self-serving interest of students and instructors or a matter of indulging aesthetes. Quite to the contrary, improved collection quality would increase the general public's benefit in the understanding and appreciation of art and countered philistine sentiments such as the Oregonian expressed about the Brancusi sculpture.

Association trustees, too, were interested in advancing the position of the Museum's collection, a task with which two permanent committees, House and Collections as well as Exhibitions and Lectures, had been charged. Association leadership even formed the Society of Friends of the Art Museum" in 1926 in order to improve funding for exhibitions and collections. The fundraising announcement stated the purpose of the initiative to allow the Art Museum the showing of the best contemporary art." ${ }^{46}$ So that the importance of the endeavor would not be missed, the fundraising appeal continued: "The parent of such societies was the French 'Les Amis du Louvre' who aided that great museum to 
secure works of art which might otherwise leave Paris. In Detroit, Chicago, and other place[s] in America, these societies have done much for their cities." ${ }^{47}$ While this effort generated modest contributions from Association supporters and Portland philanthropists, it would not be until 1937 that the Association had a dedicated collection fund. Indeed, Crocker's sole purchase during her twentyseven-year curatorship was a portfolio of reproductions of watercolors and drawings by Cézanne. These Crocker acquired with insurance reimbursements for Association photographs destroyed by fire while on loan to a school. ${ }^{48}$ While limited in number and in prestige, the few purchases made by subscription on behalf of the Association in the 1910s and 1920s revealed its contributions to what art historian Roger Hull has identified as a intriguing variant in the otherwise much maligned arena of Regionalist Art in twentiethcentury America. In Oregon, Hull suggests, aesthetic sentiments and art organizations largely "avoided the political conservatism of mainstream Regionalism, and adopted a collaborative relationship with modernism."49 Early acquisitions on behalf of the organization included Childe Hassam's Afternoon Sky, Harney Desert (1908), Frank Vincent DuMond's Table Rock (1913), and Harry Wentz's Neah-Kah-Nie (1915). These Impressionist works clearly reference Oregon locations; they were artistically valuable and not simply local favorites acquired to provide local color. Similarly, art historian Joshua C. Taylor observes for the mid-century arts environment of the Pacific Northwest "a disinclination to follow the dominant trends in New York." ${ }^{50}$ Developing local 
and regional identity while aspiring to national standards and quality or, conversely, attending to cosmopolitan art trends without becoming merely imitative of Boston and Paris has been a challenge for any regional center. Taylor suggests that cosmopolitanism and local loyalties have been well balanced and operative in the art communities of the American West throughout the century. Taylor suggests a productive equilibrium, which has lead to an astounding artistic diversity, as "each western city bears a different relationship to the rest of the country" and, I might add, to international developments. ${ }^{51}$

Crocker identified two reasons for upholding artistic standards at the Association. First, she credited Henrietta Failing for having refused gifts to the Museum, including a proposed donation of Western scenes by American painters, from the very founding of the Association. ${ }^{52}$ Second, and more important to Crocker, the Art School had reduced the dangers of triviality of convention and fashion in art, especially regarding exhibitions and collection. “The students' interest in museum objects was," wrote Crocker, "not only more vital in character but also more consistent and diversified than that of other groups." ${ }^{53}$ With a permanent collection fund in later periods, financial considerations and the art market nevertheless influenced collection decisions. Already in 1932, Association president Charles H. Carey pointed out that the Museum would not be able to compete with older and better-endowed museums in the acquisition of works of the old masters and foreign artists of note. In light of this disadvantage, Carey suggested a regionalist approach to collecting, 
specializing "in the acquisition of typical American productions, supplemented by judicious selections of Oriental art, for which our location upon the Pacific Coast gives us a special interest and opportunity." ${ }^{, 54}$

The absence of an endowment for acquisitions did not mean that the Museum collections did not grow during the 1910s and 1920s. In fact, not only loans but also donations to the collection were a regular feature of patronage by Association trustees, their families and friends. However, these donations consisted largely of cultural artifacts, not easel paintings and sculptures. Among them were prints, porcelains, coins, ivory tusks, tiles, textiles, laces, fans, fiber objects, bags, masks, tableware, jars, glasses, and jewelry, rather than recognized artworks or art objects. These objects were not without merit and value, especially selected objects of Asian provenance, such as the Lewis family's Japanese collection..$^{55}$

Such apparent eclecticism reflected the limited number of collecting institutions and their broad collecting mandates at the time. On the one hand, libraries often served in their communities as the significant public collections of fine art, especially in provincial America. On the other, art organizations accessioned not only easel paintings and sculptures but also applied arts, industrial and handicraft products, and archaeological and anthropological artifacts, as was the practice at the Association. Finally, the diversity of objects was not an aberration but rather evidence of an institution's encyclopedic aspirations and of its prestige. For example, John Pierpont Morgan's first major 
donation to the Metropolitan Museum of Art in New York consisted of two thousand prized Chinese porcelains in 1902. In fact, the Metropolitan Museum's two most significant expansions in the early decades of the twentieth century were the Department of Decorative Arts and the Department of Far Eastern Art in 1907 and in 1915 , respectively. ${ }^{56}$ Not surprisingly then, although it was a minor collection compared with that of the Metropolitan Museum, the Association opened its Department of Laces and Textiles following the donation of laces, shawls and embroideries by a group of Association members and friends in 1921 .

The inventory of donations made to the organization in 1924 was representative of the period. Aside from roughly a dozen books, the Association received one painting of questionable provenance, an embroidered scarf and handkerchief, a crocheted bag, a carved ivory tusk, and ten unspecified engravings. The next larger donation was a bequest in 1926 by Lewis, who bequeathed an extensive collection of Greek and Roman pottery to the Museum. This donation was a considerable and carefully considered gift by one of the Association's most active supporters. These original ceramics not only were of substantial value but also complemented the Association's prized plaster cast collection. Furthermore, the scope of the collection led to the first cataloguing of Association artworks the following year, in $1927 .{ }^{57}$ Finally, the Lewis bequest highlighted the severe facility constraints facing the growing organization. Crocker pointed out that the valuable collection could only be displayed 
selectively due to the lack of gallery space. Returning from a visit to various art and museum organizations in California, Crocker reported to the Exhibition committee on the advantageous facility and funding resources enjoyed by these institutions. She contrasted recent building improvements and additions for the Palace of the Legion of Honor, the San Francisco Art Association, and the California School of Arts and Crafts with the restricted situation at the Association. "Our work would immediately multiply itself," Crocker suggested in reference to the Los Angeles Museum of History, Science and Art and the Otis Art Institute, "had we such space and means at our command." ${ }^{58}$ Crocker's investigation into Californian peer institutions also illuminated that an unrivaled educational prerogative prevailed at the Association. " $[\mathrm{O}]$ ne could not fail to notice," said Crocker, "that notwithstanding this contrast in housing no institution in California carries on at present so full a programme as ours. For instance, a visit from a class of school children is an unusual incident instead of, as with us, literally an almost everyday occurrence." 59

In 1930, the Association board solved the facility question by what was largely a property trade with the Portland School District. In exchange for its property on SW Fifth and Taylor Streets plus $\$ 25,000$, the Association acquired what was then known as the Ladd School block on Southwest Park Street, the location of the Portland Art Museum to this day. A capital campaign raised roughly $\$ 70,000$ to cover the cost of the significant remodel of the school building on the site. This structure housed Association classrooms and offices 
well into the 1960s. Concurrently, trustee Ayer bequeathed $\$ 100,000$ for an additional museum structure on the Association's new city block. The new Museum building was designed by the firm of the late A.E. Doyle, with Pietro Belluschi largely being credited for the creation of a thoroughly modern, open, and well-lit building. The Museum's first wing opened to the public in November 1932; a second, symmetrical wing was constructed just a few years later with funds from a Hirsch family bequest and opened to the public in 1939. This building and which still serves as the Portland Art Museum's main entrance today. ${ }^{60}$

Nevertheless, the onset of the Depression muted celebrations at the Association. Despite, and in some respects, due to the expansion in facility and endowment, the organization could no longer fully fund its educational programs. Given the Association's identity as a civic institution, public funding seemed a logical solution to maintain what were conceived as general education programs. Self-assuredly, PAA president Carey sketched the following plan to respond to the operating expenses in 1931 and in years to come:

It is evident that the institution, which has now reached a point in its history where it can justly be said to rest upon a firm foundation and to have demonstrated its usefulness, can no longer be properly supported without public aid. Assuming that a large part of its operating expense and cost of maintenance can, as in the past, be derived from membership dues and gifts, any additional funds necessary and proper to keep it going should be provided by taxation, and at the same time a more general use of the exhibitions by the public can be encouraged by the very fact that a part of the expense is provided for in that way. ${ }^{61}$ 
The Association trustees considered a bond measure as well as separate appeals to Multnomah County Commissioners and to the State of Oregon for appropriations. However, only in 1932 and in 1933 did Multnomah County grant a $\$ 5,000$ contribution, despite the organization's excellent political connections. The docent program with Portland Public Schools was discontinued in 1933, the same year that the Association renamed its instructional program the Museum Art School. ${ }^{62}$ Facing further financial deterioration, the organization's trustees concluded the year 1934 with the bleak prospect that the "Art School must be given up, the museum staff cut down, and the hours of entrance limited." ${ }^{63}$ Yet the Association's Museum and Art School not only survived, but by the mid-1940s, flourished again, albeit with different priorities than those of the earlier decades. 


\section{Chapter 6: Conclusion}

The preceding chapters have demonstrated the primacy of the educational component of the Portland Art Association's operations during its first decades. Previous studies of the organization as well as of the Portland art scene as a whole have emphasized the lack of recognized art in the early twentieth-century and have largely ignored the Association's educational aspirations. This thesis, in contrast, describes a strong commitment to and a professionalism in art education at PAA. Progressive Era themes and sources were significant drivers of the Association's development during the period under consideration. Most importantly, a set of expectations and values regarding the meaning of art and art education prevailed in the Portland community during the period, subsumed and obscured by existing scholarship on the dichotomy of modern and traditional art. I call attention to aesthetic ideas and practices that did not simply represent unmodern or anti-modern sentiments, even though they would lose their currency by mid-century. Accordingly, my thesis seeks to move beyond the usual binary oppositions of modern versus traditional or avant-garde versus conservative when describing these now-discarded ideas. ${ }^{1}$

The complex response to modernist and avant-garde challenges was embodied in Crocker's qualified support of new art forms. Though providing relief from convention and imitation, new art was no less in danger of disappointing, and even deceiving, its audience. "This novelty," admonished Crocker, "could slide into a less heavy and dry but also less disciplined sort of 
academicism." ${ }^{2}$ While Crocker welcomed modernism's innovation and disregard for convention, avant-garde work also threatened the authentic aesthetic experience, especially if such experience was conceived of as an intensified, even transcendent, self-experience as was the case with Crocker. Modern arts advancing commodification corroded the moral core of aesthetic experiences. In the new market-place of art and art experiences, the aesthetic encounter no longer guaranteed an encounter with an artwork's presumed higher qualities or, to use Walter Benjamin's term, aura. Art had become merely an item of consumption and Kitsch and sensualism reigned. Crocker's ideas on this topic and their implication for art education and museum practice in the early decades of the twentieth century deserve further attention as they shed light on the American reception of modernism in art and on a peculiar American aesthetic tradition that privileged direct experience, empiricism, and the thing-in-itself in art and aesthetic thought. In this scheme, according to the sentiments of the eminent champion of modern art in America, photographer, writer, and gallerist Alfred Stieglitz, "art's meaning could only work its way outward from the maker's moral core."3

My emphasis on progressive or, at least progressively conflicted, motivations at the center of Association operations also departs from the approach taken in general cultural histories of this period. For example, Alan Trachtenberg has described the period as "The Incorporation of America" in his eponymous study. ${ }^{4}$ He purports that hegemonic cultural and economic programs 
by increasingly national elites transformed the organization of American life, dissolved local authorities and identities and concentrated economic and cultural power within the hands of a national oligarchy. Similarly, Warren Sussman argues that the period saw a shift in American culture from coexisting and equal regional vernaculars to a bifurcation between elite highbrow and popular lowbrow culture. "The desire of the promoters of the new high culture to convert audiences into a collection of people reacting individually rather than collectively," writes Sussman, "was increasingly realized by the twentieth century." Paul DiMaggio's work on Boston's various arts and culture organizations, including the Boston Museum of Fine Art, with which several of the early PAA trustees maintained close connections, describes the presence of strong class bias. ${ }^{6}$ Similarly, historian Neil Harris observes that the "logic of cultural institutions - those concerned with instruction, certification, indoctrination, and entertainment - was conservative." ${ }^{7}$ In fact, cultural historian Jackson Lears has condemned the Arts and Crafts as a key antimodernist force in turn-of-the-century America. Lears charges that its precepts of aesthetic education and artisanal activity did no more than atone for a growing sense of loss in a more secular and materially comfortable society. Aesthetic activity and development, suggests Lears, played well with a rising "therapeutic selfabsorption" and "sense of unreality" in American culture. ${ }^{8}$

PAA and the Portland arts community, however, maintained an egalitarian sensibility and aspiration that cannot be construed as supporting the 
elite interests that underlay cultural and philanthropic activities during that time. Processes like those described by the scholars cited above (legitimization by national elites, creation of new hierarchies of taste) certainly affected cultural advocacy in Portland as well; however, the early history of the Portland Art Association suggests a more complex type of interaction among cultural and social forces and motivations. Further investigation of this topic would be fruitful, especially in the form of a broader - in terms of either time or number of institutions - study of the region's art.

The year 1932 represented a significant transitional point for the Association, as PAA's ambitions for art's relevance to the general public and community life grew weaker. There was increasing specialization of the form and meaning of artistic practice and education. For the PAA this meant institutional consolidation around the collection and exhibition of art objects, which was reflected in the renaming of the educational program as the Museum Art School. ${ }^{9}$ Crocker's memoir describes this transitional moment. Remembering the time of her retirement in 1936, Crocker acknowledged having seen a "stop sign" for her continued stewardship of the organization. According to Crocker, the Association and by extension artistic practice in general were developing in a direction that "pointed further and further from the course which had led to this slight culmination of a way of work to which I was deeply attached. ${ }^{10}$ I propose that the "stop sign" originated in the intersection of two of Crocker's main concerns. First, her vision of art's and art education's general appeal, value, and 
utility seemed largely out of step with contemporary art museum practice by mid-century. The notion of service to the general public had always been difficult to reconcile with an insistence on aesthetic standards. With the absorption of professional art education into the universities, moreover, Crocker's ideal museum would lose its most important audience, professional artists in training. After all, serious artists and artisans were the ultimate arbiters of aesthetic standards. In their absence, Crocker feared the Association and its Museum would be at the mercy of popular demands on the one hand and affluent patrons' arbitrary predilections on the other. Second, the increasing number of arts organizations in existence in Portland by the mid-1930s, such as the Oregon Society of Artists, the American Artists Professional League and the Arts and Crafts School, led not only to a diversity of programs but also to specialization in terms of contents and audiences. The Association and its program no longer united all of the community's artistic study and practices.

Crocker's thinking and its discontinuity with mid-century art museum and aesthetic practices deserve further attention. At the same time, a more thorough exploration of Crocker's aesthetic and philosophical ideas, especially within the context of progressive museum and museum education development during the first decades of the twentieth century, should also furnish insights into the sources of contemporary efforts in museum management, diversification of museum audiences and programs, assertion of creative rights, and claims about the critical role of aesthetic education and practice in a wide array of human 
development and community affairs. Furthermore, a comparative study of other provincial art centers, associations, and museums should yield new insights into a relationship between regional sentiments and national and cosmopolitan innovation, which might prove much more dynamic and interactive than onedirectional models of eventual emulation and eventual homogenization.

Finally, energetic advocacy of art and art education persisted at the Association and in the Portland community. Despite Crocker's mid-century premonitions, the PAA continued its educational commitments and, in the wake of the Servicemen's Readjustment Act of 1944 (“GI Bill”), dramatically expanded its adult studio program. Today, the strength of the Association's successor organizations suggests an intriguingly vigorous history and longstanding advocacy for the visual arts and crafts in the Portland community, which has given us an array of successful organizations that enjoy the interest and support of a broad and diverse public. 


\section{Notes}

Chapter 1

${ }^{1}$ J. D. Cleaver, "Introduction to Oregon Art History," in Oregon Painters, ed. Ginny Allen and Jody Klevit (Portland: Oregon Historical Society Press, 1999), 11-18.

${ }^{2}$ Rachael Griffin, "Portland and Its Environs," in Art of the Pacific Northwest: From the 1930s to the Present (Washington, D.C.: Smithsonian, 1974), 5.

${ }^{3}$ Faith Emerson, "Modern Art Hits Stumptown: Sally H. Lewis and Vanguard Exhibitions at the Portland Art Museum, 1911-1924" (master's thesis, University of Oregon, 1997), 8-21. See also, E. Kimbark MacColl, The Shaping of a City (Portland, Oregon: The Georgian Company Press, 1976), 180.

${ }^{4}$ Letter from Thomas Lamb Eliot to Meier and Frank Company, dated July 15, 1910. Portland Art Association, Letterboxes 1895-1936, Anne and James F. Crumpacker Family Library, Portland Art Museum, Portland, Oregon.

${ }^{5}$ Prudence F. Roberts, Heritage in the Making. Greek and Roman Casts from the Portland Art Museum (Portland, Oregon: Oregon Art Institute, 1987). Pioneering Modernism: Anna B. Crocker and Early Exhibitions at the Portland Art Museum (Portland, Oregon: Portland Art Museum, [2002?]); Shaping a Collection. C. E. S. Wood and Portland's Early Art Scene (Portland, Oregon: Portland Art Museum, [1999?]). Richard Christen, "Julia Hoffman and the Arts and Crafts Society of Portland: An Aesthetic Response to Industrialization," Oregon Historical Quarterly 109, no. 4 (October 2008): 510-535. Lawrence Kreisman and Glenn Mason, The Arts and Crafts Movement in the Pacific Northwest (Portland, Oregon: Timber Press. 2007). Allen and Klevit.

${ }^{6}$ Emerson, "Modern Art Hits Stumptown," 76.

${ }^{7}$ Julia A. Sienkewicz, "Uniting the Arts and the Academy. A History of the CAA Annual Conference," in The Eye, the Hand, the Mind: 100 Years of the College Art Association, ed. Susan Ball (Piscataway, New Jersey: Rutgers University Press, 2010), 90.

${ }^{8}$ George W. Stocking, Jr., "On the Limits of "Presentism" and "Historicism" in the Historiography of the Behavioral Sciences," in Race, Culture \& Evolution: Essays in the History of Anthropology, ed. George W. Stocking, Jr. (New York: The Free Press, 1968), 4. 
${ }^{9}$ Anna B. Crocker, It Goes Deeper Than We Think: Reflections about the Role of Art in Education (Portland, Oregon: privately printed, 1946).

${ }^{10}$ Ibid., 2.

${ }^{11}$ Ingrid A. Steffensen-Bruce, Marble Palaces, Temples of Art: Art Museums, Architecture, and American Culture, 1890-1930 (Lewisburg, Pennsylvania: Bucknell University Press, 1998), 11.

${ }^{12}$ Nathaniel Burt, Palaces for the People: A Social History of the American Art Museum (Boston and Toronto: Little, Brown and Company, 1977), 180-230.

${ }^{13}$ Steffensen-Bruce, Marble Palaces, Temples of Art, 121.

${ }^{14}$ Burt, Palaces for the People, 27.

${ }^{15}$ Quoted in Steffensen-Bruce, 132.

${ }^{16}$ Nancy Einreinhofer, The American Art Museum: Elitism and Democracy (London: Leicester University Press, 1997), 52.

${ }^{17}$ Ibid., 102-103.

${ }^{18}$ Donald Soucy, "A History of Art Education Histories," in Framing the Past: Essays on Art Education, ed. Donald Soucy and Mary Ann Stankiewicz (Reston, Virginia: National Art Education Association, 1990) 14.

${ }^{19}$ Crocker, 48.

Chapter 2

${ }^{1}$ Burt, Palaces for the People, 235.

${ }^{2}$ H. Wayne Morgan, New Muses: Art in American Culture, 1865-1920 (Norman, Oklahoma: University of Oklahoma Press, 1978), 48.

${ }^{3}$ Robert Hughes, American Visions. The Epic History of Art in America (New York: Knopf, 1997), 214.

${ }^{4}$ Crocker, It Goes Deeper Than We Think: Reflections about the Role of Art in Education, 5.

${ }^{5}$ Portland Art Association, The Art Scene - 1892-1905 (Oregon Historical Society Records and Photographic Department, Association \& Organizations, PDX Art Museum - Controversy, Box 26, undated photocopy), 1.

${ }^{6}$ Steffensen-Bruce, Marble Palaces, Temples of Art, 121

${ }^{7}$ MacColl, The Shaping of a City, 180. 
${ }^{8}$ Jewel Lansing, Portland: People, Politics, and Power, 1851-2001 (Corvallis, Oregon: Oregon State University Press, 2003), 189, 196, 197.

${ }^{9}$ Paul G. Merriam, "Urban Elite in the Far West Portland, Oregon, 18701890," Journal of the Southwest 18, no. 1 (Spring 1976): 49.

${ }^{10}$ Portland Art Museum. Fiftieth Anniversary Exhibition, 1892-1942 (Portland, Oregon: Portland Art Museum, 1942), 4.

${ }^{11}$ Crocker, It Goes Deeper Than We Think, 5.

${ }^{12}$ Ibid., 4.

${ }^{13}$ Portland Art Association, Articles of Incorporation 1892, Rex Arragon Library, Portland Art Museum, Portland, Oregon.

${ }^{14}$ Quoted in Emerson, "Modern Art Hits Stumptown," 14.

${ }^{15}$ MacColl, The Shaping of a City, 181 and 272. The better known, but equally unrealized, Bennett Plan of 1912 for the development of urban Portland also received critical support from several key PAA trustees, most notably C.F. Swigert. MacColl, 423; the Bennett Plan also called for raising monumental buildings along the North Park Blocks and West Burnside including a museum and theatre, Emerson, "Modern Art Hits Stumptown," 11.

${ }^{16}$ William H. Wilson, The City Beautiful Movement (Baltimore: Johns Hopkins University Press, 1989), 1.

${ }^{17}$ Quoted in Portland Art Association, The Art Scene - 1892-1905, 1.

${ }^{18}$ Emerson, "Modern Art Hits Stumptown,“ 15. Sally Lawrence, A History of Pacific Northwest College of Art (Portland, Oregon, photocopy dated 1998).

${ }^{19}$ Steffensen-Bruce, Marble Palaces, 17.

${ }^{20}$ Quoted in Emerson, "Modern Art Hits Stumptown," 15. See also Roberts, Heritage in the Making. Greek and Roman Casts from the Portland Art Museum. Portland Art Association, Letterboxes 1895-1936, Anne and James F. Crumpacker Family Library, Portland Art Museum, Portland, Oregon.

${ }^{21}$ Portland Art Association, Catalogue of the Corbett Collection of Casts from Greek and Roman Sculpture (Portland, Oregon: F. W. Baltes and Company, 1897), ii.

${ }^{22}$ Alan Wallach, "The American Cast Museum: An Episode in the History of the Institutional Definition of Art," in Exhibiting Contradiction: Essays on the Art Museum in the United States, ed. Alan Wallach (Amherst: University of Massachusetts Press: 1998), 46.

${ }^{23}$ Ibid., 46.

${ }^{24}$ Carl Goldstein, Teaching Art: Academies And Schools From Vasari To Albers (Cambridge, England: Cambridge University Press, 1996), 119-121, 144. 
${ }^{25}$ Ibid., 158.

${ }^{26}$ Mary Ann Stankiewicz, "A Picture Age: Reproductions in Picture Study," in Studies in Art Education 26, no. 2 (Winter, 1985): 86-92.

${ }^{27}$ Crocker, It Goes Deeper Than We Think, 6.

${ }^{28}$ Emerson, "Modern Art Hits Stumptown,“ 20.

${ }^{29}$ Cleaver. "Introduction to Oregon Art History," 153.

${ }^{30}$ Arthur D. Efland, A History of Art Education. Intellectual and Social

Currents in Teaching the Visual Arts (New York and London: Teachers College Press, Columbia University, 1990), 145-146. Stankiewicz, "A Picture Age," 90-91.

${ }^{31}$ Frank Weitenkampf, “The Museum and the Small Library," Art and Progress 4, (November 1912-October 1913), 1070.

${ }^{32}$ Quoted in Karl E. Meyer, The Art Museum: Power, Money, Ethics (New York: Morrow, 1979), 39.

${ }^{33}$ Letter from December 1, 1898, by J.C. Dana, Librarian, The City Library Association, Springfield, Massachusetts, to Portland Art Association.

${ }^{34}$ Quoted in Florence N. Levy, "Educational Work of Art Museums," in Art Education in the Public Schools of the United States, ed. James Parton Haney (New York: American Art Annual, 1908), 409.

${ }^{35}$ Roberts, "Heritage in the Making," n.p.

${ }^{36}$ The Fine Arts Museums of San Francisco. Selected Works (San Francisco: The Fine Arts Museums of San Francisco, 1987), 9-11. Seattle Art Museum, "History," http://www .seattleartmuseum.org/AboutUs/History/History.asp (accessed December 12, 2009).

${ }^{37}$ Grove Art Online. "USA, §XIV: Museums,” Oxford Art Online, http://0www.oxfordartonline.com.catalog.multcolib.org/subscriber/article/grove/art/T087095 $\operatorname{pg} 14 ? \mathrm{q}=$ usa + museums\&search=quick $\&$ pos $=1 \& \_$start $=1 \#$ firsthit $($ accessed June 15, 2009).

${ }^{38}$ The Toledo Museum of Art, "About," http://www.toledomuseum.org/about/history (accessed January 5, 2010).

${ }^{39}$ Joshua C.Taylor, The Fine Arts in America (Chicago: University of Chicago Press, 1979), 95.

${ }^{40}$ Stankiewicz, “'The Eye Is a Nobler Organ': Ruskin and American Art Education," Journal of Aesthetic Education 18, no. 2 (Summer, 1984): 51.

${ }^{41}$ Hughes, American Visions, 215.

${ }^{42}$ Roger B. Stein, John Ruskin and Aesthetic Thought in America, 1840-1900 (Cambridge, Massachusetts: Harvard University Press, 1967), 224-242. 
${ }^{43}$ Taylor, The Fine Arts in America, 115.

${ }^{44}$ Stein, John Ruskin and Aesthetic Thought in America, 1840-1900, 259.

${ }^{45}$ Ibid., 147-151.

${ }^{46}$ Wilson, The City Beautiful Movement, 79.

${ }^{47}$ Stein, John Ruskin and Aesthetic Thought in America, 1840-1900, 259.

${ }^{48}$ John Dewey, Art as Experience (1934; repr., New York: Penguin, 2005), $12-$ 19,81 .

${ }^{49}$ Portland Art Association, "Twenty-Fourth Annual Report" (Portland Art Association, 1916), 18.

Chapter 3

${ }^{1}$ Roberts, Shaping a Collection, n.p. Christen, "Julia Hoffman and the Arts and Crafts Society of Portland," 529.

${ }^{2}$ Edwin Bingham and Tim Barnes, eds. Wood Works: The Life and Writings of Charles Erskine Scott Wood (Corvallis, Oregon: Oregon State University Press, 1997). Roberts, Shaping a Collection. , n.p.

${ }^{3}$ Roberts, Shaping a Collection.

${ }^{4}$ Ibid., n.p.

${ }^{5}$ Ibid., n.p.

${ }^{6}$ Robert L. Joki, "The Art of The Fair. The Lewis and Clark Centennial Exposition, 1905," in Allen and Klevit, eds., Oregon Painters, 33.

${ }^{7}$ Steffensen-Bruce, Marble Palaces, Temples of Art, 11, 48.

${ }^{8}$ Ibid., 74.

${ }^{9}$ Ibid., 67.

${ }^{10}$ Ibid., 231.

${ }^{11}$ James Parton Haney, "The Development of Art Education in the Public Schools," in Art Education in the Public Schools of the United States, ed. James Parton Haney (New York: American Art Annual, 1908), 53.

${ }^{12}$ Lansing, Portland: People, Politics, and Power, 1851-2001, 249, 256.

${ }^{13}$ Emerson, "Modern Art Hits Stumptown,"18, 20.

${ }^{14}$ Steffensen-Bruce, Marble Palaces, Temples of Art, 121. 
${ }^{15}$ Karl Meyer, The Art Museum: Power, Money, Ethics (New York: Morrow, 1979), 38.

${ }^{16}$ Allen and Klevit, eds., Oregon Painters, 18, 36, 110.

${ }^{17}$ Raymond J. Steiner, The Arts Students League of New York: A History (Saugerties, New York: CSS Publications, 1999), 96.

${ }^{18}$ Ibid., 34.

${ }^{19}$ Emerson, "Modern Art Hits Stumptown," 19.

${ }^{20}$ Ibid., 18-20.

${ }^{21}$ Joki, "The Art of The Fair," 34.

${ }^{22}$ Crocker, It Goes Deeper Than We Think, 8.

${ }^{23}$ According to Crocker these classes included drawing from the plaster casts, a practice DuMond was the first to abolish at a later point at the New York Student Art League. Ibid., 8; Steiner, The Arts Students League of New York, 96.

${ }^{24}$ When early in 1905, Henrietta Failing, the Association's curator, approached DuMond about the inclusion of finely crafted objects in the Exposition art exhibit, he categorically denied the request, insisting on a strict separation of the fine arts and the applied crafts: "Applied Arts cases down through the center of a $25 \mathrm{ft}$. gallery ruins the effect of everything." Quoted in Kreisman and Mason, The Arts and Crafts Movement in the Pacific Northwest, 67.

${ }^{25}$ Quoted in Richard Christen, "Julia Hoffman and the Arts and Crafts Society of Portland: An Aesthetic Response to Industrialization" in Oregon Historical Quarterly 109, no. 4 (October 2008): 518.

${ }^{26}$ Wendy Kaplan, "The Lamp of British Precedent: An Introduction to the Arts and Crafts Movement," in Kaplan, ed., "The Art That Is Life": The Arts \& Crafts Movement in America 1875-1920 (Boston: Museum of Fine Arts, 1987), 52.

${ }^{27}$ Quoted in Nikolaus Pevsner, Pioneers of Modern Design. From William Morris to Walter Gropius (1936; repr., New Haven, Massachusetts: Yale University Press, 2004), 15.

${ }^{28}$ For a prominent example of its use, the neologism was the subtitle for William Price's journal The Artsman (Philadelphia: Rose Valley Press), 1903-1907; Robert Edwards, "The Art of Work," in Kaplan, ed., "The Art That is Life, 235.

${ }^{29}$ Eileen Boris, Art and Labor: Ruskin, Morris, and the Craftsman Ideal in America (Philadelphia: Temple University Press, 1986), 32.

${ }^{30}$ Kaplan, “The Lamp of British Precedent," 60.

${ }^{31}$ Edwards, "The Art of Work," 234. 
${ }^{32}$ Letter dated December 27, 1895, Portland Art Association, Letterboxes 1895-1936.

${ }^{33}$ When Hoffman died in a car accident in 1934, Crocker and her sister Florence designed and created a tapestry that was installed at Hoffman's memorial service in Portland's First Unitarian Church and remained there until a fire destroyed much of the church in 1969. Quoted in Museum of Contemporary Craft, http://www.museumofcontemporarycraft.org/exhibitions/feature/1769 (accessed February 10, 2011).

${ }^{34}$ Lisa Dickinson Michaux, “A Forgotten Collector Makes His Mark: William Mead Ladd and Print Collecting at the Turn of the Century," in Twenty-First-Century Perspectives on Nineteenth-Century Art: Essays in Honor of Gabriel P. Weisberg, eds. Petra Ten-Doesschate Chu and Laurinda S. Dixon (Newark, Delaware: University of Delaware Press, 2008): 85.

${ }^{35}$ Roberts, Shaping a Collection, n.p.

${ }^{36}$ Letter dated November 13, 1911, from Thomas Lamb Eliot to Henrietta. H. Failing, Portland Art Association, Letterboxes 1895-1936.

Chapter 4

${ }^{1}$ Portland Art Association, Eighteenth Annual Report, 1910, 9.

${ }^{2}$ For professionalization of museum practice and education, see Philip D. Spiess, "Toward a New Professionalism: American Museums in the 1920s and 1930s," Museum News 75, no. 2 (1996.): 39-41. Crocker, for example, was especially active in the Western Association of Art Museum Directors; she also relied on publications and travelling exhibits initiated by the American Federation of Arts, which by 1915 had established more than two hundred chapters nationally. For expansion and standardization of art teacher training and education, see Foster Wygant, School Art in American Culture 1820-1970 (Cincinnati, Ohio: Interwood, 1993), 22-26. While less significant regarding the PAA, the founding of the College Art Association in 1911 deserves mentioning in this context, see Susan Ball, The Eye, the Hand, the Mind: 100 Years of the College Art Association (Piscataway, New Jersey: Rutgers University Press, 2010).

${ }^{3}$ The Portland Art Association, Record Group II, Series I.

${ }^{4}$ Crocker, It Goes Deeper Than We Think, 8. Cleaver, "Introduction to Oregon Art History," in Allen and Klevit, eds., Oregon Painters, 17-18. Kreisman and Mason, The Arts and Crafts Movement in the Pacific Northwest, 71. For turn-of-the-century artist education, see Morgan, New Muses: Art in American Culture, 1865-1920, especially chapter 3, "Studying Art at Home and Abroad," 77-111. 
${ }^{5}$ Howard Singerman explores the bifurcation of art education in the early twentieth century between artist teacher (usually male and foundational) and art teacher (usually female and parochial) and its profound implications on the development of the field and institutionalization of aesthetic education in America, Art Subjects (Berkeley: University of California Press, 1999), 56-60.

${ }^{6}$ Hoffman's patronage and service are documented in the Portland Art Association's Annual Reports 1910-1934; Christen discusses the founding of the school of the Arts and Crafts Society in 1934, 529. Annual course catalogs of the Art School use the terms "handwork," "handiwork," and "design" interchangeably, see for example 1928/1929, 5-6.

${ }^{7}$ Efland, A History of Art Education, 165-166. Foster Wygant, School Art in American Culture 1820-1970 (Cincinnati, Ohio: Interwood, 1993), 33-34, 57; Nov 7 , 1911, Thomas L Eliot, on The Reed Institute letterhead to C. F. Swigert, Portland Art Association, Letterboxes 1895-1936.

${ }^{8}$ Crocker, It Goes Deeper Than We Think, 4.

${ }^{9}$ This author has speculated about a meeting between Crocker and Simmons in New York during the summer of 1909. PAA trustees obviously knew Crocker and, following the acceptance of her appointment as curator, could have asked her to interview potential candidates from Columbia University Teacher College. Crocker, however, does not mention an encounter with Simmons and I did not find other documentation confirming such a meeting.

${ }^{10}$ Emerson, "Modern Art Hits Stumptown,“ 23.

${ }^{11}$ Crocker's memoir recounts the circumstances of her hiring, It Goes Deeper Than We Think, 4-12. Because of her more than quarter-century long service at the helm of the PAA, Crocker's hiring had a profound effect on the development of the Art School and the PAA beyond the end of her tenure in 1936.

${ }^{12}$ Portland Art Association Bulletin \#1, Portland Art Association, Annual Bulletins 1909-1936.

${ }^{13}$ Portland Art Association, Eighteenth Annual Report, 1910, 15.

${ }^{14}$ Crocker, It Goes Deeper Than We Think, 30.

${ }^{15}$ Portland Art Museum, Fiftieth Anniversary Exhibition 1892-1942 (Portland, Oregon: Portland Art Museum, 1942), 6.

${ }^{16}$ Florence N. Levy, "Educational Work of Art Museums," Art Education in the Public Schools of the United States, ed. James Parton Haney (New York: American Art Annual, 1908), 409.

${ }^{17}$ http://www.toledomuseum.org/about/history accessed Jan. 6, 2010. PAA 1931,7 . The PAA would offer free children's courses in response to the Great Depression and in support of its school teacher education program in 1930, PAA Annual Report 1931, 7. 
${ }^{18}$ Spiess, "Toward a New Professionalism," 39-40. Portland Art Association, Twenty-third Annual Report, 1915, 6.

${ }^{19}$ Portland Art Association, Twenty-second Annual Report, 1914, 17.

${ }^{20}$ Portland Art Association, Annual Report, 1920, 4.

${ }^{21}$ Efland, A History of Art Education, 146.

${ }^{22}$ Quoted in Singerman, Art Subjects, 57. Singerman furthermore observes that Bailey conflates such feminization of the art classroom with the figure of the teacher. Bailey demanded that for the teacher, "cleanliness, neatness, a becoming coiffure, a simple costume appropriate to her profession and in right relation to her figure and complexion are absolutely essential. No principle of composition of line, no theory of harmonious coloring should be violated in herself." Quoted in ibid., 57.

${ }^{23}$ Stankiewicz, “The Eye Is a Nobler Organ”: Ruskin and American Art Education," in Journal of Aesthetic Education 18, no. 2 (Summer, 1984), 61.

${ }^{24}$ Portland Art Association, Twenty-fifth Annual Report, 1917, 9. The painting was by Norwegian-born American painter Jonas Lie, who was best known for his impressionistic paintings of natural or pastoral scenes. The work was purchased out of an exhibit at the Association's Museum in March 1917; it was the only piece sold out of the thirty-seven paintings in the exhibit.

${ }^{25}$ Portland Art Association, Twenty-second Annual Report, 1914, 6.

${ }^{26}$ Stankiewicz, “A Picture Age: Reproductions in Picture Study,” 86-92. Portland Art Association, Eighteenth Annual Report, 1910, 8.

${ }^{27}$ Portland Art Association, Twenty-third Annual Report, 1915, 12.

${ }^{28}$ Portland Art Association, Twenty-fifth Annual Report, 1917, 14. Stankiewicz, "A Picture Age," 86. Peter Smith, The History of American Art Education: Learning about Art in American Schools (Westport, Conn.: Greenwood, 1996), 79.

${ }^{29}$ Portland Art Association, Twenty-third Annual Report, 1915, 10: “The Curator spoke to the Parents' Educational Bureau on "The Artistic Training and Development of Young Children."

${ }^{30}$ Portland Art Association, Twenty-fifth Annual Report, 1917, 15. Portland Art Association, Twenty-second Annual Report, 1914, 9.

${ }^{31}$ Prudence Roberts Heritage in the Making, n.p.

${ }^{32}$ Portland Art Association, Twenty-first Annual Report, 1913, 13.

${ }^{33}$ Ibid., 12.

${ }^{34}$ In fact, the organizations that have succeeded the Art School more or less directly, namely the Northwest Film Center, the Oregon College of Art and Craft and 
Pacific Northwest College of Art enrolled primarily local students, at least to the close of the century.

${ }^{35}$ Quoted in Portland Art Association, Twenty-third Annual Report, 1915, 6.

${ }^{36}$ Portland Art Association, Nineteenth Annual Report 1911, 13. For The Eight, see Morgan, New Muses, 178-179, and Emerson, "Modern Art Hits Stumptown,“ 28-32.

${ }^{37}$ Emerson, "Modern Art Hits Stumptown,"24; regarding Brancusi’s Muse, see ibid., 63-68; Emerson also mentions that Brancusi had a plaster cast of the Muse exhibited in the Armory Show, ibid., 65.

${ }^{38}$ Portland Art Association, Twentieth Annual Report 1912, 9, 16.

${ }^{39}$ Emerson, "Modern Art Hits Stumptown,"18; for example, Torrey lectured on "The Significance of Certain Tendencies in Modern Art" at the Museum in April 1914, Portland Art Association, Twenty-second Annual Report, 1914

${ }^{40}$ Portland Art Association Bulleting \#1, Portland Art Association, Annual Bulletins 1909-1936.

${ }^{41}$ Portland Art Association, Eighteenth Annual Report, 1910, 14.

${ }^{42}$ Portland Art Association, Twentieth Annual Report, 1912, 14-15.

${ }^{43}$ Portland Art Association, Twenty-fifth Annual Report, 1917, 14. Efland, A History of Art Education, 174, Portland Art Association, Twentieth Annual Report, 1912, 12-13.

${ }^{44}$ Portland Art Association, Eighteenth Annual Report, 1910, 10: "This year is also marked by important and far-reaching changes in the organization of the Association itself. The result of the appointment of standing committees as provided in the by-laws adopted at the special meeting in December is that a larger number of members are engaged in advancing the work of the Association."

${ }^{45}$ Quoted in Portland Art Association, Twenty-fifth Annual Report, 1917, 5.

${ }^{46}$ Portland Art Association, Twenty-first Annual Report, 1913, 6.

${ }^{47}$ Joshua Taylor, "Introduction," in Art of the Pacific Northwest: From the 1930s to the Present, (Washington, D. C.: Smithsonian Institution, 1974), XII. The Art School's short-lived publication, The Oregon Artist 1, no. 1 (spring 1952), lists Taylor as a student in1935-36. An entry in Duke University's Library confirms his attendance of Art School classes prior to graduating from Reed College with a bachelor's degree in 1939 and a master's degree in literature after his return from service in World War II (http://www.lib.duke.edu/lilly/artlibry/dah/taylorj.htm, accessed November 14, 2005).

${ }^{48}$ Joyce Woelfle Lehman, "Art Museum Schools: The Rise and Decline of a New Institution in Nineteenth-Century America," in The Cultivation of Artists in 
Nineteenth-Century America, eds. Georgia Brady Barnhill, Diana Korzenik, and Caroline F. Sloat (Worcester, Massachusetts: American Antiquarian Society, 1997), 207. Furthermore, Lehman's description of the studio program at the Buffalo Academy in New York very much fits the PAA: "Although some women at that school and elsewhere may have been elite dilettantes, it seems evident that many of them were serious students. Art training was needed by women expecting to teach in public schools, by participants in the arts and crafts movement, and by those involved in cottage industries" Lehman, 213.

${ }^{49}$ Portland Art Association, Twenty-third Annual Report, 1915, 5.

Chapter 5

${ }^{1}$ Crocker, It Goes Deeper Than We Think, 42.

${ }^{2}$ Quoted in Portland Art Association, Twentieth Annual Report, 1912, 10; Portland Art Association, Twenty-third Annual Report, 1915, 10.

${ }^{3}$ June 2, 1917 Crocker to Reed College President William T. Foster, Portland Art Association, Letterboxes 1895-1936. Portland Art Association, Twenty-fourth Annual Report, 1916-17, 10. Without providing a deeper analysis of student demographics during the Art School's first two decades, Association Reports imply a shift toward the enrollment of younger adults and recent high school graduates during the period. The introduction and popularity of competitive scholarships for graduates of Oregon high schools as well as surviving correspondences by Crocker and parents of young adult students interested in Art School attendance reflected this shift. Portland Art Association, Twenty-first Annual Report, 1913, 14; Portland Art Museum, Record Group II, Series 1.

${ }^{4}$ Wygant, School Art in American Culture 1820-1970, 23-24.

${ }^{5}$ Philip Niles, Beauty of the City: A.E. Doyle, Portland's Architect (Corvallis: Oregon State University Press, 2008), 66.

${ }^{6}$ Letter dated June 2, 1917, from Crocker to Reed College President William T. Foster, Portland Art Association, Letterboxes 1895-1936.

${ }^{7}$ Niles, Beauty of the City, 85.

${ }^{8}$ Christensen, "Julia Hoffman and the Arts and Crafts Society of Portland," 522.

(http://www.oregonencyclopedia.org/entry/view/pittock_mansion/ accessed May 15, 2010). Allen and Klevit, Oregon Painters, 312-313. 
${ }^{9}$ Allen and Klevit, Oregon Painters, 207, 290.

${ }^{10}$ Crocker and Wentz also were a major part of the first vacation community in Neahkahnie, known today as the town of Manzanita on the Oregon coast. In fact, they both owned summer homes designed by Portland architect Albert E. Doyle, who also built his own cottage as well as homes for Association trustee Eliot and long-serving Portland Library Director Mary Frances Isom in the same area, creating a seasonal "community of well-educated, artistic individuals with similar interests, attitudes, and influences." Jane Comerford, At the Foot of the Mountain, (Portland, Oregon: Dragonfly Press, 2004), 75.

${ }^{11}$ Portland Art Commission. In Praise of Anna B. Crocker and Harry F. Wentz (1959), n.p. Niles, Beauty of the City, 181.

${ }^{12}$ Portland Art Association, Twenty-third Annual Report, 1915, 11.

${ }^{13}$ Michael Munk, “The Diaries of Helen Lawrence Walters," Oregon Historical Quarterly 106, no. 4 (Winter 2005): 3, 7.

${ }^{14}$ Crocker summed up the curatorial program through the early 1930s: "Temporary exhibitions - more important circulating shows and the works of local architects, craftsmen, sculptors and painters, with annual art school and Christmas exhibitions and flower festivals -were still our mainstay." It Goes Deeper Than We Think, 25. Portland Art Association, Twenty-third Annual Report, 1913, 7. Emerson, "Modern Art Hits Stumptown,“ 37, 59.

${ }^{15}$ Roberts, Shaping a Collection.

${ }^{16}$ Crocker, It Goes Deeper Than We Think, 21 and 22.

${ }^{17}$ Ibid., 21.

18 Ibid.

${ }^{19}$ Portland Art Association, Twenty-sixth Annual Report, 1928, 13.

${ }^{20}$ Crocker, It Goes Deeper Than We Think, 20.

${ }^{21}$ Gary Kemp, “The Croce-Collingwood Theory as Theory," The Journal of Aesthetics and Art Criticism 61, no. 2 (Spring 2003): 171. George H. Douglas, "A Reconsideration of the Dewey-Croce Exchange," The Journal of Aesthetics and Art Criticism 28, no. 4 (Summer 1970): 503.

${ }^{22}$ Crocker, It Goes Deeper Than We Think, 76-80.

${ }^{23}$ Marilee Boyd Meyer, "Arthur Wesley Dow and his Influence on the Arts and Crafts," in Arthur Wesley Dow, 1857-1922: His Art and His Influence, ed. Nancy E. Green (New York: Spanierman Gallery, 1999), 48. The work of three American educators, Denman Waldo Ross, Ernest Batchelder, and Arthur Wesley Dow, articulated a universality of design principles, applicable to all artistic processes. This new body of art education had little concern for identifying and enforcing distinctions 
between decorative and fine arts. It also articulated a formalist aesthetic agenda, which is usually associated with the critical writings of Roger Fry and Clive Bell and the mid-century transformation of American art education in the wake of the Bauhaus immigration. Portland Art Association, Twenty-fifth Annual Report, 1917, 6.

${ }^{24}$ Edward. S. Cooke, "Talking or Working: The Conundrum of Moral Aesthetics in Boston's Arts and Crafts Movement," in Inspiring Reform, ed. Marilee Boyd Meyer (New York: Harry N. Abrams, 1997): 28. Efland, A History of Art Education, 177-179. Wygant, School Art in American Culture 1820-1970, 26-28.

${ }^{25}$ Arthur Wesley Dow, "Modernism in Art," The American Magazine of Art (January 1917): 114.

${ }^{26}$ Portland Art Association, Annual Report, 1917-1919, 6. Arthur Wesley Dow, "The Use of Pictures in Art Teaching," in the School Arts Book, ed. Henry Turner Bailey (Boston, The Applied Arts Guild, 1908), 496.

${ }^{27}$ Portland Art Association, Annual Report, 1917-1919, 6; 8-1-1917 Crocker to Failing; 6-11-1917, Crocker to L. A Lewis; 7-9-1917 letter Crocker to Marian Hendrie. Finally, Dow's criticism of rigid art doctrines and conservative academies appealed to art educators and reinforced the centrality of the arts in general education: Dow had set this agenda out assertively in his landmark art education manual Composition: "Hence the effort to find art-structure resolves itself into a development of appreciation. This faculty is a common human possession but may remain inactive. A way must be found to lay hold upon it and cause it to grow. A natural method is that of exercises in progressive order, first building up very simple harmonies, then proceeding on to the highest forms of composition. Such a method of study includes all kinds of drawing, design and painting." In Dow, Composition: A Series of Exercises in Art Structure for the Use of Students and Teachers (Garden City, New York: Doubleday, 1918), 3.

${ }^{28}$ Letter dated May 20, 1918 in Portland Art Association, Record Group II, Series 1, Box 11, 1917-18.

${ }^{29}$ Ibid.

${ }^{30}$ Portland Art Association, Annual Report, 1917-1919, 5.

${ }^{31}$ Portland Art Association, Annual Report, 1923, 8.

${ }^{32}$ Portland Art Association, Annual Report, reports, 1910-1934.

${ }^{33}$ Efland, A History of Art Education, 195.

${ }^{34}$ Portland Art Association, Annual Report, 1927, 10.

${ }^{35}$ Portland Art Association, Annual Report, 1928, 9-10.

${ }^{36}$ Portland Art Association, Annual Report, 1927, 9. 
${ }^{37}$ Portland Art Association, Annual Report, 1928, 6.

${ }^{38}$ Letter dated April 27, 1925, Portland Art Association, Letterboxes.

${ }^{39}$ Letter dated June 24, 1925, Portland Art Association, Letterboxes. Though rarely used over the past two decades, an agreement is still in place that permits students of Reed College and Pacific Northwest College of Art enrollment in courses at the partner college without incurring additional expenses or having to meet further admission requirements.

${ }^{40}$ Portland Art Association, Annual Report, 1928, 5.

${ }^{41}$ Emerson, "Modern Art Hits Stumptown," 59.

${ }^{42}$ Sally Lewis bequeathed Muse to the Portland Art Museum in 1959. She had already gifted her extensive collection of Greek and Roman pottery, all originals, not plaster copies, in 1926. Portland Art Association, Annual Report, 1927, 4-6.

${ }^{43}$ Quoted (April 3, 1924) in Emerson, "Modern Art Hits Stumptown," 68.

${ }^{44}$ Letter from Lewis to Crocker March 1924; also, letter from Ruth Cowgill, librarian at the Carnegie Public Library in Boise, to Crocker, Record Group II, Series 1, 1924.

${ }^{45}$ Crocker, It Goes Deeper Than We Think, 23.

${ }^{46}$ Portland Art Association, 1926, Letterbox 23. Multiple copies. The Society of Friends immediately proceeded with a first purchase the following year, 1927, though this would not be a contemporary artwork, but instead permanently secured a seventeenth-century painting by Dutch artist Willem Kalf, which had been already been on loan to the Association for a considerably time.

${ }^{47}$ Portland Art Association, 1926, Letterbox 23.

${ }^{48}$ Crocker, It Goes Deeper Than We Think, 24.

${ }^{49}$ Roger Hull, “Region, Expression, and 'Oregon Art' - 1930-1970” in Oregon Experience: The Art Makers (Oregon Public Broadcasting, http://www.opb.org/programs/oregonexperiencearchive/artmakers/essay.php, accessed February 26, 2009).

${ }^{50}$ Taylor, "Introduction," in Art of the Pacific Northwest, XI.

${ }^{51}$ Ibid., XII.

${ }^{52}$ Crocker, It Goes Deeper Than We Think, 5, 24-25.

${ }^{53}$ Ibid., 23.

${ }^{54}$ Portland Art Association, Annual Report, 1932, 7.

${ }^{55}$ Crocker, though, defended the early trustees as well as her own policy toward accessioning work and pointed out that "gifts without worth" had been 
refused. 25. The Lewis collection was not only a source for exhibits at the Museum, but also a destination for Dow, who himself was an expert on Japanese art and had built central aspects of his aesthetic and education theory on Japanese traditions. Portland Art Association, letter dated June 11, 1917, Crocker to L. A Lewis.

${ }^{56}$ Einreinhofer, The American Art Museum, 43-46.

${ }^{57}$ Portland Art Association, Annual Report, 1922, 4-6; 1925, 8; 1926, 4; PAA, 1928, 13.

${ }^{58}$ Quoted in Portland Art Association, Letterbox 1926.

${ }^{59}$ Portland Art Association, Annual Report, 1927, 4. Portland Art Association, Letterbox 1926.

${ }^{60}$ Portland Art Association, Annual Report 1930, 6-7. Portland Art Museum. Fiftieth Anniversary Exhibition, 1892-1942, 7-8. Portland Art Association, Annual Report 1932, 8.

${ }^{61}$ Quoted in Portland Art Association, Annual Report, 1931, 7.

${ }^{62}$ Portland Art Association, Annual Report, 1934, 10.

${ }^{63}$ Portland Art Association, Annual Report, 1935, 3.

Chapter 6

${ }^{1}$ Rachael Griffin, "Portland and Its Environs," in Art of the Pacific Northwest: From the 1930s to the Present (Washington, D.C.: Smithsonian, 1974), 3-4. Cleaver, "Introduction to Oregon Art History," 8-11.

${ }^{2}$ Crocker, It Goes Deeper Than We Think, 20.

${ }^{3}$ Hughes, American Visions, 350.

${ }^{4}$ Alan Trachtenberg, The Incorporation of America. Culture And Society in the Gilded Age (New York: Hill and Wang, 1982).

${ }^{5}$ Warren Sussman, Culture As History: The Transformation of American Society in the Twentieth Century (New York: Pantheon Books, 1984), 195.

${ }^{6}$ Paul DiMaggio, "Cultural Entrepreneurship in Nineteenth-Century Boston: The Creation of an Organizational Base for High Culture in America," Media, Culture \& Society 4, no.1 (January 1982): 33-50. 
${ }^{7}$ Neil Harris, Cultural Excursions: Marketing Appetites and Cultural Tastes in Modern America (Chicago: The University of Chicago Press, 1990), 104.

${ }^{8}$ T. J. Jackson Lears, No Place of Grace: Antimodernism and the Transformation of American Culture, 1880-1920 (New York: Pantheon Books, 1981), 304.

${ }^{9}$ Portland Art Association, Annual Report, 1934, 10.

${ }^{10}$ Crocker, It Goes Deeper Than We Think, 27-28. 


\section{Sources Consulted}

\section{Archives}

Portland Art Association, Annual Bulletins 1909-1936, Registrar, Pacific Northwest College of Art, Portland, Oregon.

—- Annual Reports 1910-1936, Anne and James F. Crumpacker Family Library, Portland Art Museum, Portland, Oregon.

— - Articles of Incorporation 1892, Anne and James F. Crumpacker Family Library, Portland Art Museum, Portland, Oregon.

— Scrapbooks 1908-1930, Anne and James F. Crumpacker Family Library, Portland Art Museum, Portland, Oregon.

— Letterboxes 1895-1936, Anne and James F. Crumpacker Family Library, Portland Art Museum, Portland, Oregon.

Oregon Historical Society Records and Photographic Department, Portland, Oregon.

\section{Brochures and Web Pages}

Guenther, Bruce. "Oral History Interview with Rachael Griffin, February 19-20, 1983." In Archives of American Art, Smithsonian.

http://www.aaa.si.edu/collections/interviews/oral-history-interview-rachaelgriffin-13091 (accessed January 30, 2009).

Oxford Art Online. "USA, §XIV: Museums.” In Grove Art Online. Oxford Art Online, http://0-

www .oxfordartonline.com.catalog.multcolib.org/subscriber/article/grove/art/T $087095 \mathrm{pg} 14$ ?q=usa+museums\&search=quick\&pos=1\&_start=1\#firsthit (accessed June 15, 2009).

Pacific Northwest College of Art. "Institutional History." Pacific Northwest College of Art. http://pnca.edu/about/president/history.php (accessed August 20, 2008).

Portland Art Association. The Oregon Artist 1, no. 1 (Spring 1952).

- Catalogue of the Corbett Collection of Casts from Greek and Roman Sculpture. Portland, Oregon: F. W. Baltes and Company, 1897.

Portland Art Commission. In Praise of Anna B. Crocker and Harry F. Wentz. Portland, Oregon: Abbott, Kerns and Bell Co., 1959.

Portland Art Museum. Fiftieth Anniversary Exhibition, 1892-1942. Portland, Oregon: Portland Art Museum, 1942. 
—_. "Museum History." Portland Art Museum. http://web.pam.org/asp/about_us/museum_history.asp\#1910 (accessed February 8, 2004).

Roberts, Prudence F. Heritage in the Making. Greek and Roman Casts from the Portland Art Museum. Portland, Oregon: Oregon Art Institute, 1987.

- Pioneering Modernism: Anna B. Crocker and Early Exhibitions at the Portland Art Museum. Portland, Oregon: Portland Art Museum, [2002?].

—. Shaping a Collection. C. E. S. Wood and Portland's Early Art Scene. Portland, Oregon: Portland Art Museum, [1999?].

Seattle Art Museum. "History." Seattle Art Museum. http://www.seattleartmuseum.org/AboutUs/History/History.asp (accessed December 12, 2009).

The Fine Arts Museums of San Francisco. Selected Works. San Francisco: The Fine Arts Museums of San Francisco, 1987.

The Toledo Museum of Art. "About." The Toledo Museum of Art. http://www.toledomuseum.org/about/history (accessed January 5, 2010).

\section{Manuscripts}

Berman, Daniel. “Harry Wentz, 1875-1965.” Portland, Oregon: photocopy dated 1991.

Crocker, Anna B. It Goes Deeper Than We Think: Reflections about the Role of Art in Education. Portland, Oregon: privately printed, 1946.

“In memoriam, Julia E. Hoffman, 1856-1934.” Portland, Oregon: n.a., copy dated 1945.

Lawrence, Sally. “A History of Pacific Northwest College of Art.” Portland, Oregon, photocopy dated 1998.

Peirce, Bob. "The Post-War Years at the Museum Art School.“ Portland, Oregon, undated photocopy.

Portland Art Association. “The Art Scene - 1892-1905.” Oregon Historical Society Records and Photographic Department, Association \& Organizations, PDX Art Museum - Controversy, Box 26, undated photocopy.

\section{Published Sources}

Abbott, Carl. The Great Extravaganza: Portland and the Lewis and Clark Exposition. Portland: Oregon Historical Society Press, 2004.

Allen, Ginny and Jody Klevit, eds. Oregon Painters. Portland: Oregon Historical Society Press, 1999. 
Amburgy, Patricia M., ed. The History of Art Education: Proceedings from the Second Penn State Conference, 1989. Reston, Virginia: National Art Education Association, 1992.

Ball, Susan. "The Beginnings. "Art for Higher Education, and Higher Education for Artists." In The Eye, the Hand, the Mind: 100 Years of the College Art Association, edited by Susan Ball, 19-32. Piscataway, New Jersey: Rutgers University Press, 2010.

Bailey, H. T., ed. The School Arts Book. Boston, Massachusetts: The Applied Arts Guild, 1908.

Bingham, Edwin and Tim Barnes, eds.. Wood Works: The Life and Writings of Charles Erskine Scott Wood. Corvallis: Oregon State University Press, 1997.

Blair, Karen. The Torchbearers: Women and Their Amateur Arts Associations in America, 1890-1930. Bloomington, Indiana: Indiana University Press, 1994.

Borris, Eileen. Art and Labor: Ruskin, Morris, and the Craftsman Ideal in America. Philadelphia: Temple University Press, 1986.

. "Dreams of Brotherhood and Beauty:" The Social Ideas of the Arts and Crafts Movement." In "The Art That is Life": The Arts \& Crafts Movement in America 1875-1920 edited by Wendy Kaplan, 208-222. Boston: Museum of Fine Arts, 1987.

Brooklyn Museum. The American Renaissance, 1876-1917. Brooklyn, New York: Brooklyn Museum, 1979.

Burns, Sarah. Inventing the Modern Artist. Art and Culture in Gilded Age America. New Haven and London: Yale University Press, 1996.

Burt, Nathaniel. Palaces for the People: A Social History of the American Art Museum. Boston and Toronto: Little, Brown and Company, 1977.

Christen, Richard. "Julia Hoffman and the Arts and Crafts Society of Portland: An Aesthetic Response to Industrialization.” Oregon Historical Quarterly 109, no. 4 (October 2008): 510-535.

Cleaver, J. D. "Introduction to Oregon Art History." In Oregon Painters, edited by Ginny Allen and Jody Klevit, 1-26. Portland: Oregon Historical Society Press, 1999.

Conn, Steven. Museums and American Intellectual Life, 1876-1926. Chicago: The University of Chicago Press, 1998.

Cooke, Edward S. "Talking or Working: The Conundrum of Moral Aesthetics I Boston's Arts and Crafts Movement. In Inspiring Reform: Boston's Arts and Crafts Movement, edited by Marilee Boyd Meyer, 17-31. New York: Harry N. Abrams, 1997. 
Corn, Wanda M. The Great American Thing. Modern Art and National Identity, 19151935. Berkeley: University of California Press, 1999.

Cotton, John Dana. “The Gloom of the Museum.” In Reinventing the Museum: Historical and Contemporary Perspectives on the Paradigm Shift, edited by Gail Anderson, 13-29. Lanham, Maryland: AltaMira Press, 2004.

Croce, Benedetto. The Essence of Aesthetic. A lecture prepared for the inauguration of the Rice Institute of Houston, Texas, in 1912. Translated by Douglas Ainslie. (London, England : W. Heinemann, 1921).

Dewey, John. Art as Experience. 1934. Reprint, New York: Penguin, 2005.

DiMaggio, Paul. "Cultural Entrepreneurship in Nineteenth-Century Boston: The Creation of an Organizational Base for High Culture in America." Media, Culture \& Society 4, no.1 (January 1982): 33-50.

—. "Progressivism and the Arts." Society 25, no. 5 (July 1988): 70-75.

Douglas, George. "A Reconsideration of the Dewey-Croce Exchange." The Journal of Aesthetics and Art Criticism 28, no.4 (Summer 1970): 497-504.

Dow, Arthur Wesley. "The Use of Pictures in Art Teaching." in the School Arts Book, edited by Henry Turner Bailey, 496-497. Boston, The Applied Arts Guild, 1908.

- Composition: A Series of Exercises in Art Structure for the Use of Students and Teachers. Garden City, New York: Doubleday, 1918.

—_ "Modernism in Art." In The American Magazine of Art (January 1917): 113116.

Duncan ,Carol. Civilizing Rituals: Inside Public Art Museums. London and New York: Routledge, 1995.

Edwards, Robert. "The Art of Work." In "The Art That is Life": The Arts \& Crafts Movement in America 1875-1920, edited by Wendy Kaplan, 223-236. Boston: Museum of Fine Arts, 1987.

Efland, Arthur D. A History of Art Education. Intellectual and Social Currents in Teaching the Visual Arts. New York and London: Teachers College Press, Columbia University, 1990.

Einreinhofer, Nancy. The American Art Museum: Elitism and Democracy. London: Leicester University Press, 1997.

Emerson, Faith. "Modern Art Hits Stumptown: Sally H. Lewis and Vanguard Exhibitions at the Portland Art Museum, 1911-1924." Master's thesis, University of Oregon, 1997.

Fox, Daniel M. Engines of Culture. Philanthropy and Art Museums. Madison: The State Historical Society of Wisconsin, 1963. 
Funk, Clayton Bart. "The Development of Professional Studio Art Training in American Higher Education, 1860-1960.” PhD. Diss., Columbia University Teachers College, 1990.

Goldstein, Carl. Teaching Art: Academies And Schools From Vasari To Albers. Cambridge, England: Cambridge University Press, 1996.

Griffin, Rachael. "Portland and Its Environs." In Art of the Pacific Northwest: From the 1930s to the Present, 1-38. Washington, D.C.: Smithsonian, 1974.

Haney, James Parton. "The Development of Art Education in the Public Schools." In Art Education in the Public Schools of the United States, edited by James Parton Haney, 22-77. New York: American Art Annual, 1908.

Harris, Neil. "The Gilded Age Reconsidered Once Again.” Archives of American Art Journal 23, no. 4. (1983): 8-18.

- Cultural Excursions: Marketing Appetites and Cultural Tastes in Modern America. Chicago: The University of Chicago Press, 1990.

Hughes, Robert. American Visions. The Epic History of Art in America. New York: Knopf, 1997.

Hull, Roger. "Region, Expression, and 'Oregon Art' - 1930-1970.” In Oregon Experience: The Art Makers. Oregon Public Broadcasting, http://www.opb.org/programs/oregonexperiencearchive/artmakers/essay.php (accessed February 26, 2009).

Iacullo, Maria Therese. "Art History in the Emergence of the Modern Humanities: How Art Museums and Academe Established Visuality in American Learning, 1865-1937.” PhD. diss., Columbia University, 1999.

Jaffee, Barbara. "Before the New Bauhaus: From Industrial Drawing to Art and Design Education in Chicago.” Design Issues 21, no. 1 (Winter 2005): 41-62.

Joki, Robert L. "The Art of The Fair. The Lewis and Clark Centennial Exposition, 1905." In Oregon Painters edited by Ginny Allen and Jody Klevit, 33-36. Portland: Oregon Historical Society Press, 1999.

Kaplan, Wendy. "The Lamp of British Precedent: An Introduction to the Arts and Crafts Movement." In "The Art That is Life": The Arts \& Crafts Movement in America 1875-1920, edited by Wendy Kaplan, 52-60. Boston: Museum of Fine Arts, 1987.

—. "Spreading the Crafts: The Role of the Schools." In "The Art That is Life": The Arts \& Crafts Movement in America 1875-1920, edited by Wendy Kaplan, 298-307. Boston: Museum of Fine Arts, 1987.

Kemp, Gary. "The Croce-Collingwood Theory as Theory." The Journal of Aesthetics and Art Criticism 61, no. 2 (Spring 2003): 171-193. 
Korzenik, Diana. Drawn to Art: A Nineteenth-Century American Dream. Hanover, New Hampshire: University Press of New England, 1985.

—_. "Introduction." In The Cultivation of Artists in Nineteenth-Century America, edited by Georgia Brady Barnhill, Diana Korzenik, and Caroline F. Sloat, 1119. Worcester, Massachusetts: American Antiquarian Society, 1997.

Kreisman, Lawrence and Glenn Mason. The Arts and Crafts Movement in the Pacific Northwest. Timber Press: Portland, Oregon, 2007.

Lansing, Jewel. Portland: People, Politics, and Power, 1851-2001. Corvallis, Oregon: Oregon State University Press, 2003.

Lears, T. J. Jackson. No Place of Grace: Antimodernism and the Transformation of American Culture, 1880-1920. New York: Pantheon Books, 1981.

Lehman, Joyce Woelfle. "Art Museum Schools: the Rise and Decline of a New Institution in Nineteenth-Century America." In The Cultivation of Artists in Nineteenth-Century America, edited by Georgia Brady Barnhill, Diana Korzenik, and Caroline F. Sloat, 207-220. Worcester, Massachusetts: American Antiquarian Society, 1997.

Levine, Lawrence W. Highbrow/Lowbrow: The Emergence of Cultural Hierarchy in America. Cambridge, Mass.: Harvard University Press, 1988.

Levy, Florence N. "Educational Work of Art Museums." In Art Education in the Public Schools of the United States, edited by James Parton Haney, 375-419. New York: American Art Annual, 1908.

Low, Theodore Lewis. The Educational Philosophy and Practice of Art Museums in the United States. 1948. Reprint, New York: AMS Press, 1972.

MacColl, E. Kimbark. The Shaping of a City. Portland, Oregon: The Georgian Company Press, 1976.

Malvern, S.B. "Inventing 'Child Art': Franz Cizek and Modernism.” In The British Journal of Aesthetics 35, no. 3 (July 1995): 262-273.

Mancini, JoAnne Marie. "One Term is as Fatuous as Another: Responses to the Armory Show Reconsidered.” In American Quarterly 51, no. 4 (December 1999): 833-870.

McCarthy, Kathleen D. Women's Culture: American Philanthropy And Art, 18301930. Chicago: University of Chicago Press, 1991.

-.'Creating the American Athens: Cities, Cultural Institutions, and the Arts, 1840-1930.” In American Quarterly 37, no. 3 (1985): 426-439.

${ }^{1}$ Merriam, Paul G. "Urban Elite in the Far West Portland, Oregon, 1870-1890." Journal of the Southwest 18, no. 1 (Spring 1976): 41-52.

Meyer, Karl E. The Art Museum: Power, Money, Ethics. New York: Morrow, 1979. 
Meyer, Marilee Boyd. "Arthur Wesley Dow and his Influence on the Arts and Crafts." In Arthur Wesley Dow, 1857-1922: His Art and His Influence, edited by Nancy E. Green, 44-75. New York: Spanierman Gallery, 1999.

Michaux, Lisa Dickinson. “A Forgotten Collector Makes His Mark: William Mead Ladd and Print Collecting at the Turn of the Century." In Twenty-FirstCentury Perspectives on Nineteenth-Century Art: Essays in Honor of Gabriel P. Weisberg, edited by Petra Ten-Doesschate Chu and Laurinda S. Dixon, 8592. Newark, Delaware: University of Delaware Press, 2008.

Morgan, H. Wayne. New Muses: Art in American Culture, 1865-1920. Norman, Oklahoma: University of Oklahoma Press, 1978.

Morrin, Peter, Judith Zilczer, and William C. Agee, eds. The Advent of Modernism: Post-impressionism and North American Art, 1900-1918. Atlanta, Georgia: High Museum of Art, 1986.

Munk, Michael. “The Diaries of Helen Lawrence Walters.” Oregon Historical Quarterly 106, no. 4 (Winter 2005): 1-25.

Niles, Philip. Beauty of the City: A.E. Doyle, Portland's Architect. Corvallis: Oregon State University Press, 2008.

Pevsner, Nikolaus. Pioneers of Modern Design. From William Morris to Walter Gropius. 1936. Reprint, New Haven, Massachusetts: Yale University Press, 2004.

—. . Academies of Art, Past and Present. Cambridge, England: Cambridge University Press, 1940.

Pohl, Frances K. A Social History of American Art. New York: Thames \& Hudson, 2002.

Sienkewicz, Julia A. "Uniting the Arts and the Academy. A History of the CAA Annual Conference." In The Eye, the Hand, the Mind: 100 Years of the College Art Association, edited by Susan Ball, 89-128. Piscataway, New Jersey: Rutgers University Press, 2010.

Singerman, Howard. Art Subjects. Berkeley: University of California Press, 1999.

Smith, Peter. The History of American Art Education: Learning about Art in American Schools. Westport, Conn.: Greenwood, 1996

Smith, Richard Cándida. "The Elusive Quest of the Moderns.” In On the Edge of America. California Modernist Art, 1900-1950, edited by Paul J. Karlstrom 2138. Berkeley: University of California Press, 1996.

Soucy, Donald. "A History of Art Education Histories.” In Framing the Past: Essays on Art Education, edited by Donald Soucy and Mary Ann Stankiewicz. 3-31. Reston, Virginia: National Art Education Association, 1990. 
Spiess, Philip D. "Toward a New Professionalism: American Museums in the 1920s and 1930s." Museum News 75, no. 2 (1996.): 38-47.

Stankiewicz, Mary Ann. “'The Eye Is a Nobler Organ': Ruskin and American Art Education.” Journal of Aesthetic Education 18, no. 2 (Summer, 1984): 51-64.

- "A Picture Age: Reproductions in Picture Study." Studies in Art Education 26, no. 2 (Winter, 1985): 86-92.

—. "Form, Truth and Emotion.” Journal of Art \& Design Education 7, no. 1 (1988): 81-95.

—. "From the Aesthetic Movement to the Arts and Crafts Movement." Studies in Art Education 33, no.3 (Spring, 1992): 165-173.

Roots of Art Education Practice. Worcester, Massachusetts: Davis Publications, 2001

Stansky, Peter. Redesigning the World: William Morris, the 1880s, and the Arts and Crafts. New Jersey: Princeton University Press, 1985.

Steffensen-Bruce, Ingrid A. Marble Palaces, Temples of Art: Art Museums, Architecture, and American Culture, 1890-1930. Lewisburg, Pennsylvania: Bucknell University Press, 1998.

Stein, Roger B.. John Ruskin and Aesthetic Thought in America, 1840-1900. Cambridge, Massachusetts: Harvard University Press, 1967.

Steiner, Raymond J. The Arts Students League of New York: A History. Saugerties, New York: CSS Publications, 1999.

Stocking , George W., Jr. 'On the Limits of 'Presentism' and 'Historicism' in the Historiography of the Behaviroal Sciences.” In Race, Culture \& Evolution: Essays in the History of Anthropology, edited by George W. Stocking Jr., 112. New York: The Free Press, 1968.

Sussman, Warren. Culture As History: The Transformation of American Society in the Twentieth Century. New York: Pantheon Books, 1984.

Taylor, Joshua C. The Fine Arts in America. Chicago: University of Chicago Press, 1979.

—_. "Introduction." In Art of the Pacific Northwest: From the 1930s to the Present, XI-XII. Washington, D.C.: Smithsonian, 1974.

Trachtenberg, Alan. The Incorporation of America. Culture And Society in the Gilded Age. New York: Hill and Wang, 1982.

Wallach, Alan. "The American Cast Museum: An Episode in the History of the Institutional Definition of Art." In Exhibiting Contradiction: Essays on the Art Museum in the United States, edited by Alan Wallach, 38-56. Amherst, Massachusetts: University of Massachusetts Press, 1998. 
Weitenkampf, Frank. "The Museum and the Small Library." Art and Progress 4, (November 1912-October 1913): 1069-1072.

Wilmer. Clive. "Introduction." In Unto This Last and other Writings by John Ruskin, edited by Clive Wilmer, 7-37. London, England: Penguin, 1997.

Wilson, Brent, ed. The History of Art Education: Proceedings from the Second Penn State Conference, 1985. Reston, Virginia: National Art Education Association, 1985.

Wilson, William H. The City Beautiful Movement. Baltimore: Johns Hopkins University Press, 1989.

Wygant, Foster. "Foreword." In Framing the Past: Essays on Art Education, edited by Donald Soucy and Mary Ann Stankiewicz. ix-xii. Reston, Virginia: National Art Education Association, 1990.

- School Art in American Culture 1820-1970. Cincinnati, Ohio: Interwood, 1993. 